\title{
Strontium-90 at the Hanford Site and its Ecological Implications
}

\author{
R. E. Peterson \\ T. M. Poston
}

May 2000

Prepared for the U.S. Department of Energy under Contract DE-AC06-76RLO 1830 


\title{
DISCLAIMER
}

This report was prepared as an account of work sponsored by an agency of the United States Government. Neither the United States Government nor any agency thereof, nor Battelle Memorial Institute, nor any of their employees, makes any warranty, express or implied, or assumes any legal liability or responsibility for the accuracy, completeness, or usefulness of any information, apparatus, product, or process disclosed, or represents that its use would not infringe privately owned rights. Reference herein to any specific commercial product, process, or service by trade name, trademark, manufacturer, or otherwise does not necessarily constitute or imply its endorsement, recommendation, or favoring by the United States Government or any agency thereof, or Battelle Memorial Institute. The views and opinions of authors expressed herein do not necessarily state or reflect those of the United States Government or any agency thereof.

\author{
PACIFIC NORTHWEST NATIONAL LABORATORY \\ operated by \\ BATTELLE \\ for the \\ UNITED STATES DEPARTMENT OF ENERGY \\ under Contract DE-ACO6-76RLO 1830
}

\author{
Printed in the United States of America \\ Available to DOE and DOE contractors from the \\ Office of Scientific and Technical Information, P.O. Box 62, Oak Ridge, TN 37831; \\ prices available from (615) 576-8401. \\ Available to the public from the National Technical Information Service, \\ U.S. Department of Commerce, 5285 Port Royal Rd., Springfield, VA 22161
}

(3) This document was printed on recycled paper. 


\title{
Strontium-90 at the Hanford Site and its Ecological Implications
}

\author{
R. E. Peterson \\ T. M. Poston
}

May 2000

Prepared for

the U.S. Department of Energy

under Contract DE-AC06-76RLO 1830

Pacific Northwest National Laboratory

Richland, Washington 99352 


\section{Executive Summary}

Strontium-90, a radioactive contaminant from historical operations at the U.S. Department of Energy (DOE) Hanford Site, enters the Columbia River at several locations associated with former plutonium production reactors at the Site. Strontium-90 is of concern to humans and the environment because of its moderately long half-life (29.1 years), its potential for concentrating in bone tissue, and its relatively high energy of beta decay.

Although strontium-90 in the environment is not a new issue for the Hanford Site, recent studies of near-river vegetation along the shoreline near the 100 Areas raised public concern about the possibility of strontium-90-contaminated groundwater reaching the riverbed and fall chinook salmon redds. This report describes Hanford Site sources of strontium-90, its distribution in groundwater, how and where it enters the river, and its potential ecological impacts. The report characterizes groundwater contaminants in the near-shore environment and assesses the potential for ecological impact using one of the most sensitive ecological indicators for aquatic organisms - salmon embryos. Major findings of this report are summarized below.

Strontium-90 was produced by nuclear fission in fuel elements used in plutonium production reactors. Various waste streams were created by past Hanford operations that contained strontium-90. In the 100 Areas near the river, some of these wastes were discharged to the soil column via engineered disposal facilities such as cribs and trenches. Residual amounts of strontium-90 from these discharges remain in the soil column and groundwater. Additional amounts of strontium- 90 are contained in wastes stored in the 200 Areas facilities (underground tanks), in the 100-K fuel storage basins, and in the soil column beneath former waste disposal sites in the 100 and 200 Areas. No current facility operations result in discharge of strontium-90 to the environment.

Information on the distribution of strontium-90 in groundwater and the Hanford Site environment is readily available to the public through DOE Reading Rooms and from web sites. Information on strontium-90 contamination in groundwater has been disseminated to the public through annual groundwater monitoring reports and annual environmental surveillance reports. Additional, highly detailed reports are available from the Hanford Technical Library on strontium-90 investigations at the 100-N Area associated with an expedited response action being conducted under CERCLA.

Strontium-90 exceeds the U.S. Environmental Protection Agency (EPA) drinking water standard for groundwater $(8 \mathrm{pCi} / \mathrm{L})$ at multiple locations in the vicinity of the reactor areas (100 Area). At the 100-N Area, strontium-90 is present in the aquifer near the river and within the rooting zone of shoreline vegetation. At near-river sites, the EPA drinking water standard for strontium-90 is exceeded in groundwater at locations near former reactor coolant retention basins and liquid waste disposal trenches. The maximum concentrations at most reactor areas are typically less than $50 \mathrm{pCi} / \mathrm{L}$, and contamination is restricted to relatively small areas. At the 100-N Area, the drinking water standard is greatly exceeded in groundwater. Relatively high concentrations are observed in wells, riverbank seepage, and at other sampling 
sites very near the river. Because this area has the highest concentrations of strontium-90, an expedited response action is in progress to reduce the movement of groundwater to the river by using pump-andtreat methodology.

The EPA drinking water standard for strontium-90 is predicated on exposure to a 150-pound human drinking $2 \mathrm{~L}$ of water per day for 1 year. This standard is not applicable to aquatic organisms. However, the Washington State Department of Ecology has adopted the 8-pCi/L drinking water standard as an ambient water quality standard for freshwater. Adoption of drinking water standards for ambient water quality standards is grounded in the assumption that levels assessed as safe for human consumption with the attendant "margins of safety" will also ensure protection of the environment. The drinking water standard is designed to protect the most susceptible individuals, whereas dose-based standards for aquatic organisms are based on protecting populations of organisms.

The standard for aquatic organisms for protection from radiation exposure is $1.0 \mathrm{rad} / \mathrm{day}$, which is much greater than dose rates estimated for the river substrate at the $100-\mathrm{H}$ Area $(0.000021 \mathrm{rad} / \mathrm{day})$. The estimated doses from all radionuclides to salmon embryos-sac fry at the 100-H Area are well below the $1.0 \mathrm{rad} /$ day standard. Suppression of the immune response in rainbow trout at $0.2 \mathrm{rad} /$ day is the most sensitive biological endpoint documented for fish in a laboratory experiment. However, the conditions of the study and the response of the exposed organisms have little ecological significance.

Of the 10 main fall chinook salmon spawning areas in the Hanford Reach, only the spawning grounds near Locke Island (opposite the 100-H Area) appear to be potentially influenced by the upwelling of Hanford Site groundwater, which may contain contaminants. The majority of redds are located outside the presumed area of influence of Hanford contaminant plumes. Salmon eggs and fry exposed in the river bottom environment would not accumulate strontium-90 until calcified tissue is being formed. This occurs late in the intragravel development stage, thus further limiting the time window for exposure to potentially contaminated groundwater that passes through the spawning gravel. The opportunity for the juvenile organism to accumulate strontium- 90 is therefore very limited with respect to time, as well as to areas where contaminated groundwater might be encountered.

Several risk assessments conducted since 1991 evaluated the potential risk of strontium-90 entering the Columbia River. All assessments concluded that the risk was within or well-below established guidelines. The very small number of salmon redds exposed, along with the low dose associated with that exposure (about 50,000 times lower than the $1.0 \mathrm{rad} /$ day limit), indicate that the exposure conditions at the 100-H Area do not constitute an unacceptable risk to salmon spawning at 100-H Area. Current knowledge of Hanford Site groundwater contamination, groundwater movement, and the locations for spawning in the Hanford Reach, all suggest that this conclusion generally applies to the entire Hanford Reach. 


\section{Acknowledgments}

The authors are grateful to K. Mike Thompson and Dana C. Ward (U.S. Department of Energy) for their encouragement to develop what started as an internal briefing memorandum into a comprehensive report intended for a wide audience. Extensive suggestions and comments on the original briefing report were provided by Katy Makeig (Waste Science, Inc.) to whom the authors extend their gratitude.

David R. Geist and Charles R. Brandt (Pacific Northwest National Laboratory) provided significant contributions to the sections that discuss fall chinook salmon and their habitat in the Hanford Reach. A significant amount of information generated by the Environmental Restoration Contractor team (Bechtel Hanford, Inc. and CH2M HILL Hanford, Inc.) has been incorporated into the section that describes strontium-90 in groundwater and into Appendices A and B. The authors would like to acknowledge the efforts of those who were involved in that work.

Mary J. Hartman and Roger L. Dirkes (PNNL) reviewed the report and offered suggestions that improved the final version. Georganne O'Connor provided considerable editorial assistance in converting the original briefing materials into a readable and consistent format. Chris A. Newbill (PNNL) created the strontium-90 maps, and Lila M. Andor (PNNL) compiled the text and figures for this report. The report was prepared under the auspices of the Public Safety and Resource Protection Program and the Hanford Groundwater Monitoring Project. 


\section{Contents}

Executive Summary ...................................................................................................

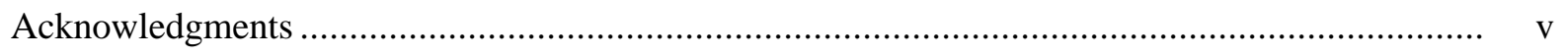

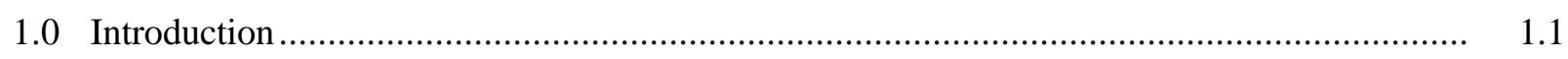

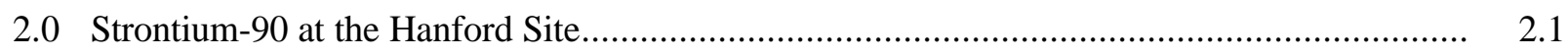

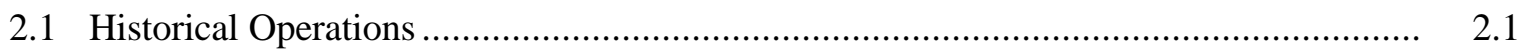

2.1.1 100 Area Production Reactors …........................................................ 2.2

2.1.2 200 Areas Chemical Processing Facilities................................................... 2.4

2.1.3 300 Area Fuel Element Fabrication Facilities................................................ 2.4

2.1.4 Residual Contamination ...................................................................... 2.4

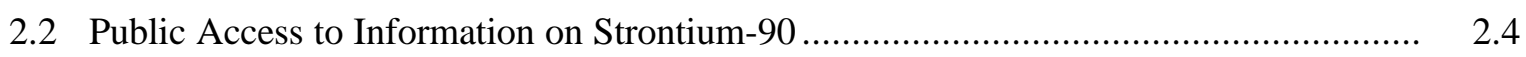

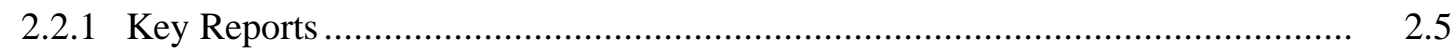

2.2.2 Internet Web Sites ............................................................................. 2.5

2.2.3 Data Repository: Hanford Environmental Information System......................... 2.6

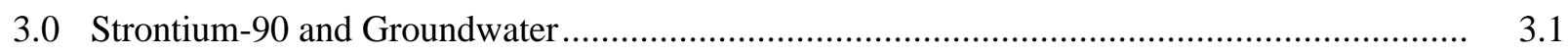

3.1 Extent of Strontium-90 Contamination ............................................................. 3.1

3.1 .1 Current Conditions ....................................................................... 3.1

3.1.2 Potential Future Conditions …............................................................. 3.25

3.2 Groundwater Remediation Activities ................................................................. 3.26

3.2.1 100-N Pump-and-Treat System ................................................................. 3.26

3.2.2 Other Groundwater Remediation Activities ............................................ 3.27

4.0 Strontium-90 and Fall Chinook Salmon .....................................................................

4.1 Occurrence/Distribution in Redds of the Hanford Reach ......................................... 4.1

4.1.1 History of Spawning in the Reach........................................................... 4.1

4.1.2 Spawning Areas and Groundwater Contamination ....................................... 4.3

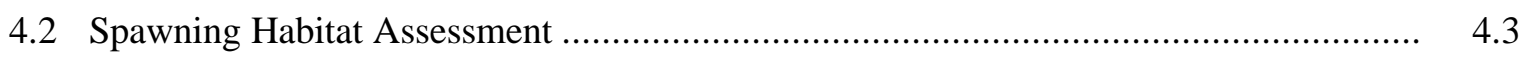

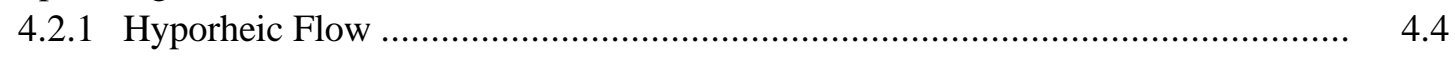

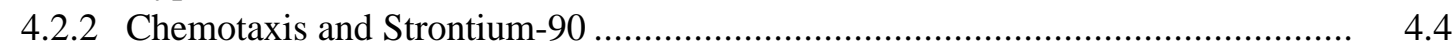

4.2.3 Aquatic Fate/Behavior of Strontium-90 .................................................. 4.5

4.2.4 Developmental Considerations ................................................................ 4.6

4.2.5 Immersion Dose Rates.................................................................... 4.7 


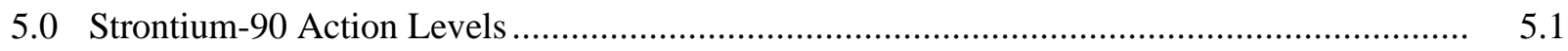

5.1 Applicable Standards and Measurements ............................................................ 5.1

5.1 .1 Aquatic Organism Dose Limit ................................................................ 5.1

5.1.2 EPA Drinking Water Standard/State of Washington Ambient Water

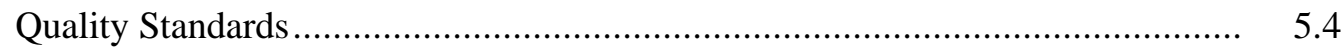

$5.1 .3 \quad$ 100-N Area Special Study ….................................................................... 5.4

5.2 Risk Assessments and Decisions ................................................................... 5.4

5.2.1 CRCIA Risk Assessment........................................................................... 5.5

5.2.2 Limited Field Investigations .................................................................. 5.5

5.2.3 100-N Expedited Response Action ......................................................... 5.7

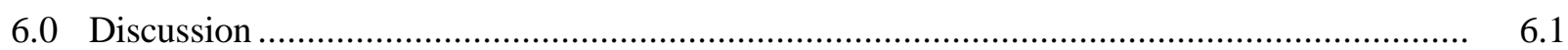

6.1 Residual Contamination and Potential Future Sources.............................................. 6.1

6.2 Estimate of Environmental Dose to Salmon ........................................................ 6.2

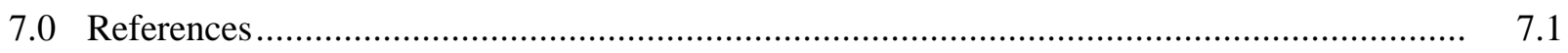

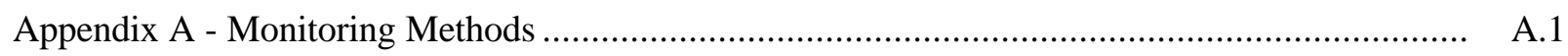

Appendix B - Uncertainties Associated With Plume Characterization.................................. B.1

Appendix C - Overview of Studies on Immuno-Suppression and Exposure to Tritium................. C.1 


\section{Figures}

1.1 General Location Map of the Hanford Site.

2.1 Aerial Photograph of 100-K During Operations, 1955-1971 …...................................... 2.3

3.1 Distribution of Radionuclides in Groundwater at the Hanford Site ................................. 3.2

3.2 Distribution of Strontium-90 in 100-B/C Area Groundwater, 1999 ................................... 3.4

3.3 Distribution of Strontium-90 in 100-K Area Groundwater, 1999 ................................ 3.7

3.4 Distribution of Strontium-90 in 100-N Area Groundwater, 1999 .................................. 3.10

3.5 Distribution of Strontium-90 in 100-D/DR Area Groundwater, 1999 ............................. 3.15

3.6 Distribution of Strontium-90 in 100-H Area Groundwater, 1999 ................................... 3.18

3.7 Distribution of Strontium-90 in 100-F Area Groundwater, 1999 ................................... 3.21

4.1 Major Fall Chinook Salmon Spawning Areas in the Hanford Reach............................... 4.2

4.2 Salmon Redd Counts at Vernita Bar, 100-D, 100-H, and Ringold/Wooded Island

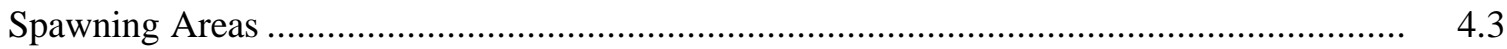

4.3 Conceptual Model for Hyporheic Flow in Hanford Reach Sediments ............................. 4.5

4.4 Development of Salmon at 9.5 Degrees Celsius ..................................................... 4.8

5.1 Total Radiation Dose and Effects in Fish .............................................................. 5.2

6.1 Reference Dose Rates and Modeled Dose Rates ............................................................ 


\section{Tables}

2.1 Chronology of Recent Key Reports Regarding Strontium-90 and Potential Impact to the River

3.1 Summary of Strontium-90 and Gross Beta Concentrations in 100-B/C Area Wells, 1995 to 2000 .

3.2 Summary of Strontium-90 and Gross Beta Concentrations in 100-K Area Wells, 1995 to 2000 .

3.3 Summary of Strontium-90 and Gross Beta Concentrations in 100-N Area Wells, 1995 to 2000 .

3.4 Summary of Strontium-90 and Gross Beta Concentrations in 100-D/DR Area Wells, 1995 to 2000

3.5 Summary of Strontium-90 and Gross Beta Concentrations in 100-H Area Wells, 1995 to 2000 .

3.6 Chromium and Strontium-90 Results for Riverbed Pore Water, 100-H Area

3.7 Summary of Strontium-90 and Gross Beta Concentrations in 100-F Area Wells, 1995 to 2000 .

3.8 Summary of Strontium-90 and Gross Beta Concentrations in 300 Area Wells, 1995 to 2000 .

5.1 Results of Qualitative Risk Assessments Performed as Part of the Limited Field Investigations under CERCLA, 1991-1994. 


\subsection{Introduction}

Strontium-90, a radioactive contaminant from historical operations at the U.S. Department of Energy (DOE) Hanford Site (Figure 1.1), enters the Columbia River at several locations associated with former plutonium production reactors at the Site. Strontium-90 is of concern to humans and the environment because of its moderately long half-life (29.1 years), its potential for concentrating in bone tissue, and its relatively high energy of beta decay.

Although strontium-90 in the environment is not a new issue for the Hanford Site, recent studies of near-river vegetation along the shoreline near the 100 Areas raised public concern about the possibility of strontium-90-contaminated groundwater reaching the riverbed and fall chinook salmon redds. To address these concerns, DOE asked Pacific Northwest National Laboratory (PNNL) to prepare this report on strontium-90, its distribution in groundwater, how and where it enters the river, and its potential ecological impacts, particularly with respect to fall chinook salmon.

The purpose of the report is to characterize groundwater contaminants in the near-shore environment and to assess the potential for ecological impact using salmon embryos, one of the most sensitive ecological indicators for aquatic organisms.

Section 2.0 of the report provides background information on strontium-90 at the Hanford Site related to historical operations. Public access to information on strontium-90 also is described. Section 3.0 focuses on key issues associated with strontium-90 contamination in groundwater that discharges in the Hanford Reach. The occurrence and distribution of fall chinook salmon redds in the Hanford Reach and characteristics of salmon spawning are described in Section 4.0. Section 5.0 describes the regulatory standards and criteria used to set action levels for strontium-90. Recommendations for initiating additional monitoring and remedial action associated with strontium- 90 contamination at the Hanford Site are presented in Section 6.0. Appendix A describes monitoring methods. Appendix B discusses uncertainties associated with plume characterizations, and Appendix $\mathrm{C}$ provides an overview of studies on fish immuno-suppression and exposure to tritium. 
Title:

G99030045-2.eps

Creator:

FreeHand 8.0

Preview:

This EPS picture was not saved

with a preview included in it.

Comment:

This EPS picture will print to a

PostScript printer, but not to

other types of printers.

Figure 1.1. General Location Map of the Hanford Site (from Dirkes et al. 1999) 


\subsection{Strontium-90 at the Hanford Site}

Strontium-90 is a fission product associated with fuel elements used in the Hanford Site's former plutonium production reactors, which are located in the 100 Area of the Site (see Figure 1.1). In past operations, fuel elements in the reactors periodically ruptured, releasing strontium-90 into the reactor coolant water. The radionuclide was also released to fuel storage basin shielding water when damaged fuel elements were placed in the basins.

Because strontium-90 contamination in the Hanford environment is primarily located in the vadose zone and groundwater beneath the 100 Areas, this section of the report focuses on those areas. However, strontium-90 also was present in the variety of waste streams associated with chemical processing of irradiated fuel rods in the 200 Area. Significant inventories of strontium- 90 currently exist in the highlevel radioactive waste stored in underground tanks in the 200 Area, in the vadose zone beneath disposal sites, and as strontium and cesium capsules prepared for industrial/medical uses. In addition, a background amount of strontium-90 is present in the Hanford environment that is the result of atmospheric fallout from historical above-ground nuclear weapons testing.

Descriptions of reactor operations at the various waste sites that have resulted over the last 50 years are included in a series of technical baseline reports prepared by DOE's Environmental Restoration Contractor. The following reports provide detailed information on sources of strontium-90 and other contaminants that have been released to the environment in the 100 Areas:

$\begin{array}{ll}\text { 100-B/C Area } & \text { (Carpenter et al. 1994) } \\ \text { 100-KE/KW Area } & \text { (Carpenter and Cotè 1994) } \\ \text { 100-N Area } & \text { (Cotè 1994) } \\ \text { 100-D/DR Area } & \text { (Carpenter 1993) } \\ \text { 100-H Area } & \text { (Deford and Einan 1995) } \\ \text { 100-F Area } & \text { (Deford 1993). }\end{array}$

Information provided in the following subsections comes primarily from these reports, unless otherwise cited.

\subsection{Historical Operations}

Nine reactors were constructed along the Hanford Reach of the Columbia River between 1943 and 1963. The principal production years were during the Cold War period, approximately 1950 through 1965 , although several reactors continued operating slightly longer. Strontium- 90 was created by fission of uranium-238 in the reactor fuel elements and became a constituent in liquid effluent waste streams that were disposed to the environment. The following paragraphs summarize operations that are relevant to strontium-90 in the environment. 


\subsubsection{Area Production Reactors}

At the reactor areas along the Columbia River, liquid effluents containing radionuclides would typically be disposed to soil column facilities of various design. Relatively small volume discharges from the coolant cycle, test facilities, and the fuel storage basins would go to cribs, "French drains," and percolation ponds, at sites located near the reactor buildings. These disposal facilities typically consisted of excavations with surface areas on the order of 10 square meters or less and contained coarse gravel fill to enhance infiltration rates. Large volume discharges of highly radioactive effluent were disposed in liquid waste disposal trenches, which covered a much greater surface area and were located near the river. These trenches were specifically designed for infiltration of large volumes of effluent. Their design acknowledged the radionuclide retardation properties of Hanford sediments, which would presumably sequester the radionuclide in the sediment.

For the original eight production reactors, large volumes of reactor coolant that had passed through the reactor core during normal operations were directed to retention basins. Because of the thermal shock associated with the near-boiling, used coolant, the underground pipelines and retention basins developed leaks. The leakage was sufficient to create mounds on the underlying groundwater table (Brown 1963). The mounding created a radial flow pattern, causing coolant contaminants (primarily short-lived radionuclides and dissolved chromium) to spread widely throughout the reactor area. The mounding also caused accelerated groundwater movement toward the river, as well as increased riverbank seepage. After the reactors stopped operating, these mounds dissipated, leaving residual amounts of contamination in the now unsaturated portion of the soil column.

Occasionally, fuel elements would rupture, causing increased radionuclide contamination of the reactor coolant. When this occurred, the coolant was diverted from its normal course (i.e., through the retention basins and into the river via outfall pipes) to a liquid waste disposal trench. The largest such trench is located at the 100-K Area and is referred to as the "100-K Mile Long Trench" (Figure 2.1). The soil column beneath the liquid waste disposal trenches at each of the original eight production reactors contains strontium-90 and other radionuclides.

The reactor cooling system for the $100-\mathrm{N}$ reactor was different than for the eight original production reactors. Instead of a single pass of coolant through the reactor, the 100-N reactor had a semiclosed-loop cooling system, which allowed a greater buildup of radionuclides in the coolant than did single-pass reactors. Normal operation included bleed off and leakage that was routed to the 1301-N crib/trench disposal facility, which started operation in 1963. Also, a significant quantity of primary coolant was discharged to the fuel storage basin during fuel element change out. The fuel storage basin shielding water was ultimately discharged to the 1301-N facility. The fuel storage basin operated in a single-pass shielding water mode for part of its history, with the effluent being routed to the 1301-N and 1325-N facilities; the latter facility came into service in 1983. Effluents from the primary coolant system and from the fuel storage basin contained significant quantities of strontium-90. 


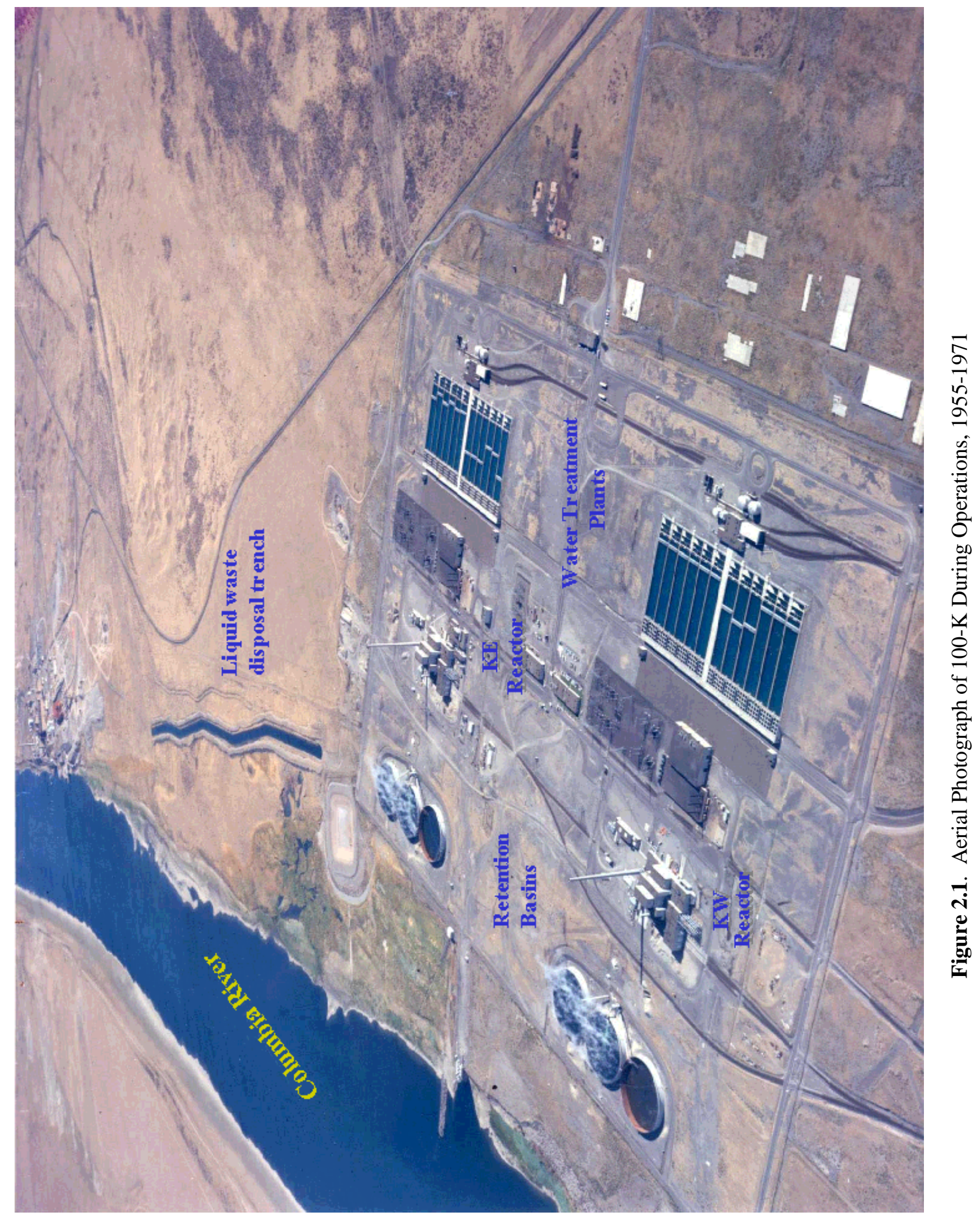




\subsubsection{Areas Chemical Processing Facilities}

Strontium-90 was present in large amounts in the waste streams associated with fuel element processing in the 200 Areas. The wastes ended up in either high-level radioactive waste underground tanks or was disposed to the soil column via cribs, trenches, and ponds. Although a large inventory of strontium-90 is present in the various waste forms in the 200 Areas, only a small portion of this inventory appears to have reached groundwater. One prominent site is the 216-B-5 injection well (Hartman 1999, p. 5.92), which was used for intentional disposal of wastes to the subsurface. No strontium- 90 from 200 Areas' sources is known to have reached the Columbia River via the groundwater pathway.

\subsubsection{Area Fuel Element Fabrication Facilities}

Strontium-90 was not common in significant quantities in the 300 Area, which was originally used to fabricate fuel elements for the production reactors. Following the production years, facilities in the 300 Area were used for research involving fuel elements. Although detected in groundwater at several locations, the maximum concentration observed in recent years is $8.7 \mathrm{pCi} / \mathrm{L}$, which is close to the U.S. Environmental Protection Agency (EPA) drinking water standard of $8 \mathrm{pCi} / \mathrm{L}$. The source for this strontium has not yet been clearly identified, but it is likely to be related to research activities associated with irradiated fuel elements. Strontium-90 was not detected in riverbank seepage samples (DOE-RL 1994a, p. A.8; Dirkes et al. 1999, p. A.11) or in sediments along the 300 Area shoreline at concentrations exceeding levels measured upstream of Hanford at Priest Rapids (DOE-RL 1994a, p. A.14; Dirkes et al. 1999, p. A.6-A.8).

\subsubsection{Residual Contamination}

Two key ramifications of groundwater mounding beneath the 100 Areas retention basins are 1) mounds created a radial flow pattern with steep gradients, and 2) contaminated effluent was dispersed through areas of normally unsaturated sediment. The implication of radial flow is that the principal contaminants associated with reactor coolant, i.e., short-lived radionuclides and hexavalent chromium, were widely dispersed throughout groundwater in the reactor area. Some long-lived radionuclides, such as strontium-90, were included in this flow, although their dispersion would have been less than that for chromium because of adsorption onto soil particles. The implication of contaminated effluent in the normally unsaturated sediment of the vadose zone is that it remained behind (i.e., adsorbed to sediment) after the supply stopped and the mounds dissipated. The residual contamination might act as a continuing local source, given increased infiltration of surface moisture from precipitation or human activities.

\subsection{Public Access to Information on Strontium-90}

The DOE makes information on environmental conditions at the Hanford Site available through a variety of media, including electronic and paper copy versions. Key reports are distributed to libraries and city/county governments in communities around the Hanford Site and to several university libraries in Washington and Oregon. Copies also can be found at DOE's Hanford Reading Room, located in the Consolidated Information Center on the campus of Washington State University at Tri-Cities. The DOE Hanford Reading Room can be accessed on the Internet at www.hanford.gov/doe/reading.htm. Their 
catalog is available at http://rrcatalog.pnl.gov. Other DOE public reading rooms in the Northwest are located at the Bonneville Power Administration building, 905 Northeast $11^{\text {th }}$ Avenue, in Portland Oregon, and at the DOE Idaho Operations Office, 1776 Science Center Drive, Idaho Falls, Idaho. Copies of DOE reports can be purchased from the National Technical Information Service, U.S. Department of Commerce, 5285 Port Royal Road, Springfield Virginia 22161.

\subsubsection{Key Reports}

Pacific Northwest National Laboratory prepares two reports annually that provide detailed current information on strontium-90 in the environment:

- Hanford Site Groundwater Monitoring (e.g., Hartman et al. 2000). This report describes current groundwater conditions associated with various geographic scales on the Site. The descriptions summarize historical operations that resulted in groundwater contamination, the waste sites involved, and results of recent monitoring activities. The DOE releases this report to the public by March 1 each year.

- Hanford Site Environmental Report (e.g., Dirkes et al. 1999). This report presents the results of comprehensive environmental monitoring, including a summary of groundwater monitoring. It includes environmental monitoring results for the Columbia River, riverbank seepage, river sediment, air, and biota, as well as dose estimates to offsite receptors. The DOE releases this report to the public by September 30 each year.

- Hanford Site Near-Facility Environmental Monitoring Data Report (Perkins et al. 1999). This report summarizes effluent and facility monitoring at the Site. The DOE releases this report to the public by June 30 each year.

Table 2.1 provides a chronology of other key reports related to strontium-90 near the Columbia River. In addition to these documents, DOE prepares a report annually that describes the performance of the pump-and-treat system at the 100-N Area. The most recent performance evaluation is contained in the Fiscal Year 1998 Annual Summary Report for the 200-UP-1, 200-ZP-2, and 100-NR-2 Pump-and-Treat Operations and Operable Units (DOE-RL 1999a). A semiannual update to this report is contained in an Environmental Restoration Program technical memorandum.

\subsubsection{Internet Web Sites}

The DOE web site (www.hanford.gov) provides general information about the Hanford Site in addition to links to other web sites that provide more detailed information on specific aspects of Hanford Site activities, such as groundwater monitoring and environmental restoration. Specific web sites that provide public access to groundwater information for the Hanford Site are listed below:

- Hanford Site Groundwater Monitoring for Fiscal Year 1999 (Hartman et al. 2000)— http://hanford.pnl.gov/groundwater. 
- Hanford Site Environmental Report for Calendar Year 1998 (Dirkes et al. 1999)— http://hanford.pnl.gov/envreport or http://hanford.pnl.gov/envreport/1998.

- 100 K Reactor Area (Hanford Groundwater Monitoring Project)—http://pnl45.pnl.gov/100K. Also available through hanford.pnl.gov/groundwater.

\subsubsection{Data Repository: Hanford Environmental Information System}

The Hanford Environmental Information System (HEIS) is an electronic data base management system that contains analytical results for environmental samples collected from a variety of media, such as groundwater, surface water, soils, and biota. Information on the HEIS is available at: http://www.bhi.erc.com.

Table 2.1. Chronology of Recent Key Reports Regarding Strontium-90 and Potential Impact to the River

\begin{tabular}{||c|l|l||}
\hline \hline Year & \multicolumn{1}{|c||}{ Report } & \multicolumn{1}{c||}{ Comments } \\
\hline \hline 1981 & $\begin{array}{l}\text { Environmental Surveillance at Hanford for } \\
\text { CY } 1981 \text { (Sula et al. 1982) }\end{array}$ & $\begin{array}{l}\text { First publicly available report indicating that Hanford } \\
\text { Site groundwater was contaminated and was entering } \\
\text { the Columbia River (p. 23). }\end{array}$ \\
\hline 1992 & $\begin{array}{l}\text { Scoping Assessment of Radiological Doses to } \\
\text { Aquatic Organisms and Wildlife - N Springs } \\
\text { (Poston and Soldat 1992) }\end{array}$ & $\begin{array}{l}\text { Initial conservative dose assessment for terrestrial } \\
\text { and aquatic life at 100-N Area. Maximum dose to } \\
\text { carp was 0.02 rad/d exposed to 100\% spring water } \\
\text { (p. 7). }\end{array}$ \\
\hline 1997 & $\begin{array}{l}\text { Survey of Radiological Contaminants in the } \\
\text { Near-Shore Environment at the Hanford Site } \\
\text { 100-N Reactor Area } \text { (Van Verst et al. 1998) }\end{array}$ & $\begin{array}{l}\text { Comprehensive microhabitat investigation of expo- } \\
\text { sure and risk at 100-N Springs Area. Maximum } \\
\text { estimated dose to fish was 0.0014 rad/day (p. 6.3). } \\
\text { Dose was dominated by strontium-90. }\end{array}$ \\
\hline \multirow{10}{*}{$1996-98$} & $\begin{array}{l}\text { Screening Assessment and Requirements for a } \\
\text { Comprehensive Assessment, Columbia River } \\
\text { Comprehensive Impact Assessment (DOE-RL } \\
\text { 1998a) }\end{array}$ & $\begin{array}{l}\text { No life stage of salmon or steelhead was found to be } \\
\text { at risk from strontium-90 in groundwater, seeps, } \\
\text { or sediment; no prey of these or other species at } \\
\text { 100-H were found to be at risk from strontium-90. } \\
\text { Strontium-90 at the 100-N springs was identified as } \\
\text { a potential "temporary or spatially limited hot spot" } \\
\text { risk above the levels associated with the upstream } \\
\text { control segment (pp. I-4.79). }\end{array}$ \\
\hline
\end{tabular}




\subsection{Strontium-90 and Groundwater}

This section describes key issues associated with strontium-90 contamination in groundwater that approaches and discharges into the Hanford Reach of the Columbia River. A summary of current conditions at each operational area (see Figure 1.1) is presented.

Contaminant plumes in groundwater are monitored using several methods at a variety of locations. For example, the aquifer is sampled via monitoring wells completed at various depths, and near the river via aquifer sampling tubes. The zone of groundwater/river interaction is monitored using aquifer sampling tubes, riverbank seepage sites, and riverbed pore water sample sites. The movement of contamination by biological transport is monitored by collecting plant and animal samples from along and within the river. More detailed descriptions of these environmental monitoring methods are presented in Appendix A.

\subsection{Extent of Strontium-90 Contamination}

Figure 3.1 shows the distribution of strontium-90 in groundwater across the Hanford Site. As the figure shows, strontium-90 exceeds the drinking water standard near the river only in the 100 Areas. The highest concentrations are found in the plume at the 100-N Area, where an expedited response action under CERCLA is in progress to reduce contaminant movement into the river. There is no evidence that strontium-90 from sources in the 200 Areas, 300 Area, or 400 Area has reached the river.

Maps showing the geographic distribution of strontium-90 and/or gross beta activity have been produced periodically since the start of formal environmental reporting programs in the 1980s (e.g., Sula et al. 1982). Currently, information on strontium-90 contamination in groundwater and its implications with regard to the environment and human health are presented in the annual Hanford Site Environmental Report for Calendar Year 1998 (Dirkes et al. 1999). More detailed technical information on strontium-90 in groundwater is presented in the Hanford Groundwater Monitoring Project's annual report (Hartman et al. 2000). Additional maps are periodically produced to help evaluate the performance of the pump-and-treat system being used in the 100-N Area (DOE-RL 1999a, pp. 4.39 to 4.40). Most data available to describe the extent of strontium-90 pertain to the horizontal distribution are based on samples from wells that monitor conditions near the water table. Limited information is available to describe the vertical distribution within the contaminated aquifer.

\subsubsection{Current Conditions}

The following subsections describe strontium-90 contamination in groundwater for each reactor area in the 100 Areas. Results for samples from monitoring wells, aquifer sampling tubes located near the river shoreline, and riverbank seepage are described. Aquifer sampling tubes are small-diameter tubes implanted in the aquifer at multiple depths. They are located near the low-stage shoreline at approximately $600 \mathrm{~m}$ intervals between the 100-B/C Area and the Old Hanford Townsite (Peterson et al. 1998a). They provide a monitoring opportunity that is located as close as logistically possible to sites of groundwater discharge to the river. 


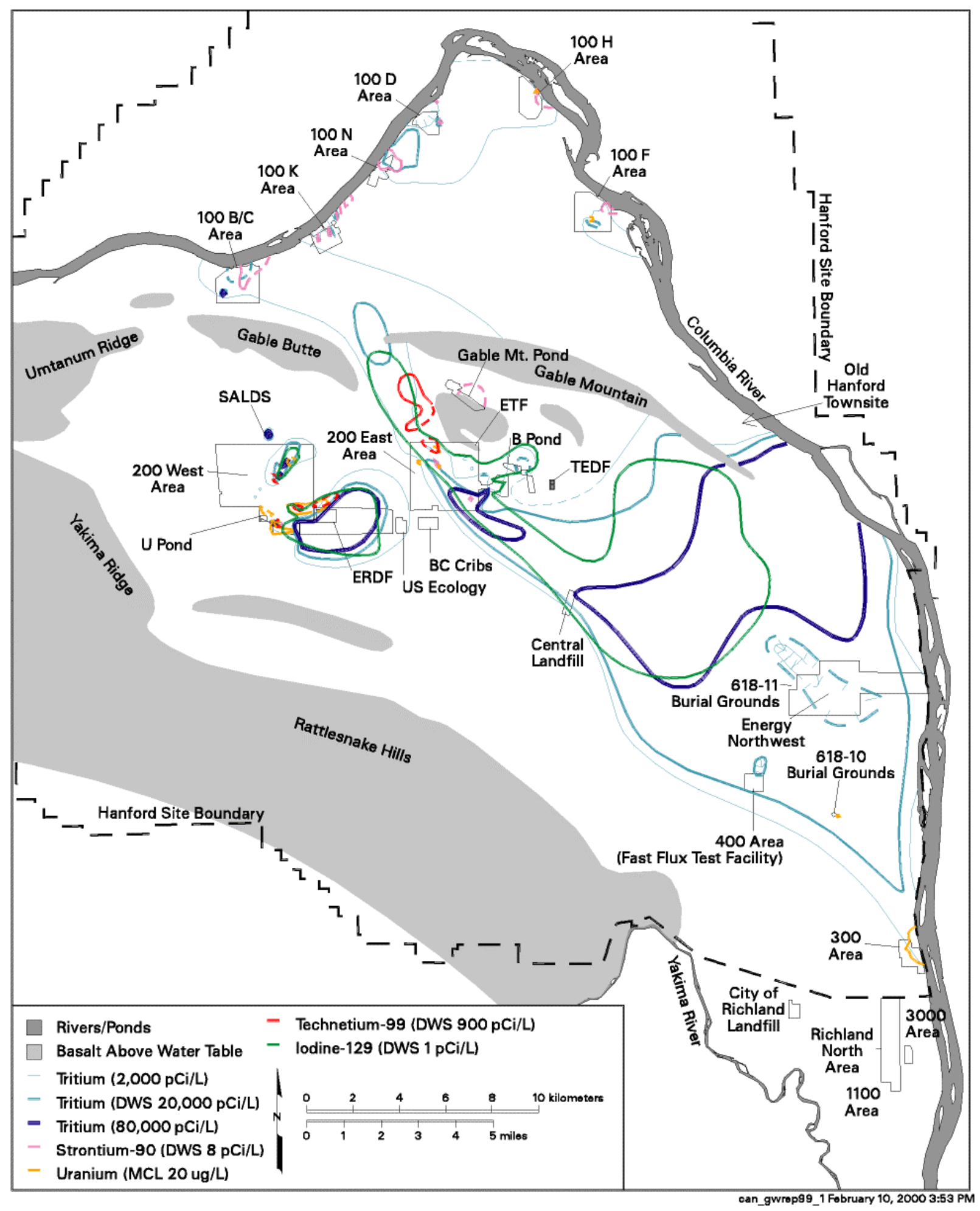

Figure 3.1. Distribution of Radionuclides in Groundwater at the Hanford Site (Hartman et al. 2000) 
Plume maps that illustrate the current distribution of strontium-90 are included in this report for each

reactor area. Because strontium-90 is adsorbed onto sediments in the aquifer, it's movement as a plume is slower than for nonadsorbed constituents, such as tritium and hexavalent chromium. Therefore, for a given waste site source, the plume for strontium will be smaller than for tritium, assuming both radionuclides are in the wastes.

Tables are provided that summarize recent analytical results for strontium-90 and gross beta where the drinking water standards are exceeded $(8 \mathrm{pCi} / \mathrm{L}$ and $50 \mathrm{pCi} / \mathrm{L}$, respectively). Gross beta is included because strontium- 90 is typically the dominant beta emitter in 100 Areas groundwater. Strontium- 90 concentrations can be inferred as approximately one-half the gross beta value where strontium-90 is the principal beta emitter present. Gross beta measurements are a less-expensive alternative to measuring specific radionuclides, and consequently, are frequently used as an indicator of contamination by radionuclides. A second key beta emitter found by gross beta measurements is technetium-99, although technetium-99 is not a common contaminant in the 100 Areas.

The groundwater data were extracted from the HEIS, evaluated for their representativeness, and summarized using the Groundwater Monitoring Project's data evaluator. A summary of strontium-90 and/or gross beta measurements at locations near the river shoreline is also presented. The aquifer sampling tube monitoring results are from Peterson et al. (1998a, Table 4.1) and riverbank seepage results are from Dirkes et al. (1999, Section 4.2.3), or from the HEIS.

For data from near-river monitoring sites, the specific conductance of the sample may be referenced to provide an indication of the relative proportions of groundwater and river water in the sample. Uncontaminated groundwater in the 100 Areas is expected to have a specific conductance in the range 350 to $400 \mu \mathrm{S} / \mathrm{cm}$, while river water is nearly constant at $130 \mu \mathrm{S} / \mathrm{cm}$. Contaminant concentrations observed in aquifer sampling tubes and riverbank seepage may reflect the dilution of groundwater by mixing with river water (see Peterson and Johnson 1992, pp. 11-28, for a discussion of this phenomenon).

\subsubsection{100-B/C Area}

Monitoring Well Results. Figure 3.2 presents the distribution of strontium-90 in the 100-B/C Area during 1999, based on data from monitoring wells. Mapped average concentrations reach a maximum of $58 \mathrm{pCi} / \mathrm{L}$ near a liquid waste disposal trench (116-C-1 trench), which recently was remediated. The plume shape reflects source sites located near the 105-B reactor, most likely disposal sites associated with fuel storage basin operations, and also the retention basins and liquid waste disposal trenches that are situated closer to the river.

Data for strontium-90 and gross beta for the last 5 years are summarized in Table 3.1. The highest average strontium- 90 concentration for that period is $66 \mathrm{pCi} / \mathrm{L}$, and the highest observed value is $170 \mathrm{pCi} / \mathrm{L}$. Both values are for the monitoring well located approximately $240 \mathrm{~m}$ inland near the $116-\mathrm{C}-1$ trench, which is relatively close to the river. 


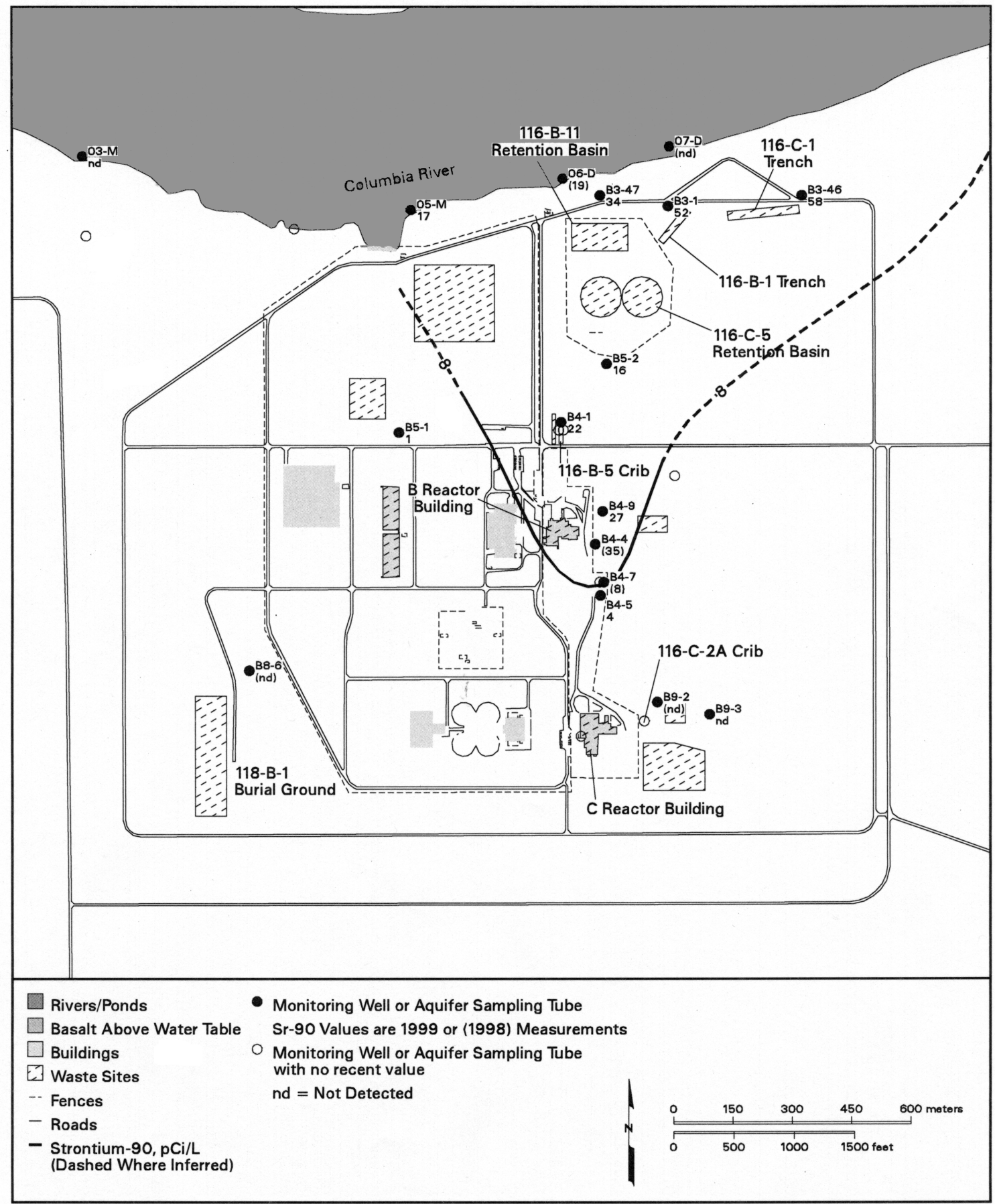

can_pete00_01 March 03, 2000 3:38 PM

Figure 3.2. Distribution of Strontium- 90 in 100-B/C Area Groundwater, 1999 
Table 3.1. Summary of Strontium-90 and Gross Beta Concentrations in 100-B/C Area Wells, 1995 to 2000

\begin{tabular}{|c|c|c|c|c|c|c|c|c|c|c|c|}
\hline Well Name & Constituent (pCi/L) & Filt? & $\begin{array}{l}\text { No. of } \\
\text { Results }\end{array}$ & $\begin{array}{c}\text { No. of } \\
\text { Detects }\end{array}$ & $\begin{array}{c}\text { No. of } \\
\text { Outliers }\end{array}$ & $\begin{array}{c}\text { Minimum } \\
\text { Value }\end{array}$ & $\begin{array}{c}\text { Maximum } \\
\text { Value }\end{array}$ & $\begin{array}{c}\text { Average } \\
\text { Value }\end{array}$ & $\begin{array}{c}\text { Standard } \\
\text { Value }\end{array}$ & $\begin{array}{c}\text { Standard } \\
\text { Reference }\end{array}$ & $\begin{array}{c}\text { No. Above } \\
\text { Standard }\end{array}$ \\
\hline \multicolumn{12}{|c|}{ Monitoring Wells: } \\
\hline 199-B3-1 & Strontium-90 & $\mathrm{N}$ & 14 & 14 & 0 & 44 & 68 & 54 & 8 & MCL & 14 \\
\hline 199-B3-2P & Strontium-90 & $\mathrm{N}$ & 3 & 3 & 0 & 4 & 63 & 25 & 8 & MCL & 1 \\
\hline 199-B3-46 & Strontium-90 & $\mathrm{N}$ & 15 & 14 & 1 & 34 & 170 & 66 & 8 & MCL & 14 \\
\hline 199-B3-47 & Strontium-90 & $\mathrm{N}$ & 14 & 14 & 0 & 17 & 39 & 25 & 8 & MCL & 14 \\
\hline 199-B4-1 & Strontium-90 & $\mathrm{N}$ & 4 & 4 & 0 & 15 & 22 & 19 & 8 & MCL & 4 \\
\hline 199-B4-4 & Strontium-90 & $\mathrm{N}$ & 3 & 3 & 0 & 21 & 35 & 27 & 8 & MCL & 3 \\
\hline 199-B4-7 & Strontium-90 & $\mathrm{N}$ & 3 & 3 & 0 & 6 & 8 & 6 & 8 & MCL & 1 \\
\hline 199-B4-9 & Strontium-90 & $\mathrm{N}$ & 5 & 5 & 0 & 22 & 36 & 29 & 8 & MCL & 5 \\
\hline 199-B5-2 & Strontium-90 & $\mathrm{N}$ & 6 & 6 & 0 & 14 & 33 & 21 & 8 & MCL & 6 \\
\hline \multicolumn{12}{|c|}{ Aquifer Sampling Tubes: } \\
\hline 05-M & Strontium-90 & $\mathrm{N}$ & 2 & 2 & 0 & 17 & 17 & 17 & 8 & MCL & 2 \\
\hline 06-D & Strontium-90 & $\mathrm{N}$ & 1 & 1 & 0 & 19 & 19 & 19 & 8 & MCL & 1 \\
\hline \multicolumn{12}{|c|}{ Monitoring Wells: } \\
\hline 199-B3-1 & Gross beta & $\mathrm{N}$ & 6 & 6 & 0 & 103 & 170 & 138 & 50 & MCL & 6 \\
\hline 199-B3-2P & Gross beta & $\mathrm{N}$ & 2 & 2 & 0 & 18 & 184 & 101 & 50 & MCL & 1 \\
\hline 199-B3-46 & Gross beta & $\mathrm{N}$ & 5 & 5 & 0 & 85 & 45 & 163 & 50 & MCL & 5 \\
\hline 199-B3-47 & Gross beta & $\mathrm{N}$ & 5 & 5 & 0 & 50 & 85 & 68 & 50 & MCL & 4 \\
\hline 199-B4-1 & Gross beta & $\mathrm{N}$ & 4 & 4 & 0 & 52 & 63 & 56 & 50 & MCL & 4 \\
\hline 199-B4-4 & Gross beta & $\mathrm{N}$ & 3 & 3 & 0 & 73 & 76 & 75 & 50 & MCL & 3 \\
\hline 199-B4-9 & Gross beta & $\mathrm{N}$ & 2 & 2 & 0 & 67 & 69 & 68 & 50 & MCL & 2 \\
\hline 199-B5-2 & Gross beta & $\mathrm{N}$ & 6 & 6 & 0 & 46 & 56 & 53 & 50 & MCL & 5 \\
\hline \multicolumn{12}{|c|}{ Aquifer Sampling Tubes: } \\
\hline 05-M & Gross beta & $\mathrm{N}$ & 2 & 2 & 0 & 56 & 58 & 57 & 50 & MCL & 2 \\
\hline 06-D & Gross beta & $\mathrm{N}$ & 1 & 1 & 0 & 52 & 52 & 52 & 50 & MCL & 1 \\
\hline \multicolumn{12}{|c|}{$\begin{array}{l}\text { Data Source: Hanford Environmental Information System; represents period January 1, 1995, through February 11, } 2000 . \\
\text { Filt = Filtered. } \\
\text { MCL = Maximum concentration level. }\end{array}$} \\
\hline
\end{tabular}


Aquifer Sampling Tube Results. Strontium-90 results for samples from aquifer sampling tubes along the 100-B/C Area shoreline during fall 1998 ranged from undetected to a maximum of $19 \mathrm{pCi} / \mathrm{L}$ (see Figure 3.2). The maximum value probably reflects groundwater that has flowed beneath the adjacent former liquid waste disposal trench (116-B-1 waste site). The value is consistent with strontium-90 observed in near-river monitoring wells, assuming some dilution of the aquifer tube samples by river water. The gross beta measured for these samples (see Table 3.1) is approximately twice the strontium-90 concentration, suggesting that strontium-90 is the principal beta emitter in the samples.

Riverbank Seepage Results. Samples were collected from two riverbank seepage sites along the 100-B/C Area shoreline during late October 1998. Strontium-90 was measured at $5.7 \mathrm{pCi} / \mathrm{L}$ at one of the seeps and undetected at the other. The two seepage sites are located on either side of the river water intake structure (i.e., prominent shoreline indentation in Figure 3.2). Specific conductance values for the seepage ( 265 and $310 \mu \mathrm{S} / \mathrm{cm}$ ) samples suggest some dilution by river water. The associated gross beta measurements also suggest that strontium-90 is the principal beta emitter in the samples.

\subsubsection{100-KE/KW Area}

Monitoring Well Results. Figure 3.3 shows a distribution map for strontium-90 that represents 1999 conditions. The maximum mapped concentration is approximately $4,050 \mathrm{pCi} / \mathrm{L}$ at a well located near the $105-\mathrm{KE}$ fuel storage basin, approximately $540 \mathrm{~m}$ inland from the river. The plume shapes reflect source sites located near the 105-KW and 105-KE reactors, and the liquid waste disposal trench (116-K-2 waste site). The plumes near the reactors are believed to be associated with former operation of the fuel storage basins. Table 3.2 summarizes analytical results for strontium- 90 and gross beta for the last 5 years. The highest average strontium- 90 concentration for that period is $6,320 \mathrm{pCi} / \mathrm{L}$, and the highest observed value is $18,600 \mathrm{pCi} / \mathrm{L}$, both occurring at the $105-\mathrm{KE}$ fuel storage basin site indicated above (well 199-K-109A).

Although the shielding water and basin sludge associated with current operation of the K-basins contain significant amounts of strontium-90, there is no intentional release of effluent to the environment. The plume located between the liquid waste disposal trench and the river has resulted from past disposal of liquid effluent that contained highly contaminated reactor coolant. The high concentrations in one well near the basin are presumed to be the result of remobilization of strontium-90 held in the vadose zone, which resulted from past-practice operations, not current operations (Johnson et al. 1998, p. 2.20).

Because strontium-90 was included in the effluent that went to the 100-K Mile Long Trench (116-K-2 waste site), it shows up in monitoring wells located between the trench and the river. Concentrations are typically less than $50 \mathrm{pCi} / \mathrm{L}$. The pump-and-treat system that removes chromium from groundwater in this area does not remove the strontium-90. It was not identified as a contaminant of concern warranting interim remedial action during the CERCLA limited field investigation (DOE-RL 1994b). The treated effluent from the system is injected back into the aquifer at a location upgradient of the trench (DOE-RL 1998b, p. 1.1). 


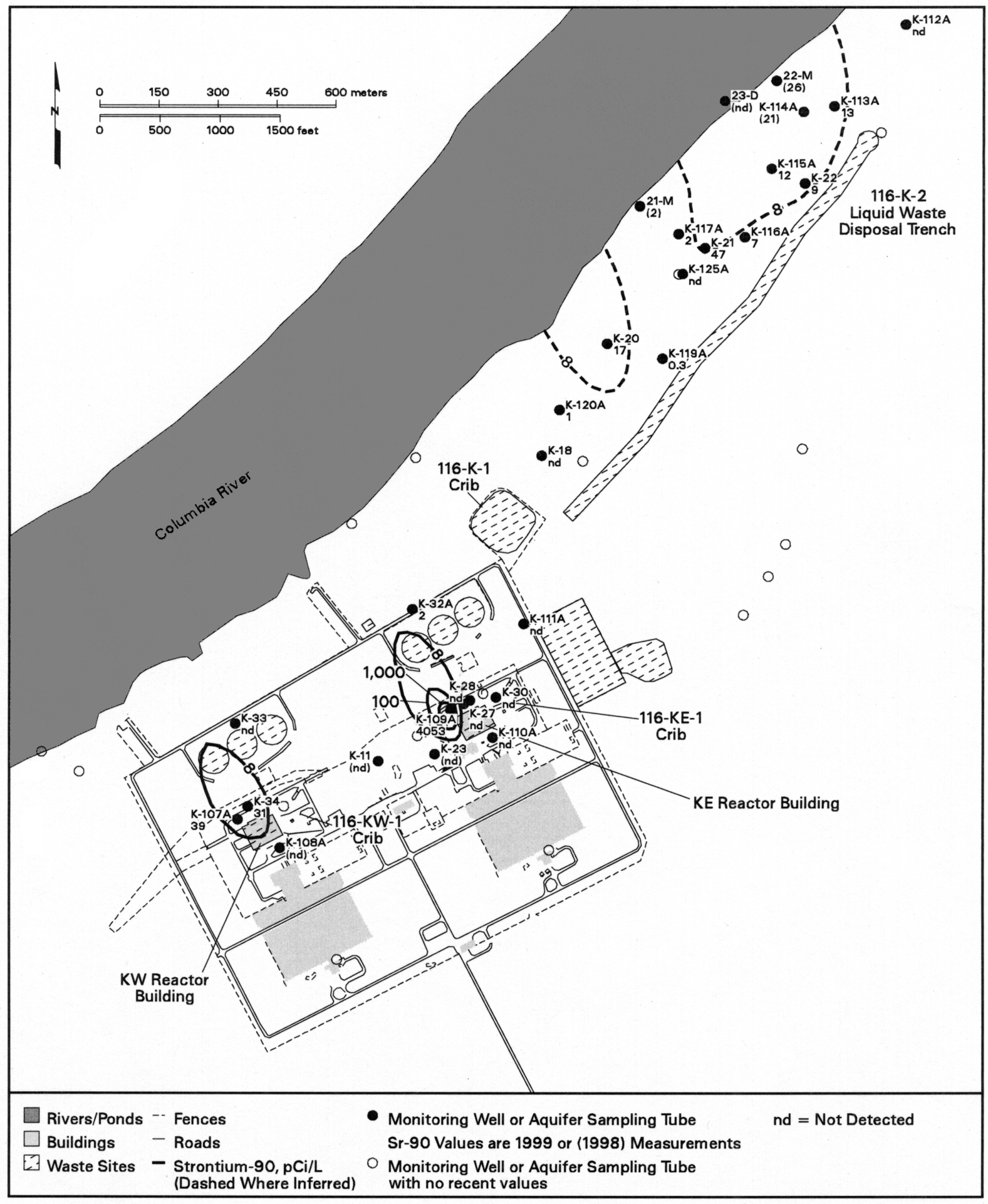

can_pete00_02 March 03, 2000 3:24 PM

Figure 3.3. Distribution of Strontium-90 in 100-K Area Groundwater, 1999 
Table 3.2. Summary of Strontium- 90 and Gross Beta Concentrations in 100-K Area Wells, 1995 to 2000

\begin{tabular}{|c|c|c|c|c|c|c|c|c|c|c|c|}
\hline Well Name & Constituent $(\mathrm{pCi} / \mathrm{L})$ & Filt? & $\begin{array}{l}\text { No. of } \\
\text { Results }\end{array}$ & $\begin{array}{l}\text { No. of } \\
\text { Detects }\end{array}$ & \begin{tabular}{c|} 
No. of \\
Outliers
\end{tabular} & $\begin{array}{c}\text { Minimum } \\
\text { Value }\end{array}$ & \begin{tabular}{|c|} 
Maximum \\
Value
\end{tabular} & $\begin{array}{l}\text { Average } \\
\text { Value }\end{array}$ & $\begin{array}{c}\text { Standard } \\
\text { Value }\end{array}$ & $\begin{array}{c}\text { Standard } \\
\text { Reference }\end{array}$ & \begin{tabular}{|c|} 
No. Above \\
Standard
\end{tabular} \\
\hline \multicolumn{12}{|c|}{ Monitoring Wells: } \\
\hline 199-K-19 & Strontium-90 & $\mathrm{N}$ & 3 & 2 & 1 & 13 & 13 & 13 & 8 & MCL & 2 \\
\hline 199-K-20 & Strontium-90 & $\mathrm{N}$ & 7 & 7 & 0 & 9 & 23 & 15 & 8 & MCL & 7 \\
\hline 199-K-21 & Strontium-90 & $\mathrm{N}$ & 5 & 5 & 0 & 27 & 48 & 35 & 8 & $\mathrm{MCL}$ & 5 \\
\hline 199-K-22 & Strontium-90 & $\mathrm{N}$ & 5 & 5 & 0 & 7 & 9 & 8 & 8 & MCL & 3 \\
\hline 199-K-23 & Strontium-90 & $\mathrm{N}$ & 7 & 3 & 0 & 0 & 11 & 4 & 8 & MCL & 1 \\
\hline 199-K-34 & Strontium-90 & $\mathrm{N}$ & 6 & 6 & 0 & 24 & 35 & 30 & 8 & MCL & 6 \\
\hline 199-K-107A & Strontium-90 & $\mathrm{N}$ & 6 & 6 & 0 & 38 & 70 & 47 & 8 & MCL & 6 \\
\hline 199-K-109A & Strontium-90 & $\mathrm{N}$ & 29 & 29 & 0 & 275 & 18,600 & 6,322 & 8 & $\mathrm{MCL}$ & 29 \\
\hline 199-K-113A & Strontium-90 & $\mathrm{N}$ & 5 & 5 & 0 & 7 & 14 & 11 & 8 & MCL & 4 \\
\hline 199-K-114A & Strontium-90 & $\mathrm{N}$ & 4 & 4 & 0 & 20 & 28 & 24 & 8 & MCL & 4 \\
\hline 199-K-115A & Strontium-90 & $\mathrm{N}$ & 5 & 5 & 0 & 12 & 16 & 13 & 8 & MCL & 5 \\
\hline \multicolumn{12}{|c|}{ Aquifer Sampling Tubes: } \\
\hline $22-\mathrm{M}$ & Strontium-90 & $\mathrm{N}$ & 2 & 2 & 0 & 18 & 26 & 22 & 8 & MCL & 2 \\
\hline \multicolumn{12}{|c|}{ Monitoring Wells: } \\
\hline $199-\mathrm{K}-21$ & Gross beta & $\mathrm{N}$ & 6 & 6 & 0 & 56 & 88 & 69 & 50 & MCL & 6 \\
\hline $199-\mathrm{K}-34$ & Gross beta & $\mathrm{N}$ & 27 & 26 & 1 & 29 & 92 & 63 & 50 & $\mathrm{MCL}$ & 22 \\
\hline 199-K-107A & Gross beta & $\mathrm{N}$ & 22 & 21 & 1 & 66 & 151 & 99 & 50 & MCL & 21 \\
\hline 199-K-109A & Gross beta & $\mathrm{N}$ & 59 & 59 & 0 & 620 & 49,000 & 10,220 & 50 & MCL & 59 \\
\hline 699-70-68 & Gross beta & $\mathrm{N}$ & 6 & 6 & 0 & 27 & 60 & 39 & 50 & MCL & 1 \\
\hline \multicolumn{12}{|c|}{ Aquifer Sampling Tubes: } \\
\hline $14-\mathrm{D}$ & Gross beta & $\mathrm{N}$ & 2 & 2 & 0 & 27 & 63 & 45 & 50 & MCL & 1 \\
\hline $22-\mathrm{M}$ & Gross beta & $\mathrm{N}$ & 2 & 2 & 0 & 42 & 55 & 48 & 50 & MCL & 1 \\
\hline
\end{tabular}


Aquifer Sampling Tube Results. Samples from aquifer sampling tubes collected in fall 1998 along the shoreline produced strontium-90 concentrations that ranged from undetected to a maximum of $26 \mathrm{pCi} / \mathrm{L}$ at a location downgradient from the 100-K crib (116-K-1 waste site) and the 100-K Mile Long Trench (116-K-2 waste site). The aquifer tube sampling results are shown on Figure 3.3 and listed in Table 3.2. Gross beta measurements on the samples are consistent with the assumption that strontium- 90 is the primary source for the beta activity.

Riverbank Seepage Results. Samples were collected in October 1998 from one riverbank seepage site located near the KW river water intake structure, i.e., downgradient of KW reactor waste sites, such as the fuel storage basin drain field. Strontium- 90 was undetected and gross beta was $5 \mathrm{pCi} / \mathrm{L}$, a very low concentration. The seepage was essentially pure groundwater, as indicated by the associated specific conductance measurement of $378 \mu \mathrm{S} / \mathrm{cm}$.

\subsubsection{100-N Area}

Monitoring Well Results. Figure 3.4 shows the strontium-90 distribution for conditions during 1999. A broadly distributed plume is present that contains peak concentrations up to approximately $22,000 \mathrm{pCi} / \mathrm{L}$, which is located in a well near the input end of the $1301-\mathrm{N}$ facility. The primary source for this contamination is reactor primary coolant bleed water and primary coolant disposed during fuel element exchanges, both of which were disposed to the 1301-N facility. Primary coolant contained significant quantities of strontium-90. During the later years of 100-N reactor operations (post-1983), these effluents were directed toward the $1325-\mathrm{N}$ crib/trench, which is located farther inland from the river.

Table 3.3 lists analytical results for the last 5 years for strontium-90 and gross beta, for $100-\mathrm{N}$ Area wells in which the drinking water standards are exceeded $(8 \mathrm{pCi} / \mathrm{L}$ and $50 \mathrm{pCi} / \mathrm{L}$, respectively). Relatively high concentrations exist in numerous wells, with the highest observed value reaching $50,000 \mathrm{pCi} / \mathrm{L}$ in a well near the $1301-\mathrm{N}$ source. The high concentrations are located in wells near the river, and also in wells located near the inland sites (i.e., 1301-N and 1325-N) where strontium-90bearing effluent was introduced to the soil column.

Strontium-90 is present in the vadose zone near the two disposal facilities, having been adsorbed onto sediments. Renewed saturation of these sediments, which occurs during periods of a higher than normal water table (e.g., 1996 and 1997), causes strontium to be remobilized. This creates considerable variability in concentrations observed at some monitoring wells. The phenomenon is discussed in detail in the annual report for FY 1997 for the 100-NR-2 groundwater operable unit (DOE-RL 1998c, pp. 2.12 through 2.15). 


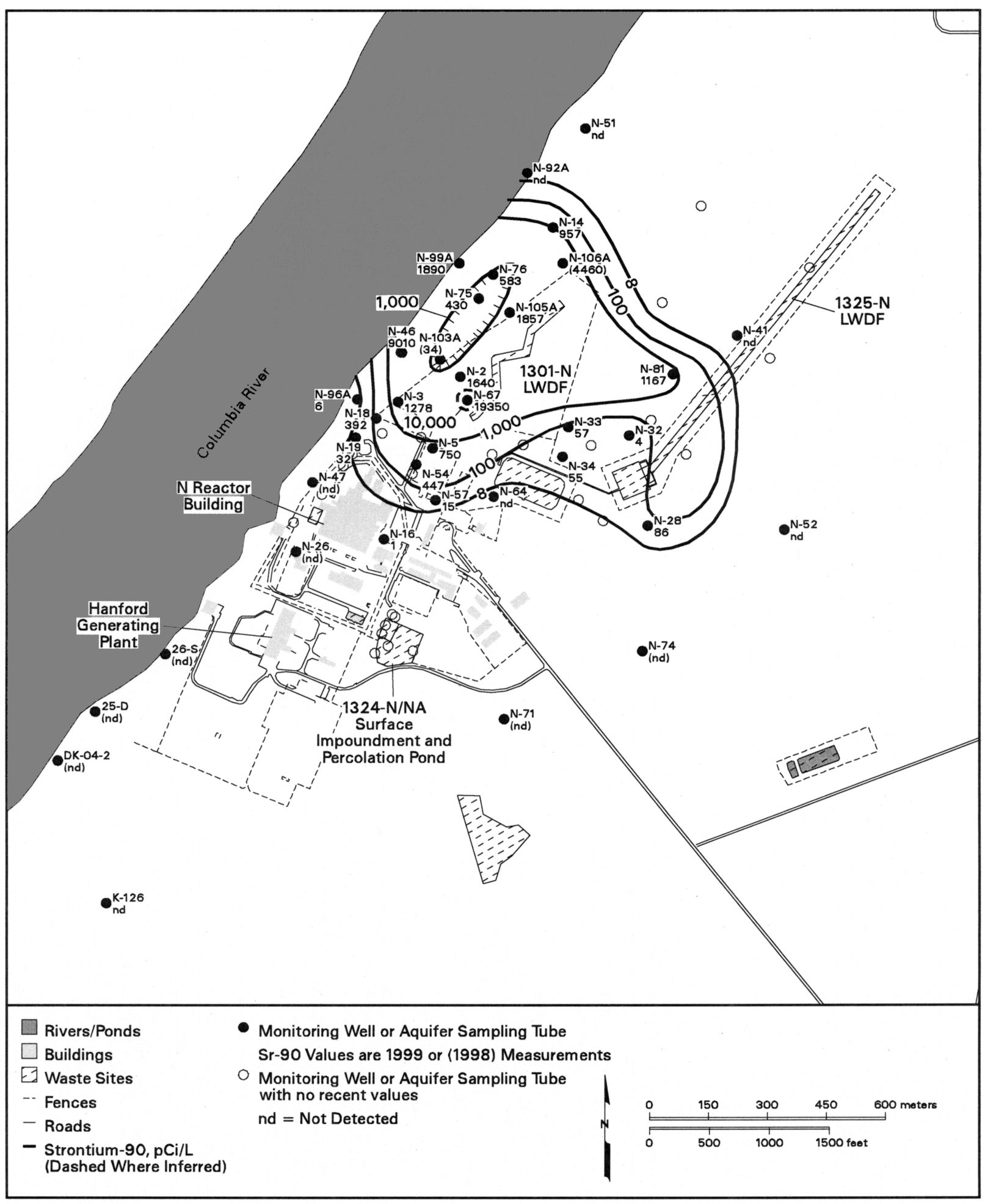

can_pete00_03 March 03, 2000 3:42 PM

Figure 3.4. Distribution of Strontium- 90 in 100-N Area Groundwater, 1999 
Table 3.3. Summary of Strontium-90 and Gross Beta Concentrations in 100-N Area Wells, 1995 to 2000

\begin{tabular}{|c|c|c|c|c|c|c|c|c|c|c|c|c|}
\hline & Well Name & Constituent (pCi/L) & Filt? & $\begin{array}{l}\text { No. of } \\
\text { Results }\end{array}$ & $\begin{array}{l}\text { No. of } \\
\text { Detects }\end{array}$ & $\begin{array}{c}\text { No. of } \\
\text { Outliers }\end{array}$ & $\begin{array}{c}\text { Minimum } \\
\text { Value }\end{array}$ & $\begin{array}{l}\text { Maximum } \\
\text { Value }\end{array}$ & $\begin{array}{l}\text { Average } \\
\text { Value }\end{array}$ & $\begin{array}{l}\text { Standard } \\
\text { Value }\end{array}$ & $\begin{array}{l}\text { Standard } \\
\text { Reference }\end{array}$ & $\begin{array}{c}\text { No. Above } \\
\text { Standard }\end{array}$ \\
\hline & $199-\mathrm{N}-2$ & Strontium-90 & $\mathrm{N}$ & 24 & 24 & 0 & 72 & 3,900 & 1,278 & 8 & MCL & 24 \\
\hline & $199-\mathrm{N}-2$ & Strontium-90 & $\mathrm{Y}$ & 1 & 1 & 0 & 138 & 138 & 138 & 8 & MCL & 1 \\
\hline & $199-\mathrm{N}-3$ & Strontium-90 & $\mathrm{N}$ & 27 & 27 & 0 & 642 & 2,500 & 1,159 & 8 & MCL & 27 \\
\hline & $199-\mathrm{N}-5$ & Strontium-90 & $\mathrm{N}$ & 6 & 6 & 0 & 750 & 1,185 & 959 & 8 & MCL & 6 \\
\hline & $199-\mathrm{N}-14$ & Strontium-90 & $\mathrm{N}$ & 28 & 28 & 0 & 502 & 1,580 & 855 & 8 & MCL & 28 \\
\hline & 199-N-14 & Strontium-90 & $\mathrm{Y}$ & 1 & 1 & 0 & 1,090 & 1,090 & 1,090 & 8 & MCL & 1 \\
\hline & $199-\mathrm{N}-18$ & Strontium-90 & $\mathrm{N}$ & 1 & 1 & 0 & 392 & 392 & 392 & 8 & MCL & 1 \\
\hline & 199-N-19 & Strontium-90 & $\mathrm{N}$ & 5 & 5 & 0 & 32 & 60 & 43 & 8 & $\mathrm{MCL}$ & 5 \\
\hline & $199-\mathrm{N}-27$ & Strontium-90 & $\mathrm{N}$ & 3 & 3 & 0 & 155 & 474 & 322 & 8 & MCL & 3 \\
\hline & $199-\mathrm{N}-28$ & Strontium-90 & $\mathrm{N}$ & 6 & 6 & 0 & 78 & 189 & 113 & 8 & MCL & 6 \\
\hline & $199-\mathrm{N}-29$ & Strontium-90 & $\mathrm{N}$ & 2 & 2 & 0 & 231 & 250 & 241 & 8 & MCL & 2 \\
\hline & 199-N-31 & Strontium-90 & $\mathrm{N}$ & 15 & 15 & 0 & 35 & 81 & 45 & 8 & $\mathrm{MCL}$ & 15 \\
\hline & \begin{tabular}{|l|}
$199-N-33$ \\
\end{tabular} & Strontium-90 & $\mathrm{N}$ & 1 & 1 & 0 & 57 & 57 & 57 & 8 & $\mathrm{MCL}$ & 1 \\
\hline & \begin{tabular}{|l|}
$199-N-34$ \\
\end{tabular} & Strontium-90 & $\mathrm{N}$ & 4 & 4 & 0 & 46 & 64 & 56 & 8 & MCL & 4 \\
\hline & 199-N-46 & Strontium-90 & $\mathrm{N}$ & 55 & 54 & 1 & 2,370 & 15,700 & 6,217 & 8 & $\mathrm{MCL}$ & 54 \\
\hline & 199-N-54 & Strontium-90 & $\mathrm{N}$ & 20 & 20 & 0 & 233 & 540 & 404 & 8 & $\mathrm{MCL}$ & 20 \\
\hline & $199-\mathrm{N}-54$ & Strontium-90 & $\mathrm{Y}$ & 1 & 1 & 0 & 399 & 399 & 399 & 8 & MCL & 1 \\
\hline & 199-N-57 & Strontium-90 & $\mathrm{N}$ & 6 & 6 & 0 & 15 & 29 & 22 & 8 & MCL & 6 \\
\hline & 199-N-67 & Strontium-90 & $\mathrm{N}$ & 31 & 31 & 0 & 5,030 & 26,000 & 14,659 & 8 & MCL & 31 \\
\hline & 199-N-67 & Strontium-90 & $\mathrm{Y}$ & 5 & 5 & 0 & 5,230 & 24,700 & 16,234 & 8 & $\mathrm{MCL}$ & 5 \\
\hline & 199-N-75 & Strontium-90 & $\mathrm{N}$ & 28 & 28 & 0 & 274 & 1,740 & 650 & 8 & $\mathrm{MCL}$ & 28 \\
\hline & 199-N-76 & Strontium-90 & $\mathrm{N}$ & 54 & 53 & 1 & 75 & 3,110 & 734 & 8 & MCL & 53 \\
\hline & \begin{tabular}{|l|}
$199-N-76$ \\
\end{tabular} & Strontium-90 & $\mathrm{Y}$ & 1 & 1 & 0 & 88 & 88 & 88 & 8 & MCL & 1 \\
\hline & 199-N-81 & Strontium-90 & $\mathrm{N}$ & 11 & 11 & 0 & 584 & 1,840 & 1,125 & 8 & MCL & 11 \\
\hline & $199-\mathrm{N}-81$ & Strontium-90 & $\mathrm{Y}$ & 1 & 1 & 0 & 1,220 & 1,220 & 1,220 & 8 & MCL & 1 \\
\hline & 199-N-96A & Strontium-90 & $\mathrm{N}$ & 21 & 19 & 2 & 2 & 9 & 6 & 8 & $\mathrm{MCL}$ & 3 \\
\hline & 199-N-96A & Strontium-90 & $\mathrm{Y}$ & 1 & 1 & 0 & 11 & 11 & 11 & 8 & MCL & 1 \\
\hline & 199-N-99A & Strontium-90 & $\mathrm{N}$ & 24 & 24 & 0 & 1,360 & 19,100 & 5,506 & 8 & MCL & 24 \\
\hline
\end{tabular}


Table 3.3. (contd)

\begin{tabular}{|c|c|c|c|c|c|c|c|c|c|c|c|}
\hline \multirow{21}{*}{$\stackrel{\omega}{N}$} & Constituent $(\mathrm{pCi} / \mathrm{L})$ & Filt? & $\begin{array}{c}\text { No. of } \\
\text { Results }\end{array}$ & $\begin{array}{c}\text { No. of } \\
\text { Detects }\end{array}$ & $\begin{array}{c}\text { No. of } \\
\text { Outliers }\end{array}$ & $\begin{array}{c}\text { Minimum } \\
\text { Value }\end{array}$ & $\begin{array}{c}\text { Maximum } \\
\text { Value }\end{array}$ & $\begin{array}{c}\text { Average } \\
\text { Value }\end{array}$ & $\begin{array}{c}\text { Standard } \\
\text { Value } \\
\end{array}$ & $\begin{array}{c}\text { Standard } \\
\text { Reference }\end{array}$ & $\begin{array}{c}\text { No. Above } \\
\text { Standard }\end{array}$ \\
\hline & Strontium-90 & $\mathrm{N}$ & 25 & 25 & 0 & 2 & 2,360 & 299 & 8 & MCL & 12 \\
\hline & Strontium-90 & $\mathrm{N}$ & 19 & 19 & 0 & 112 & 1,880 & 770 & 8 & MCL & 19 \\
\hline & Strontium-90 & $\mathrm{N}$ & 15 & 15 & 0 & 2,890 & 4,460 & 3,581 & 8 & MCL & 15 \\
\hline & Gross beta & $\mathrm{N}$ & 9 & 9 & 0 & 216 & 4,644 & 2,451 & 50 & MCL & 9 \\
\hline & Gross beta & $\mathrm{N}$ & 11 & 10 & 1 & 1,800 & 3,420 & 2,424 & 50 & MCL & 10 \\
\hline & Gross beta & $\mathrm{N}$ & 11 & 11 & 0 & 1,390 & 3,000 & 1,929 & 50 & MCL & 11 \\
\hline & Gross beta & $\mathrm{N}$ & 4 & 4 & 0 & 285 & 843 & 544 & 50 & MCL & 4 \\
\hline & Gross beta & $\mathrm{N}$ & 1 & 1 & 0 & 438 & 438 & 438 & 50 & MCL & 1 \\
\hline & Gross beta & $\mathrm{N}$ & 4 & 4 & 0 & 88 & 141 & 113 & 50 & MCL & 4 \\
\hline & Gross beta & $\mathrm{N}$ & 20 & 20 & 0 & 745 & 1,270 & 889 & 50 & MCL & 20 \\
\hline & Gross beta & $\mathrm{Y}$ & 1 & 1 & 0 & 825 & 825 & 825 & 50 & MCL & 1 \\
\hline & Gross beta & $\mathrm{N}$ & 6 & 5 & 1 & 38 & 59 & 45 & 50 & MCL & 1 \\
\hline & Gross beta & $\mathrm{N}$ & 14 & 14 & 0 & 11,110 & 50,000 & 33,002 & 50 & MCL & 14 \\
\hline & Gross beta & $\mathrm{N}$ & 14 & 14 & 0 & 499 & 2,450 & 1,150 & 50 & MCL & 14 \\
\hline & Gross beta & $\mathrm{N}$ & 12 & 11 & 1 & 165 & 1,770 & 1,105 & 50 & MCL & 11 \\
\hline & Gross beta & $\mathrm{N}$ & 7 & 7 & 0 & 1,181 & 4,470 & 2,247 & 50 & MCL & 7 \\
\hline & Gross beta & $\mathrm{N}$ & 3 & 3 & 0 & 4,080 & 5,260 & 4,747 & 50 & MCL & 3 \\
\hline & Gross beta & $\mathrm{Y}$ & 1 & 1 & 0 & 9,250 & 9,250 & 9,250 & 50 & $\mathrm{MCL}$ & 1 \\
\hline & Gross beta & $\mathrm{N}$ & 3 & 3 & 0 & 3,470 & 3,770 & 3,607 & 50 & MCL & 3 \\
\hline & \multicolumn{11}{|c|}{$\begin{array}{l}\text { Data Source: Hanford Environmental Information System; represents period January 1, 1995, through February 11, } 2000 . \\
\text { Filt = Filtered. } \\
\text { MCL = Maximum concentration level. }\end{array}$} \\
\hline
\end{tabular}


Because of the high concentrations of strontium-90 in groundwater near the river, an expedited response action was initiated in 1995 (Ecology and EPA 1994). ${ }^{(a)}$ A pump-and-treat system was designed and installed to create a hydraulic barrier between the river and the 1301-N crib, such that the rate of strontium-90 movement into the river is reduced. An evaluation of the performance of this system is conducted annually (e.g., DOE-RL 1999a) and updated semiannually. The most recent update states that the remedial action a) continues to reduce the hydraulic gradient toward the river, thus reducing the net flux to the river by greater than $90 \%$, b) continues to evaluate treatment options for strontium- 90 , and c) has provided data relevant to setting demonstrable cleanup standards for strontium-90 (ERC 1999, pp. 3.7 to 3.8). Regarding statement c), the system has treated 363.2 million liters of groundwater to date and removed $0.7 \mathrm{Ci}$ of strontium-90, thus demonstrating the difficulty in lowering groundwater concentrations using pump-and-treat technology.

Near-River Wells Results. Strontium-90 concentrations in wells located within tens of meters of the shoreline, depending on river stage, that monitor the core of the plume being addressed by the interim action currently range from $\sim 300$ to $2,500 \mathrm{pCi} / \mathrm{L}$. Much higher concentrations have been observed in the past, with the highest observed value being $19,100 \mathrm{pCi} / \mathrm{L}$ in 1996 . Strontium-90 concentrations in nearriver wells positioned at the upstream and downstream boundaries of the mapped plume (Figure 3.4) are $<10 \mathrm{pCi} / \mathrm{L}$, although there are very few results from these wells for recent years.

Aquifer Sampling Tube Results. Aquifer sampling tubes were not installed along the 100-N Area shoreline because of the coarse nature of the shoreline materials, which reduced the possibility of success when driving a temporary casing.

N Springs Seep Points Results. During the operating years for the 1301-N facility, enhanced groundwater flow toward the river and riverbank seepage developed because of mounding of the water table beneath the 1301-N facility. Carbon-steel casings ("seep points") were installed along the shoreline to facilitate sampling the contaminated groundwater (locations labeled NS-1 through NS-13). The seep points are currently measured annually by the Near-Facility Environmental Monitoring Program. Only a few of the seep points were accessible during the November 1997 sampling event because of high-river stage. Data from that event can be found in Perkins et al. (1998, pp. 6.1 to 6.3, Table 6.2). Seep point NS-3, located near the core of the target plume, had a strontium-90 value of 3,200 pCi/L. No specific conductance measurements are available to help interpret the degree of mixing between contaminated groundwater and river water at these sampling locations, so the results should be viewed as minimum values.

Riverbank Seepage Results. The most recent sample of riverbank seepage was collected in October 1998 from a riverbank seepage site ( $\mathrm{SN}-092-2)$ located approximately opposite the downstream end of the 1301-N liquid waste disposal facility (see Figure 3.4). The strontium-90 result for the 1998 sample is not

(a) Washington State Department of Ecology (Ecology) and U.S. Environmental Protection Agency (EPA). 1994. Action Memorandum: N-Springs Expedited Response Action Cleanup Plan, U.S. Department of Energy Hanford Site, Richland, Washington. Letter to R. Izatt (DOE-RL) from D. Butler (Ecology) and R. F. Smith (EPA), dated September 23, 1994, Washington State Department of Ecology and U.S. Environmental Protection Agency, Olympia, Washington. 
available; however, the associated gross beta measurement $(2.29 \mathrm{pCi} / \mathrm{L})$ suggests that strontium-90 would be undetected. The specific conductance for the sample $(290 \mu \mathrm{S} / \mathrm{cm})$ indicates some dilution by river water.

During fall 1997, a much higher strontium-90 concentration was measured in seepage at a location opposite the upstream, crib end of the 1301-N facility (see Figure 3.4) and downgradient of the highest concentrations in the strontium-90 plume. The peak value was 9,900 pCi/L (Dirkes et al. 1999, Table 4.2.3). This location could not be sampled in 1998 for logistical reasons.

\subsubsection{100-D/DR Area}

Monitoring Well Results. Strontium-90 is not widely distributed in the 100-D/DR Area. Two areas show sampling results from wells that have detectable strontium-90 (Figure 3.5). The first area is near the $105-\mathrm{D}$ reactor building, where one well has shown a relatively constant concentration of $\sim 30 \mathrm{pCi} / \mathrm{L}$. Groundwater in this area is presumably influenced by past disposal of radionuclide-bearing effluent from the 105-D Reactor fuel storage basin, which is located nearby. The second area is downgradient of the coolant water retention basins and liquid waste disposal trenches. The latter region is currently undergoing interim remedial action to remove chromium from groundwater using a pump-and-treat system. The treatment system is not designed to remove strontium-90, as that constituent was not identified as a contaminant of concern warranting interim remedial action during the CERCLA limited field investigation (DOE-RL 1994c).

Wells downgradient of the retention basins and trenches are near waste sites that were excavated in FY 1997 and FY 1998 to remove contaminated soils. Increased infiltration of surface water may have occurred because of the application of dust-control water or natural precipitation collecting in the pits. In turn, this may have remobilized strontium-90 held in the vadose zone and carried it to groundwater. Additional monitoring data are required to confirm whether this has occurred.

Table 3.4 summarizes the analytical results for the last 5 years for strontium-90 and gross beta for wells in which the drinking water standards are exceeded $(8 \mathrm{pCi} / \mathrm{L}$ and $50 \mathrm{pCi} / \mathrm{L}$, respectively). The highest average strontium- 90 value $(31 \mathrm{pCi} / \mathrm{L})$ and peak observed value $(42 \mathrm{pCi} / \mathrm{L})$ during that period occurred near the 105-D fuel storage basin percolation trench, which is located approximately $1000 \mathrm{~m}$ inland from the river. The relatively high gross beta values for well 199-D4-1 are caused by potassium-40 (not by strontium-90) that is associated with the in situ REDOX manipulation test (Hartman 1999, p. 5.38).

Aquifer Sampling Tube Results. For tubes installed during fall 1995, which monitor the plume addressed by the interim action performance for chromium, gross beta was near detection limits during fall 1997 (less than $6 \mathrm{pCi} / \mathrm{L}$, suggesting no strontium-90 contamination). Additional tubes were installed in 1997 to complete coverage of the shoreline. Contamination indicators (i.e., gross beta for strontium-90) were not detected in the initial samples collected, although results indicated appreciable dilution by river water. Strontium-90 was detected in one tube located near the former 107-D retention basin (Figure 3.5) at $4.84 \mathrm{pCi} / \mathrm{L}$ during fall 1998 sampling. 


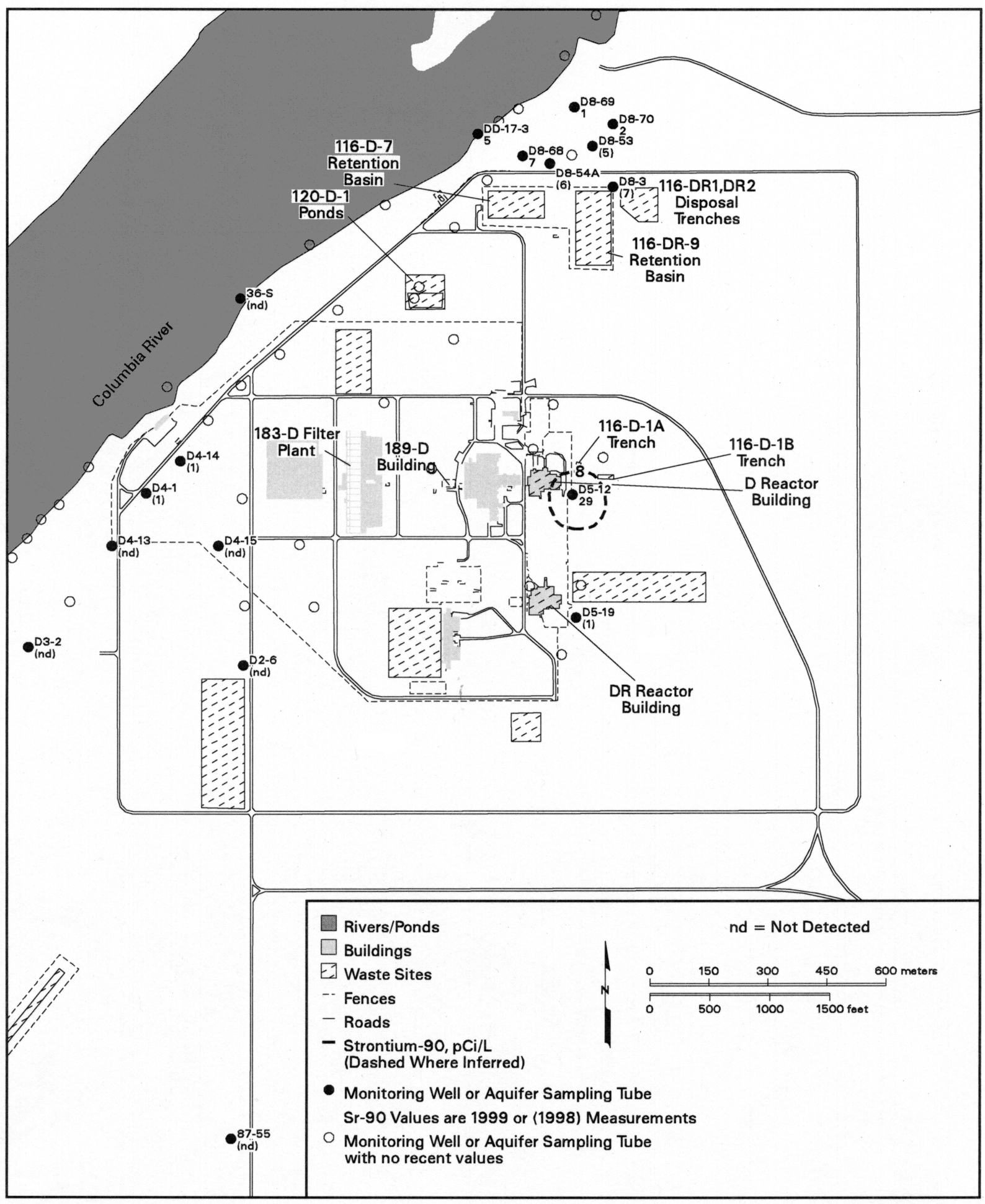

can_pete00_04 March 03, 2000 3:29 PM

Figure 3.5. Distribution of Strontium-90 in 100-D/DR Area Groundwater, 1999 
Table 3.4. Summary of Strontium- 90 and Gross Beta Concentrations in 100-D/DR Area Wells, 1995 to 2000

\begin{tabular}{|c|c|c|c|c|c|c|c|c|c|c|c|}
\hline Well Name & Constituent (pCi/L) & Filt? & $\begin{array}{l}\text { No. of } \\
\text { Results }\end{array}$ & $\begin{array}{l}\text { No. of } \\
\text { Detects }\end{array}$ & $\begin{array}{c}\text { No. of } \\
\text { Outliers }\end{array}$ & \begin{tabular}{|c|} 
Minimum \\
Value
\end{tabular} & $\begin{array}{c}\text { Maximum } \\
\text { Value }\end{array}$ & $\begin{array}{l}\text { Average } \\
\text { Value }\end{array}$ & $\begin{array}{c}\text { Standard } \\
\text { Value }\end{array}$ & \begin{tabular}{|c|} 
Standard \\
Reference \\
\end{tabular} & \begin{tabular}{|c|} 
No. Above \\
Standard
\end{tabular} \\
\hline 199-D5-12 & Strontium-90 & $\mathrm{N}$ & 18 & 18 & 0 & 25 & 42 & 31 & 8 & MCL & 18 \\
\hline 199-D5-12 & Strontium-90 & $\mathrm{Y}$ & 1 & 1 & 0 & 31 & 31 & 31 & 8 & MCL & 1 \\
\hline 199-D8-68 & Strontium-90 & $\mathrm{N}$ & 9 & 9 & 0 & 3 & 35 & 11 & 8 & $\mathrm{MCL}$ & 6 \\
\hline 199-D4-1 & Gross beta & $\mathrm{N}$ & 9 & 9 & 0 & 6 & 526 & 227 & 50 & MCL & 7 \\
\hline 199-D5-12 & Gross beta & $\mathrm{N}$ & 8 & 8 & 0 & 64 & 84 & 72 & 50 & MCL & 8 \\
\hline
\end{tabular}


Riverbank Seepage Results. Strontium-90 and gross beta concentrations were undetected or very close to detection limits for seepage samples collected during fall 1998. A single result for strontium-90 indicated a concentration of $5.28 \mathrm{pCi} / \mathrm{L}$ in seep SD-110-1, which is located near the aquifer tube described above. Specific conductance in seepage samples ranged from 160 to $245 \mu \mathrm{S} / \mathrm{cm}$, indicating an appreciable portion of river water in the samples.

\subsubsection{100-H Area}

Monitoring Well Results. Strontium-90 in groundwater at the 100-H Area is restricted mainly to the region surrounding the 107-H retention basins and adjacent liquid waste disposal trench (Figure 3.6). Because both of these facilities occasionally received reactor coolant that was highly contaminated with fuel element rupture debris, the underlying soil columns contain an inventory of radionuclides, including strontium-90. Slow downward migration of residual amounts of contamination continues to contribute to the currently observed groundwater plume.

Table 3.5 summarizes the last 5 years of analytical results for strontium- 90 and gross beta for $100-\mathrm{H}$ Area wells in which the EPA drinking water standards were exceeded $(8 \mathrm{pCi} / \mathrm{L}$ and $50 \mathrm{pCi} / \mathrm{L}$, respectively). The highest average value $(42.5 \mathrm{pCi} / \mathrm{L})$ and highest observed value $(55.3 \mathrm{pCi} / \mathrm{L})$ for strontium-90 during that period occurred in wells adjacent to the $107-\mathrm{H}$ retention basin. The summary report gross beta record labeled "47-D" is for a sample from an aquifer sampling tube located at the shoreline alongside the retention basin.

Note: The HEIS data base contains a strontium-90 result that exceeds the drinking water standard from a near-river well located within the plume whose origin is the former $183-\mathrm{H}$ solar evaporation basins (well 199-H4-12A; sample date is May 1998). The $25 \mathrm{pCi} / \mathrm{L}$ result is considered an outlier and not representative of groundwater conditions. Historical data and subsequent new data from the well and adjacent wells do not confirm the presence of strontium-90 in this area, nor are there suspected sources nearby.

Aquifer Sampling Tube Results. Strontium-90 in a water sample from aquifer tube 47, which is located opposite the former 107-H retention basin, was measured at $9.61 \mathrm{pCi} / \mathrm{L}$ during fall 1999 . Results from sampling conducted in fall 1998 were somewhat higher at $31 \mathrm{pCi} / \mathrm{L}$. These concentrations are consistent with levels observed in nearby monitoring well 199-H4-11 (see Figure 3.6). The source is suspected to be the vadose zone beneath the former retention basin and possibly a small sludge burial site located between the retention basin and the river. Both of these facilities are being remediated during 1999 and 2000, with the excavated soil being moved to the Environmental Restoration Disposal Facility in the 200 Area.

Riverbank Seepage Results. Riverbank seepage was collected during fall 1998 from several seepage sites along the 100-H shoreline. Although analyses for strontium-90 were not performed for these samples, gross beta values range from undetected to a high of $72 \mathrm{pCi} / \mathrm{L}$ at a location opposite the retention basins and close to the aquifer tube 47 described above. The specific conductance for the maximum result $(516 \mu \mathrm{S} / \mathrm{cm})$ indicates that the sample is primarily groundwater, with little dilution by river water. 


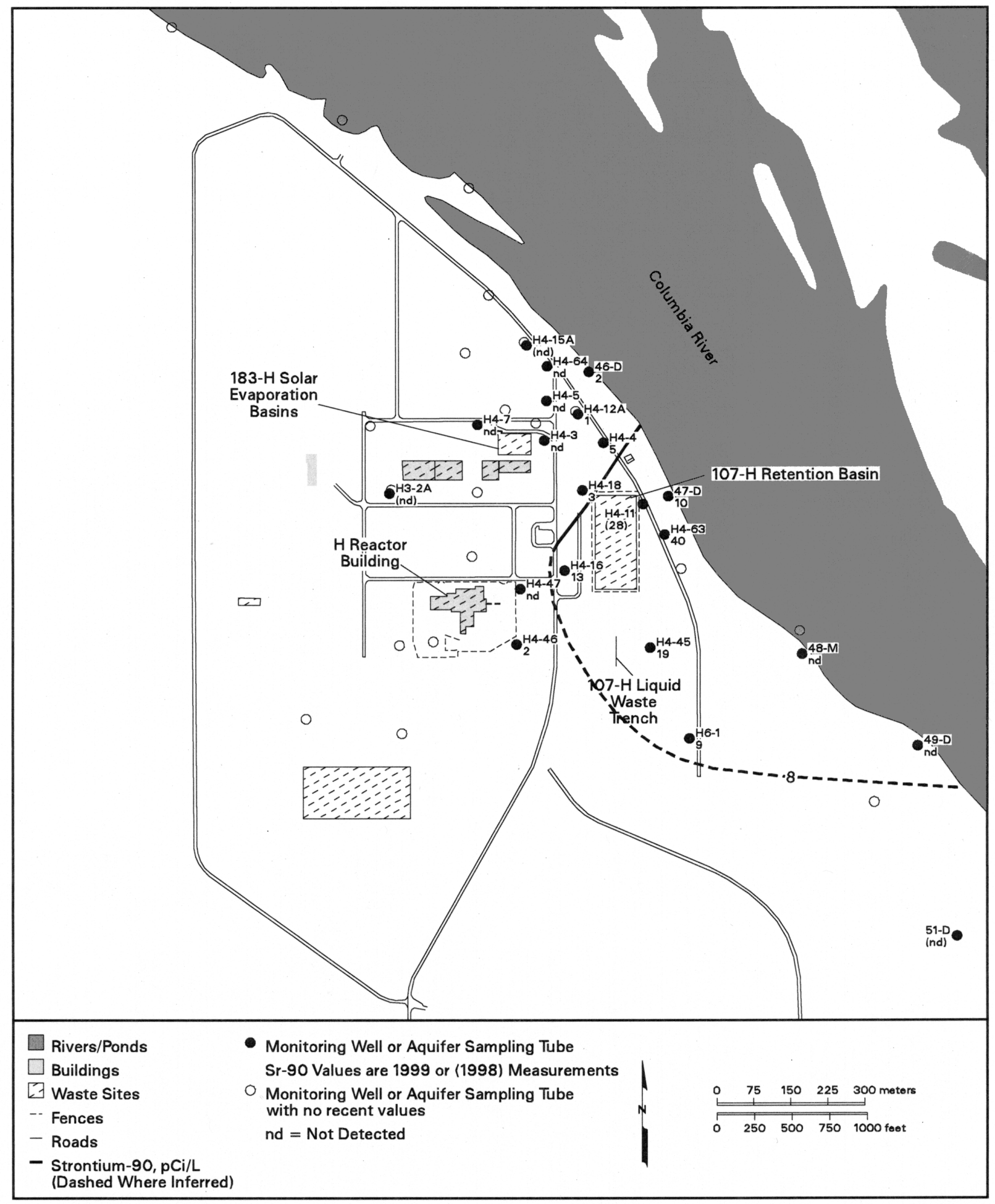

can_pete00_05 March 03, 2000 4:49 PM

Figure 3.6. Distribution of Strontium-90 in 100-H Area Groundwater, 1999 
Table 3.5. Summary of Strontium-90 and Gross Beta Concentrations in 100-H Area Wells, 1995 to 2000

\begin{tabular}{|c|c|c|c|c|c|c|c|c|c|c|c|}
\hline Well Name & Constituent $(\mathrm{pCi} / \mathrm{L})$ & Filt? & $\begin{array}{c}\text { No. of } \\
\text { Results }\end{array}$ & $\begin{array}{l}\text { No. of } \\
\text { Detects }\end{array}$ & $\begin{array}{c}\text { No. of } \\
\text { Outliers }\end{array}$ & $\begin{array}{c}\text { Minimum } \\
\text { Value }\end{array}$ & $\begin{array}{c}\text { Maximum } \\
\text { Value }\end{array}$ & $\begin{array}{c}\text { Average } \\
\text { Value }\end{array}$ & $\begin{array}{l}\text { Standard } \\
\text { Value }\end{array}$ & $\begin{array}{c}\text { Standard } \\
\text { Reference }\end{array}$ & $\begin{array}{c}\text { No. Above } \\
\text { Standard }\end{array}$ \\
\hline \multicolumn{12}{|c|}{ Monitoring Wells: } \\
\hline 199-H4-4 & Strontium-90 & $\mathrm{N}$ & 7 & 6 & 0 & 1 & 11 & 6 & 8 & MCL & 1 \\
\hline 199-H4-11 & Strontium-90 & $\mathrm{N}$ & 10 & 10 & 0 & 14 & 30 & 21 & 8 & MCL & 10 \\
\hline 199-H4-13 & Strontium-90 & $\mathrm{N}$ & 4 & 4 & 0 & 17 & 32 & 24 & 8 & MCL & 4 \\
\hline 199-H4-16 & Strontium-90 & $\mathrm{N}$ & 5 & 5 & 0 & 3 & 13 & 8 & 8 & MCL & 2 \\
\hline 199-H4-45 & Strontium-90 & $\mathrm{N}$ & 4 & 4 & 0 & 9 & 19 & 15 & 8 & MCL & 4 \\
\hline 199-H4-63 & Strontium-90 & $\mathrm{N}$ & 11 & 11 & 0 & 24 & 55 & 43 & 8 & $\mathrm{MCL}$ & 11 \\
\hline 199-H6-1 & Strontium-90 & $\mathrm{N}$ & 4 & 3 & 0 & 5 & 9 & 8 & 8 & MCL & 2 \\
\hline \multicolumn{12}{|c|}{ Aquifer Sampling Tubes: } \\
\hline $47-\mathrm{D}$ & Strontium-90 & $\mathrm{N}$ & 1 & 1 & 0 & 10 & 10 & 10 & 8 & MCL & 1 \\
\hline 47-M & Strontium-90 & $\mathrm{N}$ & 1 & 1 & 0 & 31 & 31 & 31 & 8 & $\mathrm{MCL}$ & 1 \\
\hline \multicolumn{12}{|c|}{ Monitoring Wells: } \\
\hline 199-H4-3* & Gross beta & $\mathrm{N}$ & 9 & 9 & 0 & 64 & 593 & 388 & 50 & MCL & 9 \\
\hline 199-H4-4* & Gross beta & $\mathrm{N}$ & 19 & 19 & 0 & 6 & 722 & 182 & 50 & $\mathrm{MCL}$ & 14 \\
\hline 199-H4-5* & Gross beta & $\mathrm{N}$ & 5 & 5 & 0 & 2 & 323 & 82 & 50 & $\mathrm{MCL}$ & 2 \\
\hline 199-H4-9* & Gross beta & $\mathrm{N}$ & 6 & 6 & 0 & 16 & 881 & 212 & 50 & $\mathrm{MCL}$ & 2 \\
\hline 199-H4-11* & Gross beta & $\mathrm{N}$ & 4 & 4 & 0 & 41 & 71 & 56 & 50 & MCL & 2 \\
\hline 199-H4-13 & Gross beta & $\mathrm{N}$ & 9 & 9 & 0 & 33 & 92 & 74 & 50 & MCL & 6 \\
\hline 199-H4-18* & Gross beta & $\mathrm{N}$ & 6 & 6 & 0 & 14 & 89 & 48 & 50 & $\mathrm{MCL}$ & 3 \\
\hline 199-H4-63 & Gross beta & $\mathrm{N}$ & 3 & 3 & 0 & 71 & 120 & 97 & 50 & $\mathrm{MCL}$ & 3 \\
\hline \multicolumn{12}{|c|}{ Aquifer Sampling Tubes: } \\
\hline $47-\mathrm{D}$ & Gross beta & $\mathrm{N}$ & 1 & 1 & 0 & 54 & 54 & 54 & 50 & MCL & 1 \\
\hline $47-\mathrm{M}$ & Gross beta & $\mathrm{N}$ & 1 & 1 & 0 & 97 & 97 & 97 & 50 & MCL & 1 \\
\hline \multicolumn{12}{|c|}{$\begin{array}{l}\text { Data Source: Hanford Environmental Information System; represents period January 1, } 1995 \text { through February 12, 2000. Wells marked with an asterisk } \\
\text { (*) monitor groundwater containing technetium-99, which also contributes to gross beta levels. } \\
\text { Filt = Filtered. } \\
\text { MCL = Maximum concentration level. }\end{array}$} \\
\hline
\end{tabular}


Riverbed Pore Water Results. Divers collected samples of riverbed sediment pore water during spring 1995 (Hope and Peterson 1996). The purpose of the study was to investigate hexavalent chromium levels in habitat suitable for salmon spawning. At the time, analyses for radionuclides were not performed. Archived samples from several pore water sampling sites were subsequently analyzed for strontium-90, and the results are shown in Table 3.6. All of the sampling sites listed in Table 3.6 are located in the vicinity of the northeast corner of the 107-H retention basin (see Figure 3.6). Strontium-90 was not detected in the archival water samples.

The specific conductance of the pore water samples suggests that they are primarily river water, with a minor component of groundwater. Depending on the nature of the riverbed sediments, some amount of river water flows through the sediments and mixes with groundwater that upwells from the aquifer into the channel (Geist and Dauble 1998). Therefore, the undiluted groundwater that is approaching the riverbed may contain higher concentrations of contaminants than indicated in Table 3.6.

\subsubsection{100-F Area}

Monitoring Well Results. As in the other reactor areas, the strontium-90 contamination currently present in 100-F Area groundwater is focused around the retention basins and their associated liquid waste disposal trenches (Figure 3.7). Groundwater movement is toward the southeast from these facilities at least part of the time, possibly along the pathway of a former river channel. As a result, contamination indicators have shown up in bank seepage and sediment samples from F-Slough (located just off the map shown in Figure 3.7). Analytical results for the last 5 years are summarized in Table 3.7, for 100-F Area

Table 3.6. Chromium and Strontium-90 Results for Riverbed Pore Water, 100-H Area

\begin{tabular}{|c|c|c|c|c|c|}
\hline $\begin{array}{c}\text { Riverbed } \\
\text { Sampling Site } \\
\end{array}$ & $\begin{array}{c}\text { Distance } \\
\text { Offshore } \\
(\mathrm{m}) \\
\end{array}$ & $\begin{array}{c}\text { Sample Specific } \\
\text { Conductance } \\
(\mu \mathrm{S} / \mathrm{cm}) \\
\end{array}$ & $\begin{array}{c}\text { Hexavalent } \\
\text { Chromium } \\
(\mu \mathrm{g} / \mathrm{L})\end{array}$ & $\begin{array}{c}\text { Strontium-90 } \\
(\mathrm{pCi} / \mathrm{L})\end{array}$ & $\begin{array}{c}\text { Strontium-90 } \\
\text { Detection Limit } \\
(\mathrm{pCi} / \mathrm{L}) \\
\end{array}$ \\
\hline TH-1A & 21 & 207 & 100 & -0.436 & 3.2 \\
\hline TH-1A duplicate & 21 & 198 & 130 & 0.931 & 7.72 \\
\hline TH-1B & 30 & 155 & 52 & -1.02 & 3.14 \\
\hline TH-1B duplicate & 30 & 183 & 103 & -4.2 & 9.01 \\
\hline TH-2A & 30 & 149 & $<1$ & -0.751 & 4.62 \\
\hline TH-2B & 43 & 137 & $<1$ & -0.034 & 3.83 \\
\hline TH-3A & 12 & 175 & 1.2 & 0.523 & 4.77 \\
\hline TH-3B & 24 & 147 & 9 & 3.27 & 3.83 \\
\hline TH-13A & 7 & 177 & 2.6 & 0.23 & 3.85 \\
\hline TH-14A & 7 & 190 & 73 & -0.551 & 3.1 \\
\hline \multicolumn{6}{|c|}{$\begin{array}{l}\text { Notes: The } 100-\mathrm{H} \text { Area pore water study was conducted in March and April } 1995 \text { (Hope and Peterson } \\
\text { 1996). The specific conductance of river water measured at the pore water sampling sites ranged between } \\
149 \text { and } 155 \mu \mathrm{S} / \mathrm{cm} \text {, thus indicating that the samples were primarily river water entrained in the riverbed } \\
\text { gravels. Strontium-90 analyses were performed on archived pore water samples during August } 1999 \text {. All } \\
\text { results for strontium-90 indicate nondetection. }\end{array}$} \\
\hline
\end{tabular}




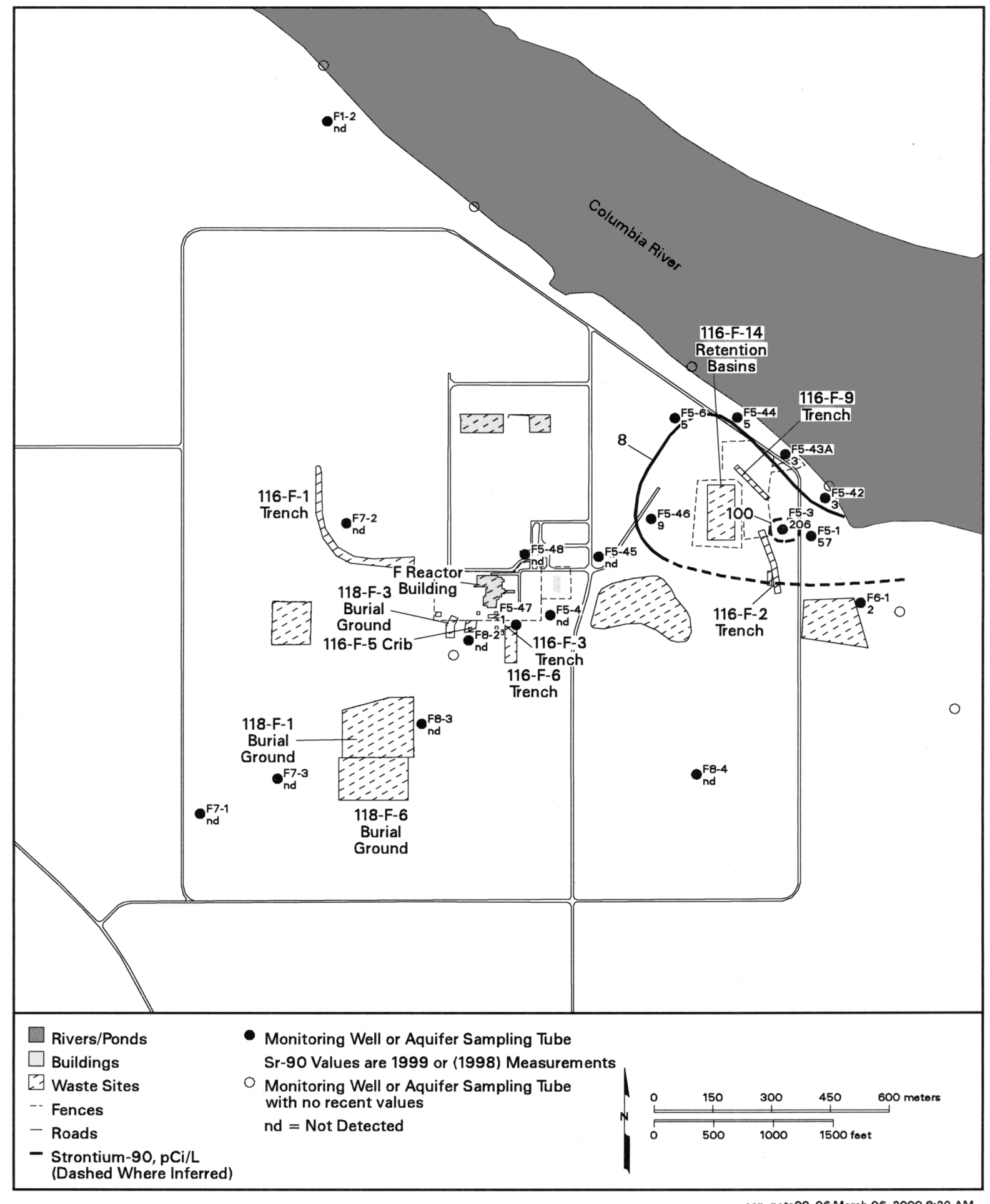

can_pete00_06 March 06, 2000 8:29 AM

Figure 3.7. Distribution of Strontium-90 in 100-F Area Groundwater, 1999 
Table 3.7. Summary of Strontium-90 and Gross Beta Concentrations in 100-F Area Wells, 1995 to 2000

\begin{tabular}{|c|c|c|c|c|c|c|c|c|c|c|c|}
\hline Well Name & Constituent (pCi/L) & Filt? & $\begin{array}{l}\text { No. of } \\
\text { Results }\end{array}$ & $\begin{array}{l}\text { No. of } \\
\text { Detects }\end{array}$ & $\begin{array}{c}\text { No. of } \\
\text { Outliers }\end{array}$ & $\begin{array}{c}\text { Minimum } \\
\text { Value }\end{array}$ & $\begin{array}{c}\text { Maximum } \\
\text { Value }\end{array}$ & $\begin{array}{c}\text { Average } \\
\text { Value }\end{array}$ & $\begin{array}{c}\text { Standard } \\
\text { Value }\end{array}$ & $\begin{array}{c}\text { Standard } \\
\text { Reference }\end{array}$ & $\begin{array}{l}\text { No. Above } \\
\text { Standard }\end{array}$ \\
\hline 199-F5-1 & Strontium-90 & $\mathrm{N}$ & 16 & 16 & 0 & 10 & 130 & 55 & 8 & MCL & 16 \\
\hline 199-F5-3 & Strontium-90 & $\mathrm{N}$ & 10 & 10 & 0 & 129 & 429 & 252 & 8 & MCL & 10 \\
\hline 199-F5-3 & Strontium-90 & $\mathrm{Y}$ & 1 & 1 & 0 & 136 & 136 & 136 & 8 & MCL & 1 \\
\hline 199-F5-44 & Strontium-90 & $\mathrm{N}$ & 4 & 4 & 0 & 4 & 9 & 6 & 8 & MCL & 2 \\
\hline 199-F5-46 & Strontium-90 & $\mathrm{N}$ & 9 & 9 & 0 & 8 & 12 & 10 & 8 & MCL & 9 \\
\hline 199-F5-47 & Strontium-90 & $\mathrm{N}$ & 7 & 6 & 0 & 1 & 8 & 4 & 8 & MCL & 1 \\
\hline 199-F5-48 & Strontium-90 & $\mathrm{N}$ & 5 & 2 & 0 & 1 & 9 & 5 & 8 & MCL & 1 \\
\hline 199-F5-6 & Strontium-90 & $\mathrm{N}$ & 7 & 7 & 0 & 4 & 8 & 6 & 8 & MCL & 1 \\
\hline 199-F6-1 & Strontium-90 & $\mathrm{N}$ & 4 & 4 & 0 & 1 & 18 & 6 & 8 & MCL & 1 \\
\hline 199-F5-1 & Gross beta & $\mathrm{N}$ & 11 & 10 & 1 & 48 & 240 & 115 & 50 & MCL & 9 \\
\hline 199-F5-3 & Gross beta & $\mathrm{N}$ & 1 & 1 & 0 & 918 & 918 & 918 & 50 & MCL & 1 \\
\hline 199-F8-1 & Gross beta & $\mathrm{N}$ & 2 & 2 & 0 & 63 & 98 & 81 & 50 & MCL & 2 \\
\hline
\end{tabular}


wells in which the drinking water standards were exceeded. The highest average strontium-90 concentration $(251.6 \mathrm{pCi} / \mathrm{L})$ and highest observed result $(429 \mathrm{pCi} / \mathrm{L})$ for that period occurred in a well adjacent to a liquid waste disposal trench.

Aquifer Sampling Tube Results. Water samples from tubes installed along the 100-F Area shoreline during the fall 1997 project were analyzed for chemical and radiological contamination indicators. The highest concentration observed for gross beta was $7.7 \mathrm{pCi} / \mathrm{L}$, which was from a tube located in the F-Slough area. Strontium-90 was not part of the analytical suite for the initial water samples, but can be inferred to be below the $8 \mathrm{pCi} / \mathrm{L}$ drinking water standard, based on the gross beta value. Subsequent sampling during 1998 and 1999 did not reveal gross beta values above $7.7 \mathrm{pCi} / \mathrm{L}$.

Riverbank Seepage Results. Samples were collected from two riverbank seepage sites along the 100-F Area shoreline during late October 1998. Strontium-90 was not detected in either sample. The gross beta measurements were 5.87 and $5.66 \mathrm{pCi} / \mathrm{L}$.

\subsubsection{300 Area}

Monitoring Well Results. Strontium-90 is not a principal contaminant of concern in the 300 Area, although it has been detected in a well near the 324 Building; a plume map has not been included for this contaminant. Although there may have been a release of strontium-90 in the vicinity of the 324 building, the reported $8.7 \mathrm{pCi} / \mathrm{L}$ in December 1995 was the only result greater than the interim drinking water standards since 1986. Table 3.8 summarizes the last 5 years of analytical results for strontium- 90 and gross beta for 300 Area wells in which the drinking water standards are exceeded $(8 \mathrm{pCi} / \mathrm{L}$ and $50 \mathrm{pCi} / \mathrm{L}$, respectively). Although the gross beta standard is exceeded in numerous wells, possibly from a uranium daughter radionuclide (Hartman 1999, p. 5.114), strontium-90 is detected at only one location, and at an average concentration of $4.2 \mathrm{pCi} / \mathrm{L}$, with a maximum observed value of $8.7 \mathrm{pCi} / \mathrm{L}$.

Aquifer Sampling Tubes. Strontium-90 analyses have not been conducted on samples from aquifer sampling tubes that were installed along the 300 Area river shoreline in 1999.

Riverbank Seepage Results. Five riverbank seepage sites were sampled as part of the 300-FF-5 Operable Unit remedial investigation in the early 1990s (DOE-RL 1994a, pp. 2.3 to 2.4, and A.2). Strontium-90 was not detected in any of these samples. More recently, riverbank seepage at one 300 Area site was sampled and analyzed for gross beta activity. The concentration in 1998 was $21 \mathrm{pCi} / \mathrm{L}$ and is not believed to be related to strontium-90 in groundwater.

\subsubsection{Columbia River}

The concentration of strontium-90 in Columbia River water upstream of the Hanford Site at Priest Rapids Dam in 1998 averaged $0.080 \mathrm{pCi} / \mathrm{L}$. This compares with an average value for the preceding 5 years of $0.086 \mathrm{pCi} / \mathrm{L}$. The maximum value observed during the 5 -year period was $0.14 \mathrm{pCi} / \mathrm{L}$. The source for this strontium-90 is global atmospheric fallout from aboveground nuclear weapons testing. This strontium-90 accumulates in the tributaries and mainstem of the Columbia River drainage system. 
Table 3.8. Summary of Strontium- 90 and Gross Beta Concentrations in 300 Area Wells, 1995 to 2000

\begin{tabular}{|c|c|c|c|c|c|c|c|c|c|c|c|}
\hline Well Name & Constituent (pCi/L) & Filt? & $\begin{array}{l}\text { No. of } \\
\text { Results }\end{array}$ & $\begin{array}{l}\text { No. of } \\
\text { Detects }\end{array}$ & $\begin{array}{l}\text { No. of } \\
\text { Outliers }\end{array}$ & $\begin{array}{l}\text { Minimum } \\
\text { Value }\end{array}$ & $\begin{array}{c}\text { Maximum } \\
\text { Value }\end{array}$ & $\begin{array}{l}\text { Average } \\
\text { Value }\end{array}$ & $\begin{array}{l}\text { Standard } \\
\text { Value }\end{array}$ & $\begin{array}{l}\text { Standard } \\
\text { Reference }\end{array}$ & $\begin{array}{l}\text { No. Above } \\
\text { Standard }\end{array}$ \\
\hline $399-3-11$ & Strontium-90 & $\mathrm{N}$ & 6 & 6 & 0 & 3 & 9 & 4 & 8 & MCL & 1 \\
\hline 399-1-3 & Gross beta & $\mathrm{N}$ & 1 & 1 & 0 & 57 & 57 & 57 & 50 & MCL & 1 \\
\hline \multicolumn{12}{|c|}{$\begin{array}{l}\text { Data Source: Hanford Environmental Information System; represents period January 1, 1995, through February 11, } 2000 . \\
\text { Filt = Filtered. } \\
\text { MCL = Maximum concentration level. }\end{array}$} \\
\hline
\end{tabular}


At the city of Richland water intake pump house downstream of the Hanford Site, the 1998 average concentration was $0.077 \mathrm{pCi} / \mathrm{L}$. The average for the previous 5 years was $0.088 \mathrm{pCi} / \mathrm{L}$. The maximum concentration observed at the pump house during the 5 -year period was $0.30 \mathrm{pCi} / \mathrm{L}$. There is no statistically significant difference between the upstream and downstream values for strontium-90 in Columbia River water (Dirkes et al. 1999, p. 4.24).

All radiological concentrations in Columbia River water samples collected in 1998 were below the DOE's derived concentration guideline and the Washington State ambient surface water criteria, i.e., 8 pCi/L for strontium-90, which is based on the EPA drinking water standard (Dirkes et al. 1999, p. 4.22 and Tables A.1 and A.2).

\subsubsection{Potential Future Conditions}

In the 100 Areas, the shielding water and sludge within the two 100-K Area fuel storage basins represent potential sources for strontium-90. Release to the environment would only occur in the event of leaks during storage or an accident during removal of spent fuel, water, and sludge from the basins.

The vadose zone beneath several 100 Areas facilities contains significant inventories of radionuclides, including strontium-90 (Dorian and Richards 1978). These contaminated zones are primarily beneath the liquid waste disposal trenches at each reactor area. Additional sites are located beneath soil column disposal facilities used for sludges and shielding water from the fuel storage basins. These locations are potential sites for future contributions of strontium- 90 to groundwater if there is increased saturation of the vadose zone. Increased infiltration from the surface, because of natural precipitation and/or human activities such as irrigation, would increase the degree of saturation. An elevated water table during unusually wet seasons has been shown to remobilize strontium-90 in the 100-N Area (DOE-RL 1998c, pp. 2.12 to 2.15). Preliminary studies of effects on the Hanford Site of the proposed Ben Franklin Dam included consideration of remobilizing long-lived radionuclides on the soil column by the consequently elevated water table (Harty 1979; Haney 1967).

In the 200 Areas, where significant amounts of strontium-90 are contained in stored wastes, release of strontium-90 to groundwater in amounts greater than those currently observed could be possible in the future. However, considering the retardation characteristics of the aquifer sediments and the distance to the river, the probability of significant new plumes reaching the river is presumed to be low. The Hanford sitewide groundwater flow model has been used to predict the future distribution of several contaminants from 200 Areas sources. For the year 2049, the prediction indicates that strontium-90 will remain in the general vicinity of the 200 Area plateau; i.e., it will not reach the Columbia River (Hartman 1999, Figure 6.9). The transport and fate of radionuclides potentially released to groundwater in the 200 Areas is being addressed under the System Assessment Capability task of the Groundwater/Vadose Zone Integration Project (DOE-RL 1999b, p. 3.3). 


\subsection{Groundwater Remediation Activities}

Near the Columbia River, DOE and its contractors are conducting interim remedial actions to address strontium-90 contamination at the 100-N Area and chromium contamination in the 100-K, 100-D/DR, and 100-H Areas. In the $200 \mathrm{West}$ Area, two interim remedial actions are being conducted. The first removes technetium-99 and uranium, along with co-contaminants carbon tetrachloride and nitrate (200-UP-1), and the second addresses carbon tetrachloride and other co-contaminant volatile organic compounds (200-ZP-1).

\subsubsection{0-N Pump-and-Treat System}

In the 100-N Area, a pump-and-treat system is currently operating that reduces the rate of strontium-90 movement toward the Columbia River (Hartman 1999, pp. 5.29-5.30), and in the process, also removes strontium-90 from the extracted groundwater. The goals of the pump-and-treat system are to 1) reduce strontium- 90 contaminant flux from the groundwater to the river, 2) evaluate commercially available treatment options for strontium-90, and 3) provide data necessary to set demonstrable strontium90 groundwater-cleanup standards (Ecology and EPA 1994). ${ }^{\text {(a) }}$

The system has been operating at the 100-NR-2 Operable Unit since 1995 as an expedited response action under CERCLA. It consists of an extraction well network, treatment facility, and injection well network. The system operates at a minimum rate of $227 \mathrm{~L} / \mathrm{min}$. The extraction well network includes four wells located between the Columbia River and the 1301-N crib. These wells are used to create a hydraulic barrier between the river and crib, thus reducing the rate at which strontium- 90 contamination enters the river.

At any given time, three of the four wells are online, with contaminated groundwater being extracted and pumped to the treatment facility. The fourth well is kept in standby mode. The pumping rate for each well is established to maximize the overall hydraulic influence of the extraction well network. The treatment facility includes an ion-adsorption system, which uses clinoptilolite (a natural zeolite mineral) to remove strontium-90 from the extracted groundwater. Treated water is injected upgradient of the 1301-N crib into two wells, each receiving half of the treated water. The performance characteristics of the expedited response action for FY 1998 are described in the annual report for the 100-NR-2 Operable Unit (DOE-RL 1999a), from which the following information is taken.

During FY 1998, the interim-action pump-and-treat system operated at a nominal rate of $233 \mathrm{~L} / \mathrm{min}$. A total of $110,100,000 \mathrm{~L}$ of water was processed. System availability for the period was $89 \%$ (hours operating/available hours, not including outage for resin replacement, preventive maintenance, or

(a) Washington State Department of Ecology (Ecology) and U.S. Environmental Protection Agency (EPA). 1994. Action Memorandum: N-Springs Expedited Response Action Cleanup Plan, U.S. Department of Energy Hanford Site, Richland, Washington. Letter to R. Izatt (DOE-RL) from D. Butler (Ecology) and R. F. Smith (EPA), dated September 23, 1994, Washington State Department of Ecology and U.S. Environmental Protection Agency, Olympia, Washington. 
scheduled maintenance outages). The system was shut down every 5 to 6 weeks for resin replacement, which usually lasted 2 to 3 days. Nine resin replacements occurred during FY 1998.

Three extraction wells operated during FY 1998, while the fourth available well was kept in standby mode. The three operating wells had average flow rates as follows: $199-\mathrm{N}-75$ (59.4 L/min), 199-N-103A (60.2 L/min), and 199-N-106A (115 L/min). These rates are similar to those experienced during previous years.

Extraction wells were sampled once during the year, and the samples were analyzed for strontium-90, with the following results: 199-N-75 (407 pCi/L), 199-N-103A (34 pCi/L), and 199-N-106A (4,460 $\mathrm{pCi} / \mathrm{L})$. The combined average influent concentration to the treatment system was $2,348 \mathrm{pCi} / \mathrm{L}$, and the average effluent concentration was $473 \mathrm{pCi} / \mathrm{L}$. The treated effluent was injected back into the aquifer via wells $199-\mathrm{N}-104 \mathrm{~A}$ and $199-\mathrm{N}-29$, which are located near the southwestern end of the 1325-N facility.

The following summarizes FY 1998 progress in meeting stated objectives for the remedial action:

- The pump-and-treat operation continued to reduce the hydraulic gradient toward the river, thus reducing the strontium-90 contaminant flux from groundwater to the river. In the target plume area, the net flux of groundwater to the river was estimated to be reduced by $\sim 96 \%$ (DOE-RL 1999a).

- Evaluation of the current treatment resin option (i.e., clinoptilolite) indicated that this medium is $>90 \%$ effective at removing strontium-90 from the extracted groundwater (DOE-RL 1997a).

- Strontium-90 ( 0.10 curies) was removed from the extracted groundwater during FY 1998, with a total of 0.29 curies removed since the system began operating in September 1995. An estimated 76 to 88 curies of strontium- 90 is believed present in the target groundwater plume and on saturated sediments (DOE-RL 1996).

\subsubsection{Other Groundwater Remediation Activities}

Interim remedial measures to address chromium in groundwater are being conducted at the 100-K Area (100-KR-4 Operable Unit) and at the 100-D/DR and 100-H Areas (100-HR-3 Operable Unit) using pump-and-treat systems. Strontium-90 is a co-contaminant in the groundwater plumes at $100-\mathrm{K}$ and $100-\mathrm{H}$ Areas being addressed by these pump-and-treat systems, although the systems do not remove strontium-90 from the extracted groundwater.

The highest observed strontium-90 concentration in groundwater extracted at the 100-K Area (i.e., influent to the treatment system) was $4.1 \mathrm{pCi} / \mathrm{L}$ during 1998 , with similar concentrations observed in the effluent, as expected (DOE-RL 1999c, p. 3.38). The source for that strontium-90 is past disposal to the 100-K Mile Long Trench (waste site 116-K-2 trench). The highest observed in the influent to the 100-HR-3 treatment system was 5.6 pCi/L during 1997 and 1998 (DOE-RL 1999c, p. 2.58), with a 
similar value listed for the effluent from the system. The source for strontium- 90 observed in the 100-HR-3 influent is the 107-H retention basin. Extraction well 199-H4-11, which is located adjacent to the basin, revealed strontium-90 at concentrations near 30 pCi/L during 1997 and 1998 (DOE-RL 1999c, p. 2.55).

Interim remedial actions are in progress at the 200-UP-1 and 200-ZP-1 groundwater operable units in the 200 West Area. However, strontium-90 is not a target contaminant for the current interim remedial actions (DOE-RL 1999a, pp. 2.1 to 3.14). The highest concentrations of strontium-90 in groundwater beneath the 200 Areas occur near 200 East at the former Gable Mountain Pond disposal site and immediately north of B Plant (Hartman 1999, Figure 3.195, p. 5.10-2). 


\subsection{Strontium-90 and Fall Chinook Salmon}

This section discusses the occurrence and distribution of fall chinook salmon redds in the Hanford Reach and briefly defines the important characteristics of salmon spawning habitat. Applicable standards for the assessment of salmon exposure to strontium- 90 are reviewed and compared with published risk assessments. Environmental and biological factors that influence exposure to strontium-90 and the associated biological response are addressed. Related dose rates and effects are compared to place in perspective the potential exposure of salmon eggs and sac fry in the Hanford Reach.

\subsection{Occurrence/Distribution in Redds of the Hanford Reach}

Fall chinook salmon (Oncorhynchus tshawytscha) spawning in the Hanford Reach has been monitored annually by aerial surveillance since 1948 (Dauble and Watson 1997). These surveys provide a relative measure of long-term population trends of fall chinook salmon, but they do not provide a comprehensive accounting of where all salmon spawn. Detecting spawning activity from an airplane is influenced by water depth, water clarity, weather conditions, and individual observer technique. Previous work suggests that the depth limit for detecting redds from the air is approximately 3 meters (Swan et al. 1998, p. 3). Although the aerial surveys appear to monitor the visible spawning areas in the Hanford Reach in a consistent manner, there may be additional, smaller spawning areas that are not accounted for in the aerial survey data.

\subsubsection{History of Spawning in the Reach}

As a result of dam construction within the Columbia Basin from 1933 to 1968, the Hanford Reach became the last free-flowing stretch of the Columbia River in the United States. The loss of mainstem habitat throughout the Basin led to an increase in spawning by chinook salmon within the Reach after 1959, the year Priest Rapids Dam was completed.

Salmon spawning nests, called redds, are counted in the Reach from the Vernita Bar area downstream to Richland (Figure 4.1). There are 10 salmon spawning areas identified in the Hanford Reach (Dauble and Watson 1990, pp. 3.3 to 3.4). The two most productive areas are at Vernita Bar (No. 10) and Upper Locke Island (No. 5). These two locations contributed 33\% and 25\%, respectively, to the total number of redds counted from 1948 through 1992 (Dauble and Watson 1997, p. 283). Vernita Bar is located upstream of the Hanford Site and Upper Locke Island is located near the 100-H Area (Figure 4.1).

The remaining eight spawning areas are near 100-D (No. 8), Ringold/Wooded Island (No. 1), Coyote Rapids (No. 9), the inside passage of Island No. 3 (No. 6), the north side of Island No. 3 (No. 7), 100-F Area (No. 3), and F Slough (No. 2). Salmon redd counts from the major spawning areas have generally increased since the completion of Priest Rapids Dam in 1959. To illustrate this, counts for 100-H Area and Vernita Bar, both of which are heavily used spawning areas, are compared to 100-D and Ringold/ Wooded Island (relatively low-use spawning areas) in Figure 4.2. 


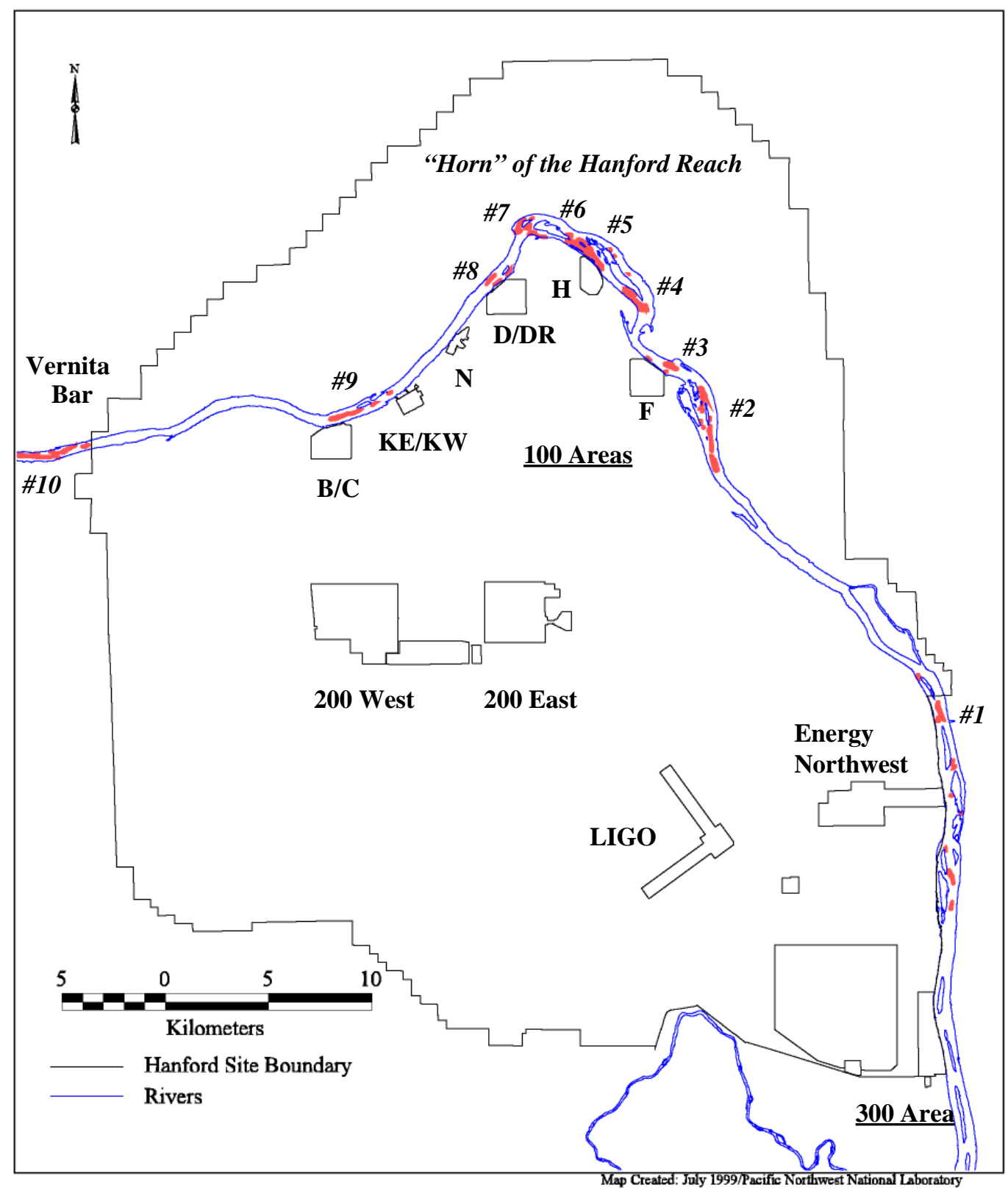

Fall Chinook Salmon Redd Areas

Figure 4.1. Major Fall Chinook Salmon Spawning Areas in the Hanford Reach 


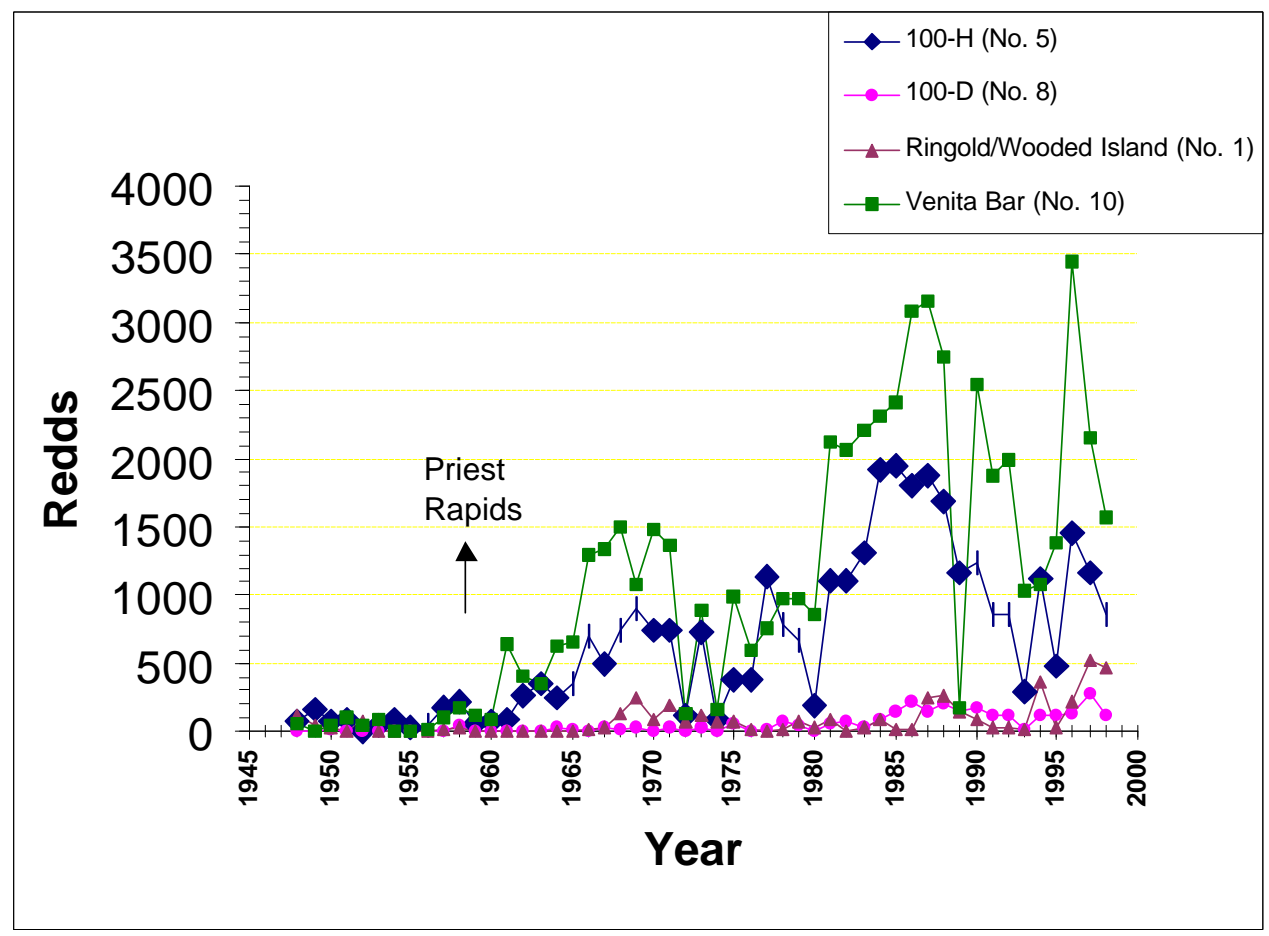

Figure 4.2. Salmon Redd Counts at Vernita Bar, 100-D, 100-H, and Ringold/Wooded Island Spawning Areas

\subsubsection{Spawning Areas and Groundwater Contamination}

Groundwater plumes containing chemical and radiological contamination have been identified at each of the 100 Area reactor sites (Hartman 1999, pp. 5.1 to 5.49; Dirkes and Hanf 1998, pp. 6.40 to 6.47). The 100-D spawning area (No. 8) and 100-H spawning area (No. 5) are the known spawning areas closest to known groundwater contaminant plumes associated with the Hanford Site. The groundwater plume beneath the 100-H Area contains some strontium-90; however, there is little or no strontium-90 associated with the groundwater that enters the river at 100-D/DR Area (see Section 3.0).

The strontium-90 plume at 100-F Area appears to intersect the shoreline downstream of the river channel substrate that supports known spawning at the 100-F spawning area (No. 3). However, most visible salmon redds at 100-F spawning area (No. 3) are located on the far side of the river, beyond where groundwater from the Hanford Site is believed to upwell into the channel (Visser 2000). The 100-F plume may, however, influence the region downstream of 100-F Area that is adjacent to F Slough spawning area (No. 2).

\subsection{Spawning Habitat Assessment}

Salmon spawning habitat is typically characterized by measuring water depth, water velocity, and substrate size (see Geist and Dauble [1998], for a summary of characterization methods). Although these 
features are useful in defining the boundaries for spawning habitat, spawning areas defined using only these characteristics often contain a large proportion of habitat that is not used. Recent research in the Hanford Reach and elsewhere is identifying the importance of geomorphic features in refining the definition of suitable spawning habitat.

\subsubsection{Hyporheic Flow}

Fall chinook salmon redds are generally aggregated into definite clusters in the Hanford Reach, even though there are other segments of the Hanford Reach that appear suitable for spawning based on river velocity, depth, and cobble size. Clusters of redds are found in areas with complex channels (e.g., near islands or bends in the river). Complex channel patterns create geomorphic bed formations that facilitate interstitial flow of mixed surface and groundwater (Figure 4.3). The actual mix of surface water and groundwater in this "hyporheic" zone is a function of the geomorphic bed forms, volume of regional groundwater discharge to the river, and the river stage (Geist and Dauble 1998).

Recent research in the Hanford Reach has investigated the relationship between fall chinook salmon spawning and hyporheic flow (Geist and Dauble 1998). Hyporheic discharge, composed of mostly river water, was prevalent in areas used for spawning by fall chinook salmon near Locke Island in the Hanford Reach. Hyporheic discharge dominated by water quality characteristics associated with groundwater (greater specific conductance) was prevalent in a non-spawning area found near Wooded Island. Substrate found in spawning areas was also more permeable than substrate within non-spawning areas. The physical and chemical gradients between hyporheic and surface waters were greater in spawning areas than in non-spawning areas, suggesting that these gradients, along with standard hydraulic features of river channels, may provide cues for adult salmon to locate suitable spawning areas.

Thus, in relation to contaminant exposure in the area where salmon currently are spawning, there may be a greater likelihood that groundwater is more diluted in the interstitial zone by surface water than in areas that do not support spawning. This observation provides a plausible argument for hydrological mitigation of potential exposure in areas where salmon currently spawn, and groundwater contamination is an issue. It is also possible that salmon may be avoiding groundwater flow.

\subsubsection{Chemotaxis and Strontium-90}

Chemotaxis is the response (i.e., avoidance or attraction) of an organism to a chemical stimulus. Concentrations of strontium-90 do not occur at levels above background stable strontium concentrations that would be perceptible to salmonids. As a worst case example, an 8,000 pCi/L solution of strontium-90 (a value frequently observed in groundwater from the $100-\mathrm{N}$ Area) can be converted to $0.000000056 \mu \mathrm{g} / \mathrm{L}$ strontium-90. The river background concentration for stable strontium is $100 \mu \mathrm{g} / \mathrm{L}$. In order for fish to be attracted to (or avoid) upwelling groundwater that contains $8,000 \mathrm{pCi} / \mathrm{L}$ strontium-90, they would have to be able to distinguish an increase in strontium of $0.0000056 \%$ over the background concentration of $100 \mu \mathrm{g} / \mathrm{L}$ strontium-90. The sensitivity (threshold) of salmon olfactory senses has been reported to be as low as $1 \times 10^{-8} \mu \mathrm{g} / \mathrm{L}$ for some organic compounds with no background concentration (Hasler 1957, pp. 204-205). On a gravimetric basis, the increase in strontium above background is so miniscule, that it is extremely unlikely that the difference could be perceived by salmon olfactory systems. 


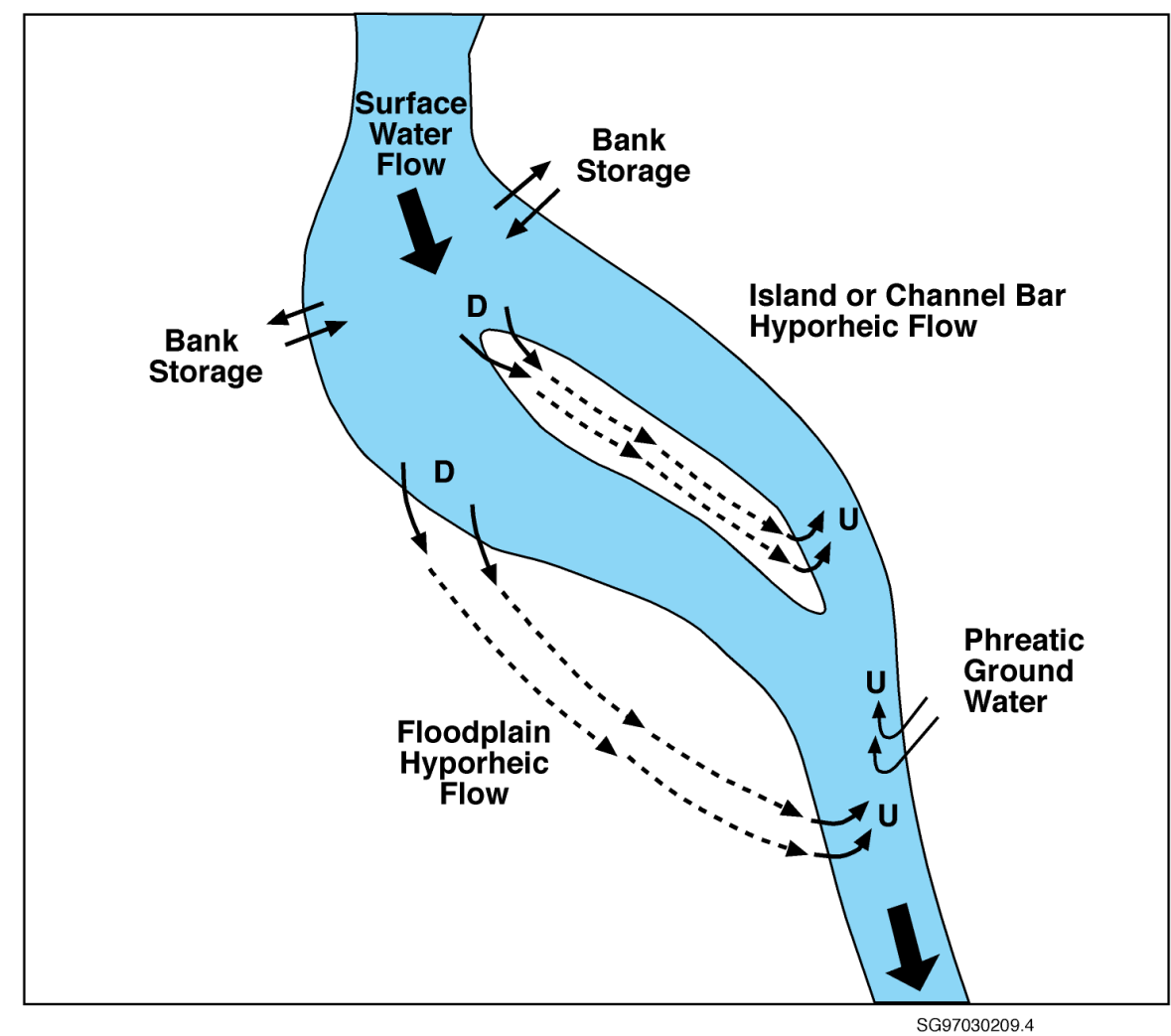

Figure 4.3. Conceptual Model for Hyporheic Flow in Hanford Reach Sediments

\subsubsection{Aquatic Fate/Behavior of Strontium-90}

Strontium is chemically similar to calcium. Consequently, strontium behaves like calcium in aqueous solutions. However, strontium does have a slightly higher propensity to sorb to sediment than calcium, but strontium is relatively mobile in groundwater and surface water systems. Fish have no dietary requirement for calcium, and their physiological need for calcium is met by direct absorption from water. Because of its similarity to calcium, strontium accumulates in hard bony tissue in fish. Body fluid levels of calcium are homeostatically maintained at a constant level in fish. The homeostatic concentration of strontium in fish is determined by the molar ratio of calcium to strontium. In aquatic systems with comparatively higher amounts of calcium, the amount of strontium accumulated is proportionately reduced. As fish start producing bone, the physiological demand for calcium increases. Accordingly, strontium is also adsorbed and deposited in fish bone and scales in proportionately higher amounts.

The concentration ratio (CR) for strontium-90 in fish flesh can be estimated by the following equation developed by Vanderploeg et al. 1975 (as reported in Poston and Klopfer 1986, p. 185).

$$
\mathrm{CR}(\mathrm{flesh})=e^{[5.18-1.21(\mathrm{ln} \text { Ca concentration in } \mathrm{mg} / \mathrm{L})]}
$$

The concentration ratio for strontium- 90 in bone can be estimated by the following equation developed by Vanderploeg et. al. 1975 (as reported in Poston and Klopfer 1986, p. 185). 


$$
\mathrm{CR}(\text { bone })=e^{[9.59-1.15(\mathrm{ln} \text { Ca concentration in } \mathrm{mg} / \mathrm{L})]}
$$

With a concentration of $17 \mathrm{mg} \mathrm{Ca} / \mathrm{L}$ in Columbia River water, the concentration ratios for flesh and bone are estimated at 5.7 and 560 respectively. This means that if the concentration of strontium-90 in water was $1 \mathrm{pCi} / \mathrm{L}$, the concentration in fish tissue would be $5.7 \mathrm{pCi} / \mathrm{kg}$ muscle, and the concentration in bone would be $560 \mathrm{pCi} / \mathrm{kg}$. This assessment will address dose to soft tissue as salmon embryos do not produce hard calcified tissue until after they emerge from the cobble riverbed.

\subsubsection{Developmental Considerations}

The egg-larval life stage is the most sensitive life stage of salmon. Development of salmonids in the egg and early life stages, commonly identified as sac fry, is dependent on temperature. Time to hatch estimates for chinook salmon range from 32 days at $16^{\circ} \mathrm{C}$ to 159 days for $3^{\circ} \mathrm{C}$ (Healey 1991). Chinook salmon generally have a 90-day cycle from the time eggs are fertilized through hatching and finally emergence from the river cobble into the river. Four assumptions were used to estimate the equilibrium concentration of strontium-90 and the corresponding dose in salmon eggs:

1. The concentration ratio of 5.7 for flesh can be applied to the whole egg, developing embryo, and sac fry (Healey 1991, pp. 313-393).

2. The concentration of strontium-90 in the interstitial water in the redd was based on the median observed concentration of $17 \mathrm{pCi} / \mathrm{L}$ observed in $100-\mathrm{H}$ riverbank seepage during the past 7 years (Dirkes and Hanf 1998, p. A.11).

3. When fertilized, the egg contains enough calcium to meet its immediate physiological needs.

4. Any additional physiological requirement for calcium will be met by adsorption from the surrounding water.

Based on a concentration of strontium- 90 of $17 \mathrm{pCi} / \mathrm{L}$ in the redds under these conditions, the dose to the egg-larval stage is $0.000009 \mathrm{rad} /$ day (Baker and Soldat 1992). Increased adsorption of calcium, and consequently strontium-90, during the sac-fry stage in the gravel, would not occur until just before emergence (estimated at day 85 to 90 at $9.5^{\circ} \mathrm{C}$ ), when calcification first starts to appear in head cartilage.

Calcification of the skeleton is complete at about 170 days post fertilization and well after the alevin has absorbed its yolk sac and left the redd. The point is that increased rates of calcium (and strontium-90) assimilation by the developing salmon does not occur until bone is laid down in cartilaginous structures (Figure 4.4). At this time, the juvenile salmon is emerging from the gravel, and exposure to the interstitial water is terminating. This relationship minimizes the bioaccumulation of strontium-90 during the majority of embryonic and sac-fry development.

Although this dose estimate is believed to be conservative for strontium-90, it does not consider other radionuclides that may be present in the spring water, nor does it consider any dilution in the redds as the groundwater diffuses into the cobble and mixes with surface water. Based on conductivity measures 
taken from the near-shore 100-H redds (Sample locations TH-1, Hope and Peterson 1996, p. 4-4, Table 4.2), the interstitial water in the redds was about $22 \%$ spring water and $78 \%$ surface water. Median concentrations of tritium, strontium-90, technetium-99, and uranium- 234, -235, -238 in 100-H spring water (Dirkes and Hanf 1998, p A.11) were adjusted for $22 \%$ dilution and used to model dose to the developing embryo. The resulting dose rate was $0.000021 \mathrm{rad} / \mathrm{day}$.

\subsubsection{Immersion Dose Rates}

For comparison, background immersion dose rates in the Columbia River in 1982 (the last year they were measured) were estimated at Coyote Rapids (Sula et al. 1983, p. 44). Hourly dose rates were reported at $0.005 \mathrm{mrem} / \mathrm{h}(0.12 \mathrm{mrem} /$ day $)$ or an annual dose of $43.8 \mathrm{mrem}$. This annual dose level is approximately 10 times the dose associated with the drinking water standard for strontium-90 to a human (i.e., $4 \mathrm{mrem} / \mathrm{year}$, or a concentration equivalent of $8 \mathrm{pCi} / \mathrm{L}$ ). Because of the continued decay of atmospheric weapons testing fallout, background immersion dose rates should be slightly less than the values last measured in 1982 . The $0.12 \mathrm{mrem} /$ day dose rate is equivalent to $0.00012 \mathrm{rad} /$ day and represents an approximation of the background dose rate for salmon embryos and sac fry in the Columbia River. 


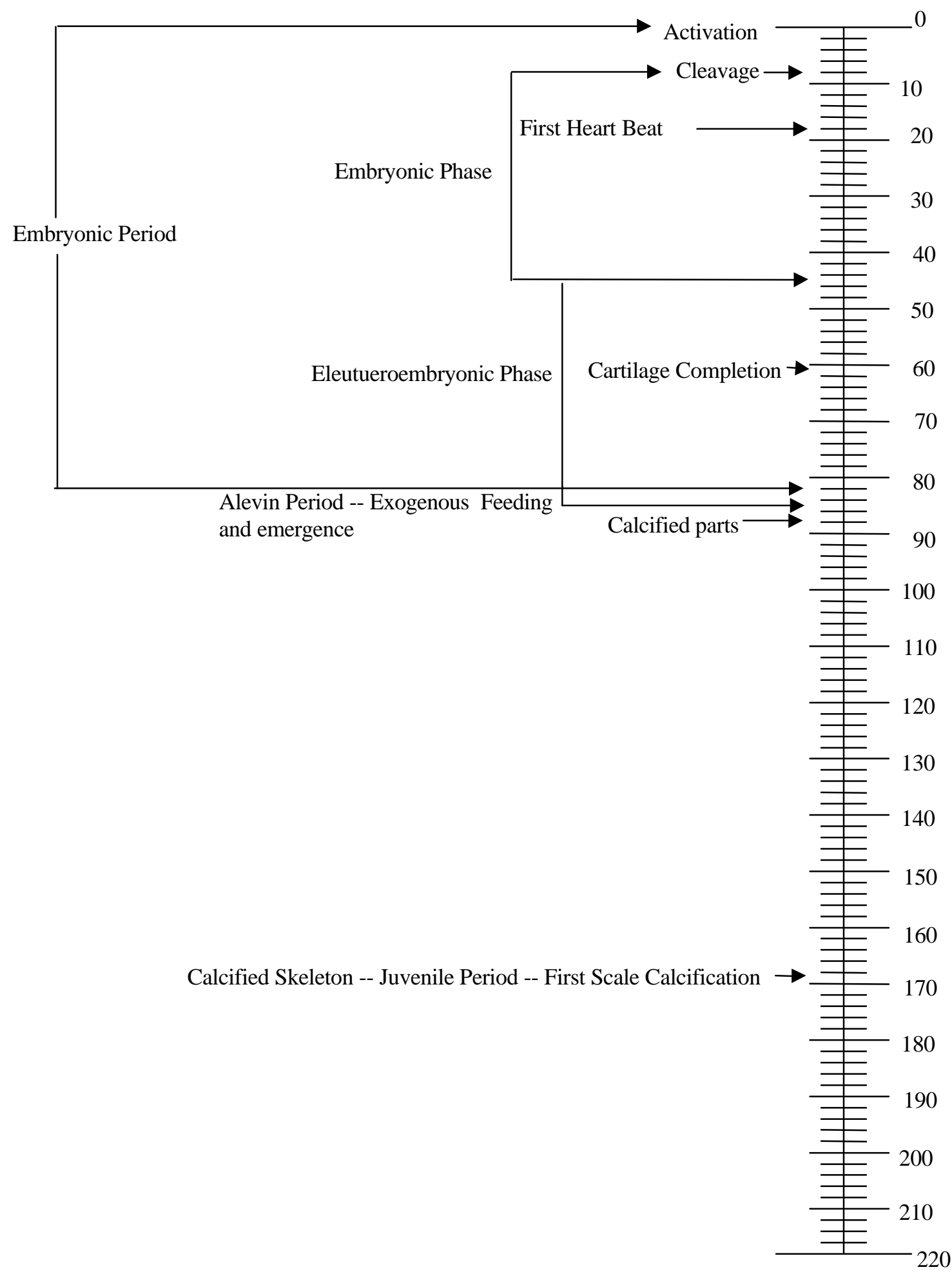

Figure 4.4. Development of Salmon at 9.5 Degrees Celsius 


\subsection{Strontium-90 Action Levels}

This section describes the regulatory standards and criteria used to set action levels for strontium-90. It includes a summary of previous risk assessments and regulatory decisions that have been made for strontium-90 at the Hanford Site.

\subsection{Applicable Standards and Measurements}

International, national, and state standards and measurements applicable to strontium-90 contamination include radiation dose limits and maximum contaminant levels for drinking water supplies and ambient water quality standards for the state of Washington.

\subsubsection{Aquatic Organism Dose Limit}

The dose rate of $1.0 \mathrm{rad} /$ day was initially proposed by the International Atomic Energy Agency (IAEA 1976, pp. 86 and 101). The guidance was based on the fact that the most radio-sensitive aquatic organisms were teleost (i.e., bony) fish, and that the most sensitive life stage was the developing eggs and larvae. The IAEA notes that some mortality was observed at acute doses of $100 \mathrm{rad}$, and that there were some minor physiological or metabolic effects associated with chronic dose rates of $1.0 \mathrm{rad} / \mathrm{day}$. They caution that most studies involved acute high-dose exposures and that data for low-dose chronic exposures were lacking. Their evaluation involved the review of 384 scientific studies from 1958 to 1974.

In 1991, the National Council on Radiation Protection and Measurements (NCRP) issued a report that addressed the effects of ionizing radiation on aquatic organisms. The report summarized the literature that was reviewed by IAEA (1976) as well as subsequent research that was published after 1974 (NCRP 1991, p. 2). The report describes in detail the pertinent literature on radiation effects to aquatic organisms with respect to acute and chronic exposures, both in the field and in laboratory studies. The major highlights of the NCRP report regarding radiation effects are summarized below.

1. Acute effects on fish ( $\mathrm{LD}_{50}$ exposures) occur at total doses of $1000 \mathrm{rad}$ or greater and have little relationship to environmental exposure levels. The lowest dose rate associated with an impact to fish, in this case silver salmon, was 15 rad dose to the single cell life stage (Bonham and Welander 1963, pp. 353 to 354). The result, however, is questionable, because of inadequate design and a $20 \%$ mortality rate associated with the corresponding control treatment. Other acute effects of radiation exposure to fish documented in the report were associated with doses ranging from 240 to 1,000 rad total dose (Figure 5.1). 


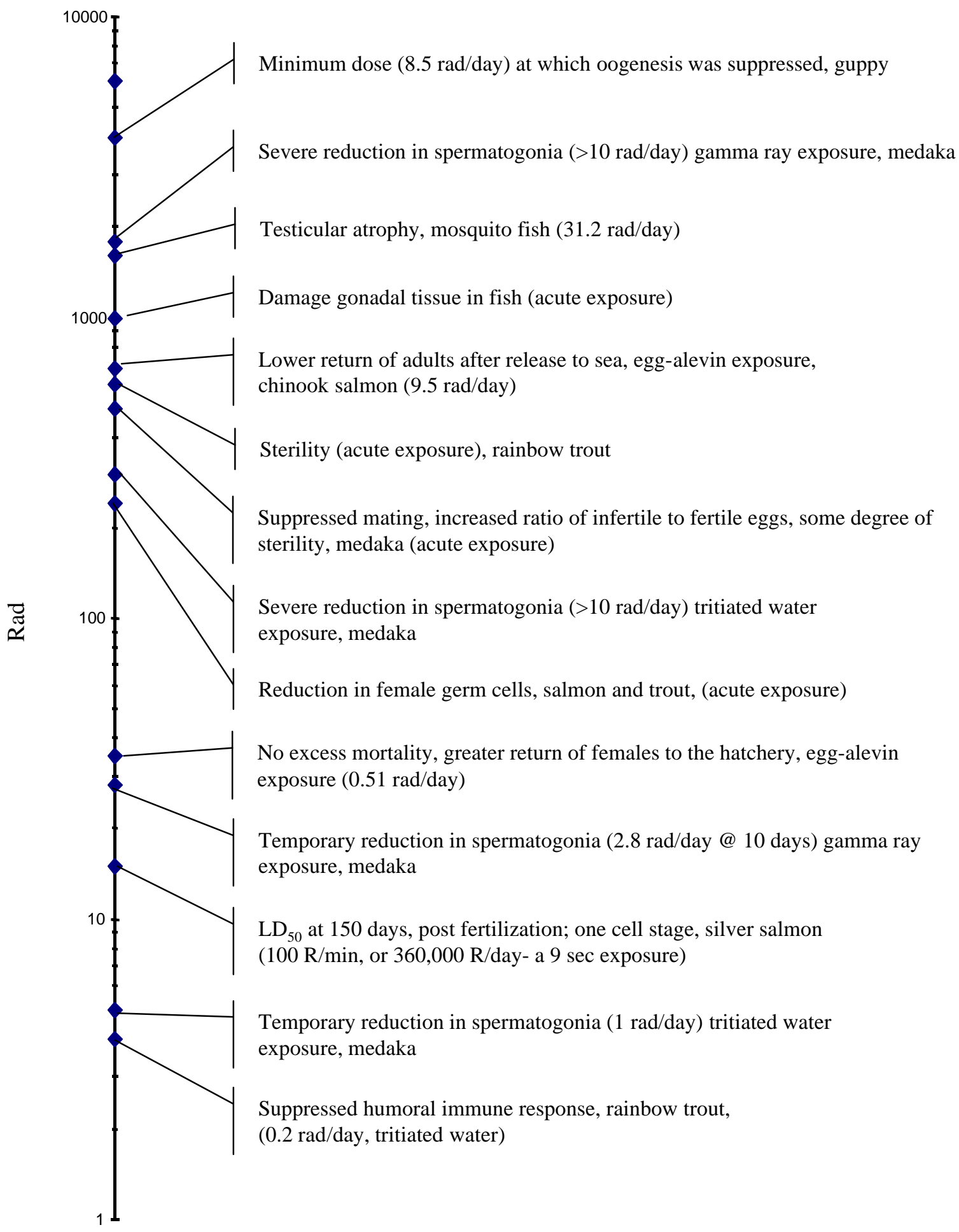

Figure 5.1. Total Radiation Dose (Rad) and Effects in Fish 
2. Chronic low level studies were also reviewed. Mortality, physiological effects, reproduction, growth and development were evaluated. For these categories, the following conclusions were drawn:

- Mortality. No mortality was observed at dose rates as low as $0.5 \mathrm{rad} /$ day embryonic-larval exposure of chinook salmon; however, the exposed fish were released and monitored as adults when they returned to the laboratory 4 years later. There was a reduced return of adults at $9.5 \mathrm{rad} / \mathrm{day}$ (NCRP 1991, p. 10).

- Physiological effects. The lowest reported effect was suppressed production of serum antibody in rainbow trout exposed to $4 \mathrm{rads}(0.2 \mathrm{rad} /$ day) during embryogenic exposure to tritiated water. Other effects ranges were from $1.0 \mathrm{rad} /$ day temporary depletion of spermatogonia in medaka) to $130 \mathrm{rad} /$ day (testicular atrophy in mosquito fish; NCRP 1991, p. 13).

- Reproductive effects. Gonadal development of smolts was retarded at $9.5 \mathrm{rad} /$ day in chinook salmon exposed during embryogenesis. A dose rate of $6.5 \mathrm{rad} /$ day increased sterility in medaka. Reduced fecundity was observed in guppy at $4 \mathrm{rad} /$ day (NCRP 1991, p. 16).

- Developmental effects. Increase in opercular defects (above the rate of incidence in controls) in silver salmon was observed at $0.42 \mathrm{rad} /$ day. Increased growth was observed in chinook salmon smolts at $0.51 \mathrm{rad} /$ day; a decrease in growth was noted at $9.5 \mathrm{rad} /$ day in chinook salmon (NCRP 1991, p. 21).

- Mutation rate. Increase in abnormalities in rainbow trout was observed at $25 \mathrm{rad}$; a dose of $54 \mathrm{rad}$ would double the frequency of abnormalities (NCRP 1991, p. 34).

The NCRP concluded that $1 \mathrm{rad} /$ day as a maximally exposed dose to an individual in a population would ensure protection of the population (NCRP 1991, p. 62). NCRP also identified a "trigger level" of $0.25 \mathrm{rad} /$ day as a modeled dose rate at which a more detailed evaluation should be conducted for possible environmental exposure.

In 1992, the IAEA issued a second report that addressed more specifically the development of radiation protection standards for plants and animals (IAEA 1992). The report also specifies a dose rate of $1.0 \mathrm{rad} /$ day for the protection of populations of aquatic organisms. It also notes that compliance with radiation protection standards that have been adopted for the protection of humans will ensure that the higher proposed guidance levels for terrestrial ( $0.1 \mathrm{rad} /$ day $)$ and aquatic (1.0 rad/day) biota will not be exceeded. As an independent international body, IAEA further documents and corroborates the NCRP recommendation of a $1.0 \mathrm{rad} /$ day guideline.

Last, the $1.0 \mathrm{rad} /$ day guideline for aquatic organisms is adopted in DOE Order 5400 and is under review for codification as CFR 834. 


\subsubsection{EPA Drinking Water Standard/State of Washington Ambient Water Quality Standards}

Comparisons of environmental concentrations of contaminants are often made with drinking water standards because they are among the first promulgated standards. The drinking water standard for strontium-90 is $8 \mathrm{pCi} / \mathrm{L}$ and is based on bone as the critical organ. The basis for the drinking water standard is the dose received by a 150-pound human that would result from drinking 2 liters per day for 365 days. This amounts to an annual intake of 5,840 pCi. The resulting dose is 4 mrem per year.

This standard is relevant to drinking water supplies. However, it is inappropriate to apply this standard to ecological exposures where populations of aquatic organisms are concerned. Nonetheless, the only way to compare the drinking water standard to the aquatic organism dose guideline is to convert it to a daily dose rate. The converted daily dose rate is $0.000011 \mathrm{rem} / \mathrm{day}$. For this comparison, a rem equals a rad.

Similarly, the state ambient water quality standards for radioactive materials also specify the drinking water standard under the NCPP premise that concentrations protective of human health will be protective of populations of aquatic life.

\subsubsection{0-N Area Special Study}

In 1997, PNNL and the Washington State Department of Health conducted a study at N Springs in the 100-N Area. The objective of the study was to evaluate the riparian and near-shore environs under conditions that would exacerbate exposure of resident aquatic organisms and human activities near the site to contaminants. Riverbank seeps along the 100-N shoreline have the highest concentrations of strontium-90 of any other riverbank seeps at Hanford. Maximum concentrations reached 11,000 pCi/L during the past 6 years (Dirkes and Hanf 1998, p. A.11).

The study was conducted during late summer, when low river flows minimized the effect of dilution of seepage by river water, thus providing an opportunity to observe maximum exposure levels. Salmon do not spawn in this section of the river. Dose assessments were performed for other aquatic organisms at the site. A composite sample of sculpin contained a whole body burden of $0.75 \mathrm{pCi} / \mathrm{g}$ strontium- 90 (Van Verst et al. 1998, p. 6.1). The resulting dose from this body burden was $0.00008 \mathrm{rad} / \mathrm{day}$. In the overall aquatic dose modeling, no aquatic organism exceeded the $1.0 \mathrm{rad} / \mathrm{day}$ dose limit (Van Verst et al. 1998, p. 6.3).

\subsection{Risk Assessments and Decisions}

Risk assessments conducted at the Hanford Site that analyzed strontium-90 include a comprehensive analysis of chemical and radiological contaminants in the river environment at the Site and limited field investigations of groundwater operable units near the river. 


\subsubsection{CRCIA Risk Assessment}

The DOE initiated the Columbia River Comprehensive Impact Assessment (CRCIA) in 1995 (DOE 1998a). One objective of CRCIA was to determine whether Hanford-derived contaminants currently in the study area (the aquatic and riparian zones from Priest Rapids to McNary dams) posed a significant risk to ecological and human receptors. To approach this question, the study area was segmented into zones corresponding to known groundwater plumes entering or located near the Columbia River, and to sediment data within the river itself. Media concentration data were derived from groundwater, seep, sediment, and surface water monitoring data from a wide variety of sources, including those outside DOE and its contractors. Ecological receptors that were evaluated included steelhead and salmon (eggs, larvae, and adults), as well as over 40 other species found in the aquatic and riparian environments.

For all species and life stages, risks were evaluated for all available exposure pathways, including ingestion (as appropriate), dermal, and respiratory exposures. Contaminants of potential concern included strontium-90. Exposures were estimated in two ways: by using 1) maximum observed concentrations within each environmental medium in each segment, and 2) the distribution of concentrations observed in each medium in each segment. Method 1) was used to estimate exposures at "hot spots," while Method 2) reflected the range of exposures possible within a given segment. Estimated exposures were compared to lowest observed adverse effects levels for each species. Media concentration data, exposure methodology, and toxicological benchmarks for the assessment were all reviewed and approved by the CRCIA management team, which included DOE, the Confederated Tribes of the Umatilla Indian Reservation, Nez Perce Tribe, Yakama Nation, Hanford Advisory Board, Oregon State Department of Energy, EPA, and Ecology.

The ecological assessment found no risks from strontium-90 in the vicinity of $\mathrm{H}$ reactor area (segments 9 and 10 in the CRCIA report: DOE 1998a, pp. I-4.79) either at hot spots or from more widely distributed contamination for any terrestrial or aquatic species. No life stage of salmon or steelhead was found to be at risk from strontium-90 in groundwater, seeps, or sediment; neither were prey of these or other species. Strontium-90 at the N Springs was identified as a potential "temporary or spatially limited hot spot" with the estimated risk above the levels associated with the upstream control segment.

\subsubsection{Limited Field Investigations}

As part of the CERCLA process, limited field investigations were conducted for each groundwater operable unit identified on the Hanford Site. The limited field investigations for near-river operable units used groundwater data collected during 1992 and 1993 and identified contaminants of potential concern. The limited field investigation process included a qualitative risk assessment, the results of which were used to make decisions regarding the need for interim remedial actions. A summary of the conclusions and recommendations made during the limited field investigation process is presented in Table 5.1.

Based on the qualitative risk assessment, contaminants of concern were identified considering human health risks and ecological risks. Strontium-90 appeared as a contaminant of concern for human health risk at the 100-B/C, 100-N, 100-D/DR, 100-H, and 100-F Areas. Strontium-90 was identified as a 
Table 5.1. Results of Qualitative Risk Assessments Performed as Part of the Limited Field Investigations (LFI) under CERCLA, 1991-1994

\begin{tabular}{|c|c|c|c|}
\hline $\begin{array}{l}\text { Groundwater } \\
\text { Operable Unit }\end{array}$ & $\begin{array}{l}\text { Human Health } \\
\text { Risk }\end{array}$ & Ecological Risk & $\begin{array}{l}\text { Limited Field Investigation Conclusions and } \\
\text { Recommendations }\end{array}$ \\
\hline $\begin{array}{l}\text { 100-BC-5 } \\
(\text { DOE-RL 1994e) }\end{array}$ & $\begin{array}{l}\text { Carbon-14 } \\
\text { Strontium-90 } \\
\text { Technetium-99 } \\
\text { Tritium }\end{array}$ & $\begin{array}{l}\text { Aluminum } \\
\text { Chromium } \\
\text { Iron } \\
\text { Nickel }\end{array}$ & $\begin{array}{l}\text { An IRM is not required because of the low risk } \\
\text { associated with current site usage. Remove from } \\
\text { IRM pathway. Continue monitoring until source } \\
\text { remediations are complete, then re-evaluate risk. }\end{array}$ \\
\hline $\begin{array}{l}\text { 100-KR-4 } \\
\text { (DOE-RL 1994b) }\end{array}$ & $\begin{array}{l}\text { Arsenic } \\
\text { Carbon-14 } \\
\text { Chromium } \\
\text { Nitrate } \\
\text { Tritium }\end{array}$ & $\begin{array}{l}\text { Chromium } \\
\text { Carbon-14 } \\
\text { Iron } \\
\text { Lead } \\
\text { Silver } \\
\text { Zinc }\end{array}$ & $\begin{array}{l}\text { An IRM is not indicated on the basis of human } \\
\text { health or ecological risk. Continue on IRM } \\
\text { pathway, however. } \\
\text { *Analysis of subsequent data concluded that } \\
\text { ecological risk from chromium warranted interim } \\
\text { remedial measures. }\end{array}$ \\
\hline $\begin{array}{l}\text { 100-NR-2 } \\
\text { (DOE-RL 1995a) }\end{array}$ & $\begin{array}{l}\text { Arsenic } \\
\text { Cadmium } \\
\text { Chromium } \\
\text { Fluoride } \\
\text { Manganese } \\
\text { Nitrate } \\
\text { Tritium } \\
\text { Strontium-90 }\end{array}$ & $\begin{array}{l}\text { Cadmium } \\
\text { Chromium } \\
\text { Iron } \\
\text { Strontium-90 } \\
\text { Zinc }\end{array}$ & $\begin{array}{l}\text { An IRM is not recommended until after the expe- } \\
\text { dited response action to address strontium- } 90 \text { is } \\
\text { implemented. Re-evaluate COPCs at that time. }\end{array}$ \\
\hline $\begin{array}{l}\text { 100-HR-3(D) } \\
\text { (DOE-RL 1994c) }\end{array}$ & $\begin{array}{l}\text { Chromium } \\
\text { Nitrate } \\
\text { Strontium-90 } \\
\text { Tritium }\end{array}$ & $\begin{array}{l}\text { Chromium } \\
\text { Sulfide }\end{array}$ & $\begin{array}{l}\text { An IRM is not indicated on the basis of human } \\
\text { health or ecological risk. Continue RI/FS process. } \\
\text { *Analysis of subsequent data concluded that } \\
\text { ecological risk from chromium warranted interim } \\
\text { remedial measures. }\end{array}$ \\
\hline $\begin{array}{l}\text { 100-HR-3(H) } \\
(\text { DOE-RL 1994c) }\end{array}$ & $\begin{array}{l}\text { Americium-241 } \\
\text { Carbon-14 } \\
\text { Chromium } \\
\text { Chloroform } \\
\text { Nitrate } \\
\text { Strontium-90 } \\
\text { Technetium-99 } \\
\text { Tritium } \\
\text { Uranium } \\
\end{array}$ & $\begin{array}{l}\text { Chromium } \\
\text { Sulfide }\end{array}$ & $\begin{array}{l}\text { An IRM is not indicated on the basis of human } \\
\text { health or ecological risk. Continue the RI/FS } \\
\text { process. } \\
* \text { Analysis of subsequent data concluded that } \\
\text { ecological risk from chromium warranted interim } \\
\text { remedial measures. }\end{array}$ \\
\hline $\begin{array}{l}\text { 100-FR-3 } \\
\text { (DOE-RL 1994f) }\end{array}$ & $\begin{array}{l}\text { Arsenic } \\
\text { Chromium } \\
\text { Manganese } \\
\text { Nitrate } \\
\text { Strontium-90 } \\
\text { Tritium }\end{array}$ & $\begin{array}{l}\text { Chromium } \\
\text { Copper } \\
\text { Lead }\end{array}$ & $\begin{array}{l}\text { An IRM is not indicated by human health or eco- } \\
\text { logical risk. Continue on IRM pathway; continue } \\
\text { RI/FS process. Trichloroethylene, while not a risk } \\
\text { driver, exceeds a potential applicable or relevant } \\
\text { and appropriate requirement. }\end{array}$ \\
\hline
\end{tabular}


contaminant of concern for ecological risk only at the 100-N Area. The risk at 100-N was associated with ingestion of strontium-90 by plant-eating ducks. An expedited response action under CERCLA was initiated to address strontium-90 contamination (DOE-RL 1994d).

\subsubsection{0-N Expedited Response Action}

The action to address strontium-90 contamination at the 100-N Area was undertaken as a "non-timecritical" removal action that is intended to substantially reduce the flux of strontium-90 to the river (DOE-RL 1994d, pp. 1.1 to 1.2). The basis for the action was the presence of relatively large amounts of strontium-90 in the groundwater beneath past-practices disposal facilities. The action was not proposed as a final remedial action for the 100-NR-2 Operable Unit, and the decision to proceed was based on considerations in addition to those resulting from assessment of risk.

An action memorandum sent by Ecology and EPA to the DOE (Ecology and EPA 1994) ${ }^{(a)}$ contained three expedited response action goals:

- reduce the strontium-90 contamination flux to the river

- evaluate commercially available treatment options for strontium-90

- provide data necessary to set demonstrable strontium-90 groundwater cleanup standards.

The experience gained by operating the pump-and-treat system at $100-\mathrm{N}$ will be used in making future decisions with regard to the need for interim remedial actions and the final record-of-decision for environmental restoration at the 100-NR-2 Operable Unit.

(a) Washington State Department of Ecology (Ecology) and U.S. Environmental Protection Agency (EPA). 1994. Action Memorandum: N-Springs Expedited Response Action Cleanup Plan, U.S. Department of Energy Hanford Site, Richland, Washington. Letter to R. Izatt (DOE-RL) from D. Butler (Ecology) and R. F. Smith (EPA), dated September 23, 1994, Washington State Department of Ecology and U.S. Environmental Protection Agency, Olympia, Washington. 


\subsection{Discussion}

This section discusses issues associated with strontium-90 in the Hanford environment, including estimates of environmental doses to salmon. Recommendations concerning the need to initiate new actions with respect to monitoring and remedial actions associated with strontium-90 contamination at the Hanford Site are provided.

\subsection{Residual Contamination and Potential Future Sources}

The contamination that currently is observed in groundwater near the Columbia River has resulted from disposal activities and unplanned spills/leakage that generally ceased in the mid-1960s. Approximately 40 years have gone by, during which time plumes have moved with groundwater flow, dispersed, and undergone radioactive decay. The highest concentrations for plumes of mobile constituents created during the operating years may now be located on the river side of monitoring wells or already in the river. For less mobile constituents, such as strontium-90, concentrations may decline primarily as a result of radioactive decay or because of advective flow with groundwater.

Near the Columbia River, there is no active disposal of radioactive waste that would serve as a source for the strontium-90 currently observed in groundwater. There are, however, zones of vadose zone contamination beneath 1) former liquid waste disposal facilities, and 2) unintentional leakage sites. These zones contain strontium-90 that is adsorbed to soil particles or possibly dissolved in pore space moisture. A change to saturated conditions in these zones would remobilize the stored strontium-90 and move it downward to groundwater.

Two general categories of events might lead to temporary saturation of currently unsaturated zones of contamination. The first is a rise in the water table. This occurs primarily in response to high river stage. The vadose zone/groundwater interface has reached a sort of equilibrium with respect to strontium-90 under the typical variability in water table elevation caused by the daily rise and fall of the river. However, unusually wet seasons cause a higher than normal water table, and it remains higher for longer than normal. This occurred at the Hanford Site during 1996 and 1997 (and to a lesser extent in 1999).

Remobilization of strontium-90 in response to the raised water table during 1996 and 1997 at the 100-N Area is well documented (DOE-RL 1998c, pp. 2.12 to 2.15). The analysis presented in that report suggests a 50\% increase in the amount of strontium-90 in the aquifer as a consequence of remobilizing strontium normally held in the vadose zone (DOE-RL 1998c, Table 2.2).

A second category of event that may remobilize strontium-90 held in the vadose zone is infiltration of water from the surface. The climate for the Hanford Site includes very low precipitation (and infiltration) on the average; however, thunderstorm events and rapid snowmelt can produce a localized pulse of mois-

ture. Under special conditions (e.g., open excavations and pathways down unsealed boreholes), moisture could infiltrate to greater than normal depths in the vadose zone. Characterization work to date has not documented this process, although it is plausible. 
Release of significant quantities of water to the surface may also occur during dust control operations and fire utility line maintenance, or leaks from fire utility lines. If this occurs at locations overlying underground contamination, the potential for remobilizing contaminants exists. An example of leaking fire utility lines causing remobilization of strontium-90 is believed to exist near well 199-K-109A in the 100-K Area (Johnson et al. 1998, p. 2.20). A second example of infiltration of surface water down to the aquifer occurred near the 105-D reactor, where a major utility line leak, along with possible uncontrolled release from a fire hydrant, caused significant dilution of groundwater beneath the site, as shown by monitoring results from well 199-D5-15.

\subsection{Estimate of Environmental Dose to Salmon}

Using the concentration ratio of 5.7 for salmon embryos and sac fry, the estimated dose to the eggs assuming a concentration of $17 \mathrm{pCi} / \mathrm{L}$ in the interstitial water (no dilution) is $0.000009 \mathrm{rad} / \mathrm{day}$. Multiply this by 90 days and the corresponding dose is $0.00081 \mathrm{rad}$ attributable to strontium- 90 with no dilution of the seep water. Accounting for dilution in the near-shore redds and including all major radiological contaminants in the 100-H spring water provides a more realistic estimate of dose. This dose rate attributable to the $100-\mathrm{H}$ springs $(0.000021 \mathrm{rad} /$ day $)$ is less than $0.175(18 \%)$ of the background immersion dose rate that was last measured in 1982 (Figure 6.1).

These observations are consistent with past risk assessments conducted in the Hanford Reach and specifically at the 100-N Area. The estimated doses are well below the applicable standard of $1.0 \mathrm{rad} / \mathrm{day}$ and the "trigger" level of $0.25 \mathrm{rad} /$ day proposed by NCRP 1991. The lowest dose rate associated with a negative effect has been the studies looking at immuno-suppression where a dose rate of $0.2 \mathrm{rad} / \mathrm{day}$ had a measurable effect on the production of serum antibody. A more detailed discussion of the immunosuppression studies is found in Appendix C. These studies are reviewed in more detail because they represent the lowest effects studies with radiation in fish.

In the most recent assessment, IAEA (1992) concluded that as long as dose rates fell below levels judged protective of human populations, the populations of aquatic organisms would also be protected. There are currently two dose levels used for the protection of human populations, the $100 \mathrm{mrem} / \mathrm{year}$ dose presently specified by DOE Order 5400, and the 15 to 25 mrem annual dose that is under consideration for 40 CFR 834.

Lastly, there are 10 major salmon spawning areas identified in the Hanford Reach. Only those near the 100-D/DR and 100-H Areas are presumed to be very close to or within riverbed areas where contaminated groundwater upwells into potential habitat. Strontium-90 is not present in the contaminant plumes at 100-D/DR Area. Fall chinook salmon infrequently spawn near the 100-F Area shoreline, but these areas do not appear to be influenced by the 100-F Area strontium-90 plume.

The number of redds that potentially may be exposed to diluted contaminated seep water is likely to be small and located close to the shoreline at the 100-H Area. Most salmon redds identified in the 100-D/DR Area are located on the north side of the river channel and are not likely to be exposed to contaminated Hanford groundwater that upwells into the river channel. Consequently, the estimated number of redds 


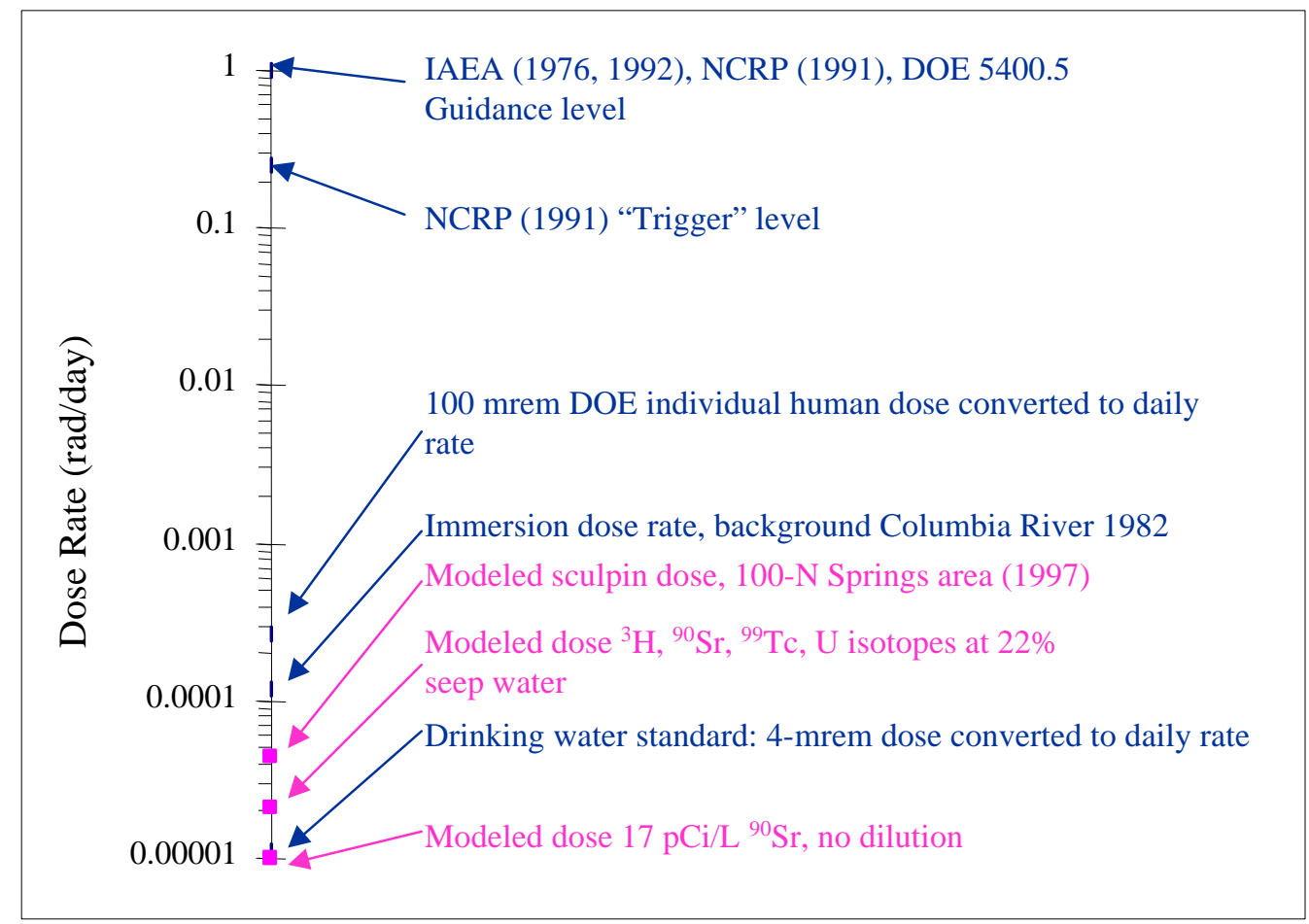

Figure 6.1. Reference Dose Rates and Modeled Dose Rates

actually exposed is a small fraction of the total redds near the 100-H Area. The very small number of redds exposed, and the low dose associated with that exposure $(0.000021 \mathrm{rad} / \mathrm{day}$, about 50,000 times lower than the $1.0 \mathrm{rad} /$ day limit) indicates that the exposure conditions near the $100-\mathrm{H}$ Area are not likely to constitute an unacceptable risk to salmon spawning at 100-H Area specifically, and within the Hanford Reach in general. 


\subsection{References}

Baker, D. A., and J. K. Soldat. 1992. Methods for Estimating Doses to Organisms from Radioactive Materials Released into the Aquatic Environment. PNL-8150, Pacific Northwest National Laboratory, Richland, Washington.

Bonham, K., and A. D. Welander. 1963. "Increase in Radioresistance of Fish to Lethal Doses with Advancing Embryonic Development." In: Schultz, V. and A. W. Klement, Jr., (eds.) Radioecology, Rheinhold Publishing, New York, and The American Institute of Biological Sciences, Washington, D.C.

Brown, D. J. 1963. Status of the Groundwater Beneath Hanford Reactor Areas: January 1962 to January 1963. HW-77170, General Electric Company, Hanford Atomic Products Operation, Richland, Washington.

Carpenter, R. W. 1993. 100-D Area Technical Baseline Report. WHC-SD-EN-TI-181, Rev. 0, Westinghouse Hanford Company, Richland, Washington.

Carpenter, R. W., and S .L. Cotè. 1994. 100-K Area Technical Baseline Report. WHC-SD-EN-TI-239, Rev. 0, Westinghouse Hanford Company, Richland, Washington.

Carpenter, R. W., S. L. Cotè, D. H. Deford, and M. W. Einan. 1994. 100-B/C Area Technical Baseline Report. WHC-SD-EN-TI-220, Rev. 0, Westinghouse Hanford Company, Richland, Washington.

Cotè, S. L. 1994. 100-N Technical Baseline Report. WHC-SD-EN-TI-251, Rev. 0, Westinghouse Hanford Company, Richland, Washington.

Dauble, D. D., and D. G. Watson. 1997. Status of Fall Chinook Salmon Populations in the MidColumbia River, 1948-1992. North American Journal of Fisheries Management, Vol. 17, No. 2.

Deford, D. H. 1993. 100-F Reactor Site Technical Baseline Report Including Operable Units 100-FR-1 and 100-FR-2. WHC-SD-EN-TI-169, Rev. 0, Westinghouse Hanford Company, Richland, Washington.

Deford, D. H., and M. W. Einan. 1995. 100-H Area Technical Baseline Report. BHI-00127, Rev. 00, Bechtel Hanford, Inc., Richland, Washington.

Dirkes, R. L., and R. W. Hanf (eds.). 1998. Hanford Site Environmental Report for Calendar Year 1997. PNNL-11795, Pacific Northwest National Laboratory, Richland, Washington.

Dirkes, R. L., R. W. Hanf, and T. M Poston (eds.). 1999. Hanford Site Environmental Report for Calendar Year 1998. PNNL-12088, Pacific Northwest National Laboratory, Richland, Washington.

Dorian, J. J., and V. R. Richards. 1978. Radiological Characterization of the Retired 100 Areas. UNI-946, Revised June 1981, United Nuclear Industries, Inc., Richland, Washington. 
Geist, D. R., and D. D. Dauble. 1998. "Redd Site Selection and Spawning Habitat Use by Fall Chinook Salmon: The Importance of Geomorphic Features in Large Rivers." Environmental Management 22(5):655-669.

Haney, W. A. (ed.). 1967. Final Report on the Effects of Ben Franklin Dam on Hanford. BNWL-412, Pacific Northwest Laboratory, Richland, Washington.

Hartman, M. J., L. M. Morasch, and W. D. Webber (eds.). 1999. Hanford Site Groundwater Monitoring for Fiscal Year 1998. PNNL-12086, Pacific Northwest National Laboratory, Richland, Washington.

Hartman, M. J. (ed.). 2000. Hanford Site Groundwater Monitoring for Fiscal Year 1999. PNNL-13116, Pacific Northwest National Laboratory, Richland, Washington.

Harty, H. 1979. The Effects of the Ben Franklin Dam on the Hanford Site. PNL-2821, Pacific Northwest Laboratory, Richland, Washington.

Hasler, A. D. 1957. “Olfactory and Gustatory Senses of Fishes.” In: M. E. Brown (ed.), The Physiology of Fishes, Vol. 2-Behavior. Academic Press, New York.

Healey, M. C. 1991. "Life History of Chinook Salmon (Oncorhynchus tshawytscha)." In: C. Groot and L. Margolis (eds.), Pacific Salmon Life Histories. University of British Columbia Press, Vancouver, B.C., pp. 313-393.

Hope, S. J., and R. E. Peterson. 1996. Chromium Concentrations in 100-H Operable Unit Pore Water Within Chinook Salmon Spawning Habitat of the Hanford Reach, Columbia River. BHI-00345, Rev. 0, prepared by CH2M Hill Hanford, Inc. for Bechtel Hanford, Inc., Richland, Washington.

International Atomic Energy Agency (IAEA). 1976. Effects of Ionizing Radiation on Aquatic Organisms and Ecosystems. IAEA-TECDOC-172, IAEA, Vienna, Austria.

International Atomic Energy Agency (IAEA). 1992. Effects of Ionizing Radiation on Plants and Animals at Levels Implied by Current Radiation Protection Standards. IAEA-TECDOC-332, IAEA, Vienna, Austria.

Johnson, V. G., C. J. Chou, M. J. Hartman, and W. D. Webber. 1998. Groundwater Monitoring for the 100-K Area Fuel Storage Basins: July 1996 Through April 1998. PNNL-12023, Pacific Northwest National Laboratory, Richland, Washington.

National Council on Radiation Protection and Measurements (NCRP). 1991. Effects of Ionizing Radiation on Aquatic Organisms. NCRP report No. 109, NCRP, Bethesda, Maryland. 
Perkins, C. J., A. R. Johnson, B. M. Markes, S. M. McKinney, and R. M. Mitchell. 1998. Hanford Site Near-Facility Environmental Monitoring Annual Report, Calendar Year 1997. HNF-EP-0573-6, prepared by Waste Management Federal Services, Inc. for Fluor Daniel Hanford, Inc., U.S. Department of Energy, Richland, Washington.

Perkins, C. J., B. M. Markes, J. M. McKinney, R. M. Mitchell, and R. C. Roos. 1999. Hanford Site Near-Facility Environmental Monitoring Data Report for Calendar Year 1998. PNNL-12088, Appendix 2, Pacific Northwest National Laboratory, Richland, Washington.

Peterson, R. E., and V. G. Johnson. 1992. Riverbank Seepage of Groundwater Along the Hanford Reach of the Columbia River, Washington. WHC-EP-0609, Westinghouse Hanford Company, Richland, Washington.

Peterson, R. E., J. V. Borghese, and D. B. Erb. 1998. Aquifer Sampling Installation Completion Report: 100 Area and Hanford Townsite Shorelines. BHI-01153, Rev. 0, prepared by CH2M Hill Hanford, Inc. for Bechtel Hanford, Inc., Richland, Washington.

Poston, T. M., and D. C. Klopfer. 1986. A Literature Review of the Concentration Ratios of Selected Radionuclides in Freshwater and Marine Fish. PNL-5484, Pacific Northwest Laboratory, Richland, Washington.

Poston, T. M., and J. K. Soldat. 1992. Scoping Assessment of Radiological Doses to Aquatic Organisms and Wildlife-N Springs. PNL-8360. Pacific Northwest Laboratory, Richland, Washington.

Sula, M. J., W. D. McCormack, R. L. Dirkes, K. R. Price, and P. A. Eddy. 1982. Environmental Surveillance at Hanford for CY 1981. PNL-4221, Pacific Northwest Laboratory, Richland, Washington.

Sula, M. J., J.M.V. Carlile, K. R. Price, and W. D. McCormack. 1983. Environmental Surveillance at Hanford for CY 1982. PNL-4657, Pacific Northwest Laboratory, Richland, Washington.

Swan, G. A. E. M. Dawley, R. D. Ledgerwood, W. T. Norman, W. F. Cobb, and D. T. Hartman. 1998. Distribution and Relative Abundance of Deep-Water Redds for Spawning Fall Chinook Salmon at Selected Study Sites in the Hanford Reach of the Columbia River. National Oceanic and Atmospheric Administration, National Marine Fisheries Service, Seattle, Washington.

U.S. Department of Energy, Richland Operations Office (DOE-RL). 1994a. Phase I Remedial Investigation Report for the 300-FF-5 Operable Unit. DOE/RL-93-21, Rev. 0, Vol. 2, U.S. Department of Energy, Richland, Washington.

U.S. Department of Energy, Richland Operations Office (DOE-RL). 1994b. Limited Field Investigation Report for the 100-KR-4 Operable Unit. DOE/RL-93-79, Rev. 0, prepared by IT Corporation for Westinghouse Hanford Company, U.S. Department of Energy, Richland, Washington. 
U.S. Department of Energy, Richland Operations Office (DOE-RL). 1994c. Limited Field Investigation Report for the 100-HR-3 Operable Unit. DOE/RL-93-43, Rev. 0, prepared by IT Corporation for Westinghouse Hanford Company, U.S. Department of Energy, Richland, Washington.

U.S. Department of Energy, Richland Operations Office (DOE-RL). 1994d. N-Springs Expedited Response Action Proposal. DOE/RL-93-23, Rev. 0, prepared by Westinghouse Hanford Company for U.S. Department of Energy, Richland, Washington.

U.S. Department of Energy, Richland Operations Office (DOE-RL). 1996. N-Springs Expedited Response Action Performance Evaluation Report. DOE/RL-95-110, Rev. 0, U.S. Department of Energy, Richland, Washington.

U.S. Department of Energy, Richland Operations Office (DOE-RL). 1997. N-Springs Pump and Treat System Optimization Study. DOE/RL-97-34, Rev. 0, U.S. Department of Energy, Richland, Washington.

U.S. Department of Energy, Richland Operations Office (DOE-RL). 1998a. Screening Assessment and Requirements for a Comprehensive Assessment, Columbia River Comprehensive Impact Assessment. DOE/RL-96-16, Rev. 1, U.S. Department of Energy, Richland, Washington.

U.S. Department of Energy, Richland Operations Office (DOE-RL). 1998b. 100-KR-4 and 100-HR-3 Operable Units Interim Action Performance Evaluation Report. DOE/RL-97-96, Rev. 0, prepared by CH2M Hill Hanford, Inc. for Bechtel Hanford, Inc., U.S. Department of Energy, Richland, Washington.

U.S. Department of Energy, Richland Operations Office (DOE-RL). 1998c. Fiscal Year 1997 Annual Report for the 100-NR-2, 200-UP-1, and 200-ZP-1 Pump and Treat Operations and Operable Units. DOE/RL-98-38, Rev. 0, U.S. Department of Energy, Richland, Washington.

U.S. Department of Energy, Richland Operations Office (DOE-RL). 1999a. Fiscal Year 1998 Annual Report for the 200-UP-1, 200-ZP-1, and 100-NR-2 Pump and Treat Operations and Operable Units. DOE/RL-99-02, Rev. 0, U.S. Department of Energy, Richland, Washington.

U.S. Department of Energy, Richland Operations Office (DOE-RL). 1999b. Groundwater/Vadose Zone Integration Project Summary Description. DOE/RL-98-48, Vol. I, Rev. 0, U.S. Department of Energy, Richland, Washington.

U.S. Department of Energy, Richland Operations Office (DOE-RL). 1999c. Annual Summary Report, February to December 1998, for the 100-HR-3 and 100-KR-4 Pump-and-Treat Operations and Operable Units. DOE/RL-99-13, Rev. 0, U.S. Department of Energy, Richland, Washington.

Van Verst, S. P., C. L. Albin, G. W. Patton, M. L. Blanton, T. M. Poston, A. T. Cooper, and E. J. Antonio. 1998. Survey of Radiological Contaminants in the Near-Shore Environment at the Hanford Site 100-N Reactor Area. PNNL-11933, prepared by the Washington State Department of Health and Pacific Northwest National Laboratory for the U.S. Department of Energy, Richland, Washington. 
Vanderploeg, H. A., D. C. Parzyck, W. H. Wilcox, J. R. Kerchner, and S. V. Kaye. 1975. Bioaccumulation Factors for Radionuclides in Freshwater Biota. ORNL-5002, Oak Ridge National Laboratory, Oak Ridge, Tennessee.

Visser, R. H. 2000. Using Remotely Sensed Imagery and GIS to Monitor and Research Salmon Spawning: A Case Study of the Hanford Reach Fall Chinook (Oncorhynhus tshawytscha). PNNL-13177, Pacific Northwest National Laboratory, Richland, Washington. 


\title{
Appendix A
}

\author{
Monitoring Methods
}




\section{Appendix A}

\section{Monitoring Methods}

\section{A.1 Groundwater Monitoring Wells}

Monitoring wells are the traditional method for obtaining water samples from the aquifer. Their location on the Hanford Site has been dictated by a variety of objectives, from water supply to monitoring contaminants associated with operating facilities and former disposal sites. Wells have recently been installed for the singular purpose of extracting contaminated groundwater for treatment at the surface and for injecting solutions that treat contamination in situ in the subsurface. Construction of wells at the Hanford Site is regulated under the Washington State Administrative Code (WAC-173-160). The annual groundwater monitoring report describes well construction, maintenance, and decommissioning that occurs each year on the Site (Hartman 1999, Section 7.0). Use of the wells is described in a plan that describes an integrated schedule for the numerous users of wells on the Site (Hartman et al. 1998).

\section{A.2 Aquifer Sampling Tubes at River Shoreline}

These small-diameter sampling tubes are installed along the low-water shoreline of the 100 Area and downstream to the Old Hanford Townsite. Methodology development and initial installations took place in fall 1995 at the 100-D/DR Area (Hope and Peterson 1996a). A more comprehensive installation project occurred during September, October, and November 1997 (Peterson et al. 1997). The tube locations are spaced $\sim 300 \mathrm{~m}$ apart. Up to three tubes are installed at each location, and their openings are at various depths in the aquifer.

Sampling results from initial use of the tubes in fall 1997 are available for tritium, gross beta, nitrate, and hexavalent chromium (Peterson et al. 1998). The tube samples showed wide variability in the relative proportions of groundwater and river water, as indicated by the specific conductance of the samples. Subsequent resampling occurred in fall 1998, and the data are published in an Environmental Restoration Contractor technical memorandum (Blumenkranz et al. 1999). A third round of sampling is planned for fall 1999. All available analytical results associated with tube sampling are current being loaded into the HEIS.

The significance of observational data from these tubes is that they represent conditions at locations as close as logistically practical to discharge locations in the river. Data from multiple tube depths help create a three-dimensional characterization of contamination near the river. 


\section{A.3 Riverbank Seepage Sites}

Riverbank seeps are sampled during periods of low-river discharge, which occurs during the late summer and fall months. This is the period when seepage is least influenced by bank storage of river water and, therefore, is most representative of groundwater that discharges into the river. Most samples are analyzed for tritium, which is a good tracer for groundwater movement; gross alpha/gross beta concentration (indicative of strontium-90, technetium-99, and uranium); anions (e.g., nitrate); and metals (e.g., chromium). Riverbank seepage is monitored because it offers a potential pathway for a) direct human exposure to contaminants, and b) entry into the biotic food chain.

Results of riverbank seepage monitoring are reported annually, as part of the Sitewide Environmental Surveillance Project (e.g., Dirkes and Hanf 1998). A 1992 report summarized all riverbank seepage data available at the time and compared them to data from near-river monitoring wells and near-shore river water (Peterson and Johnson 1992).

\section{A.4 Riverbed Sediment Pore Water}

Collecting samples of riverbed sediment pore water is logistically difficult, so routine monitoring is not performed. Several special investigations have taken place using divers to collect samples (Hope and Peterson 1996a, 1996b). The objective for these two field studies was to measure hexavalent chromium concentrations in river substrate that is considered suitable for salmon spawning. Analyses performed included hexavalent chromium, nitrate, and several physical properties. Radionuclides were not included in the analysis, as their presence was not expected.

\section{A.5 References}

Blumenkranz, D. B., W .J. McMahon, and R. F. Raidl. 1999. 100-HR-3 and 100-KR-4 Pump-and-Treat Second Quarter Fiscal Year 1999 Technical Memorandum. Interoffice Memorandum, R.L. Jackson to M. A. Buckmaster, May 1999, Control No. 0510110, prepared by CH2M Hill Hanford, Inc. for Bechtel Hanford, Inc., Richland, Washington.

Dirkes, R. L., and R. W. Hanf (eds.). 1998. Hanford Site Environmental Report for Calendar Year 1997. PNNL-11795, Pacific Northwest National Laboratory, Richland, Washington.

Dirkes, R. L., R.W. Hanf, and T.M Poston (eds.). 1999. Hanford Site Environmental Report for Calendar Year 1998. PNNL-12088, Pacific Northwest National Laboratory, Richland, Washington.

Hartman, M. J. (ed.). 1999. Hanford Site Groundwater Monitoring for Fiscal Year 1998. PNNL-12086, Pacific Northwest National Laboratory, Richland, Washington.

Hartman, M. J., P. E. Dresel, J. P. McDonald, R. B. Mercer, D. R. Newcomer, and E. C. Thornton. 1998. Integrated Monitoring Plan for the Hanford Groundwater Monitoring Project. PNNL-11989, Pacific Northwest National Laboratory, Richland, Washington. 
Hope, S. J., and R. E. Peterson. 1996a. Chromium in River Substrate Pore Water and Adjacent Groundwater: 100-D/DR Area, Hanford Site, Washington. BHI-00778, Rev. 0, prepared by CH2M Hill Hanford, Inc. for Bechtel Hanford, Inc., Richland, Washington.

Hope, S. J., and R. E. Peterson. 1996b. Chromium Concentrations in 100-H Operable Unit Pore Water Within Chinook Salmon Spawning Habitat of the Hanford Reach, Columbia River. BHI-00345, Rev. 0, prepared by CH2M Hill Hanford, Inc. for Bechtel Hanford, Inc., Richland, Washington.

Peterson, R. E,. and V. G. Johnson. 1992. Riverbank Seepage of Groundwater Along the Hanford Reach of the Columbia River, Washington. WHC-EP-0609, Westinghouse Hanford Company, Richland, Washington, 44 pp. plus appendices.

Peterson, R. E., J. V. Borghese, and D. B. Erb. 1998a. Aquifer Sampling Installation Completion Report: 100 Area and Hanford Townsite Shorelines. BHI-01153, Rev. 0, prepared by CH2M Hill Hanford, Inc. for Bechtel Hanford, Inc., Richland, Washington.

Peterson, R. E., K. L. Singleton, and J. V. Borghese. 1997. Description of Work for Installing Aquifer Sampling Tubes Along the 100 Area and Hanford Townsite Shorelines. BHI-01090, Rev. 0, prepared by CH2M Hill Hanford, Inc. for Bechtel Hanford, Inc., Richland, Washington. 


\section{Appendix B}

Uncertainties Associated With Plume Characterizations 


\section{Appendix B}

\section{Uncertainties Associated With Plume Characterizations}

\section{B.1 Uncertainty Associated With Plume Boundaries}

Two principal sources for uncertainty in information on the nature and extent of groundwater contamination result from a) the methods used to depict the area on maps, and b) from how well field observations represent actual conditions in the aquifer.

\section{B.1.1 Methods for Creating Plume Maps}

Plume maps are typically constructed using concentrations measured in samples from groundwater monitoring wells. Lines are drawn to connect observed or inferred points of equal concentration. These contour lines are frequently cited as plume boundaries. Unfortunately, this can be misleading, because the edge of a plume is rarely defined as distinctly as implied by a contour line. The actual boundaries for plumes on the Hanford Site may be highly irregular, with fingerlike fringes. This is because of the highly variable textural and lithologic characteristics of aquifer sediments, which in turn cause variability in groundwater flow paths and rates of flow.

Hydrologists use all available information to infer the shape and extent of a plume. This information includes observed concentrations at specific sampling points, as well as information on the direction and rate of groundwater flow and the location of contaminant sources. After choosing a contour concentration to represent the approximate boundaries of a plume, lines are drawn that provide a subjective representation of plume boundaries.

\section{B.1.2 Representativeness of Field Observations}

The majority of monitoring wells on the Hanford Site have open intervals near the water table, i.e., the uppermost part of the unconfined aquifer. For contaminants whose source is disposal at the surface, this is where contamination is most likely to be found. Because the open interval typically extends for $\geq 3$ meters, the water sample represents an average of the vertical distribution of contamination. At scales such as those related to contaminant entry into the river, this becomes an important consideration.

The direction and rate of groundwater movement may change as the result of fluctuations in river stage in the 100 Areas, and also because of human activities such as pumping from wells. If the change of direction lasts long enough, a plume may move away from a monitoring well, causing a reduction in observed concentrations at that well. This process must be kept in mind when drawing conclusions concerning apparent reductions in plume concentrations. 


\section{B.2 Uncertainty Associated With Plume Movement}

The principal sources for uncertainty in describing or predicting plume movements arise from highly variable hydraulic parameters for the aquifer and uneven distributions for monitoring wells. Changing hydraulic gradients in the unconfined aquifer, which are caused by river level fluctuations, also contribute to uncertainty in motion near the river.

\section{B.2.1 Preferential Pathways}

Groundwater movement through the Hanford Site aquifer is not uniform. Variations in hydraulic characteristics, such as transmissivity, result from the heterogeneous nature of the sediments that make up the aquifer. Sediment heterogeneity is a consequence of the dynamic fluvial environment in which the sediments were deposited. Therefore, groundwater movement characteristics can vary widely over small areas. Water table maps and contaminant distribution maps are smoothed representations of the movement of groundwater.

Where aquifer characteristics are conducive to relatively easy movement of groundwater, a preferential pathway exists. In the Hanford unconfined aquifer, an example would be a former channel of the river that is now buried beneath more recent sediments. Channels tend to fill with coarse sediments that are more transmissive than the adjacent bank and overbank sediments. Groundwater will move preferentially along these channels. Evidence for a former channel extending southeast from the 200 East Area appears in the distribution of radionuclide contamination shown in Figure 2.2. Stratigraphic data from boreholes confirms channel desposits in many areas on the Site. A former river channel is an example of a large-scale preferential pathway.

Smaller scale preferential pathways of natural origin also exist. These may result from differences in the degree of cementation of the sediment, or perhaps fine-scale layering of different types of sedimentary particles. A riverbank seepage site is an example of a smaller-scale preferential pathway. If these features did not exist, seepage would be equally spread along the riverbank.

Finally, preferential pathways are created by human activities. The extensive excavations associated with constructing the reactors and ancillary facilities undoubtedly created preferential pathways, in that the engineered backfill may have significantly different hydraulic properties, i.e., it may be more transmissive than the natural sediments. The excavations created to build the river outfall went down as far as the water table near the river. At several areas, enhanced river bank seepage is observed near the outfall structures.

Monitoring well coverage is not sufficiently dense at all contaminated locations to identify every variation in aquifer properties that would influence the movement of groundwater. Therefore, the estimation or prediction of groundwater movement in areas with sparse or no monitoring wells will contain uncertainty with regard to the actual pathway followed by a contaminant plume. 


\section{B.2.2 Changes in Hydraulic Gradients at the Water Table}

The water level (and discharge) of the river in the Hanford Reach rises and falls daily as a consequence of water management by the dam system on the Columbia River. The change in river elevation is sufficiently great to influence the distribution of hydraulic gradients in the water table within several hundred meters of the river. Methods typically used to estimate the movement of groundwater into the river assume an average gradient toward the river. However, at any given time, the gradient may be directed toward, parallel to, or away from the river. The gradient represents the potential for groundwater to flow.

How much water actually moves under the influence of a particular gradient is determined by the length of time that the gradient exists. Assuming typical rates of one-sixth to one-third meter per day $(0.5$ to 1 foot per day), a changed gradient would have to continue for perhaps a month or two before a plume would be displaced relative to monitoring wells for it to be clearly noticed. Because most monitoring wells are sampled at from quarterly to annual intervals, repositioning of contamination may go undetected if major changes in the water table occur.

Near the river, the gradient may move through a 180-degree direction change daily, so the long-term average gradient is a reasonable estimate when calculating the rate of groundwater movement into the river. When estimating the exposure of sensitive riverbed habitat to the influx of contaminated groundwater, the daily gradient change is a significant factor. The greatest rate of entry into the river occurs during the lowest river stage; during high stage, groundwater may not flow into the river at all. Because some component of river water is always flowing through the riverbed substrate parallel to the river's flow, habitat is alternately exposed to river water and a mixture of river and groundwater during each stage cycle. 


\section{Appendix C}

Overview of Studies on Immuno-Suppression and Exposure to Tritium 


\section{Appendix C}

\section{Overview of Studies on Immuno-Suppression and Exposure to Tritium}

The most sensitive biological endpoint for radiation effects on fish is the $0.2 \mathrm{rad} /$ day (4.0 rad total dose) associated with suppression of antibody levels in fish blood serum. This endpoint was derived from studies that focused on the relationship between the fish bacterial pathogen Flexibacter (= Chondrococcus) columnaris and Columbia River fish, principally salmonids. Early immuno-suppression work was performed at the old 100-F aquatic laboratories at Hanford up until 1970, at which time the aquatic laboratory was moved to the 300 Area. An excellent overview of columnaris studies has been provided by Becker (1990, pp. 206-210, 230). A more technical discussion of these studies can be found in Becker and Fujihara (1978, pp. 68-82).

Salmonids can become infected and die from exposure to columnaris. When exposed, the immune system of fish produced circulating antibodies to the bacteria. It takes about 4 weeks for a fish exposed to natural sources of columnaris to develop a competent immune response (Becker and Fujihara 1978, pp. 66). Mortality in exposed populations of fish drops off at this point. Studies have been performed on the production of antibodies to columnaris in exposed trout. Antibodies are assayed by looking at an agglutination reaction between heat-killed columnaris cells and a series of diluted blood serum. Generally, serum was diluted by a factor of two producing dilutions of 1 to $2040,80,160,320,640,1,280$, 2,560 , and 5,120. The reciprocal of these dilutions is called a titer (i.e., a dilution of 1:160 has a titer of 160). When sufficient antibody is present in the diluted serum, an agglutination reaction occurs resulting in a visible precipitation of antibody-heat-killed columnaris cells. The higher the dilution that yields a positive reaction, the greater the immunity of that fish to columnaris.

Studies of fish exposed to columnaris in Columbia River water indicated that yearling fish maintain a mean baseline titer of about 90 (range 40 to 160) (Becker and Fujihara 1978, pp. 68). Following natural exposure through the summer months, the titers increased to a mean of 209 (range 80 to 320). The time frame of the immune response was further characterized by injecting fish (intraperitoneal, i.p.) with a saline suspension of heat-killed bacteria and with heat-killed bacteria suspended in an adjuvant. An adjuvant is a non-toxic oil that facilitates a prolonged release of the heat-killed bacteria by retarding adsorption by the fish. These studies demonstrated that at 4 weeks post vaccination, antibody titers ranged from 20 to 80 for the saline injections and 40 to 160 in the fish vaccinated with the adjuvant treatment. These data indicate that it takes roughly 4 to 5 weeks for trout, once challenged by the pathogen, to develop sufficient antibody levels to confer immunity to the bacteria. Protection appears to be conferred by antibody levels associated with titers of about 80-100 (Becker and Fujihara 1978, pp. 68-75). 


\section{C.1 Relevance to Radiological Dose Effects: Tritium Exposure}

As a follow-on to the initial work with columnaris, it was observed that trout exposed during the first 20 days of embryogenesis to tritiated water were more susceptible to infection to columnaris that control fish (Strand et al. 1973). These observations ultimately lead to the Ph.D. work of J. A. Strand (Strand 1975). The design of this study had a control treatment with four levels of tritium exposure; $0.04 \mathrm{rad}$, $0.4 \mathrm{rad}, 4.0 \mathrm{rad}$, and $40 \mathrm{rad}$ total dose. Corresponding exposure concentrations of tritium were 0.009 , $0.08,0.7$, and $6.9 \mu \mathrm{Ci} / \mathrm{mL}$, respectively. Each treatment was replicated five times (i.e., the exposed fish were held in five separate concrete ponds with five compartments, one for each treatment and a control. This study demonstrated that trout exposed to a dose of 4 and $40 \mathrm{rad}(0.2 \mathrm{rad} / \mathrm{day}$ and $2.0 \mathrm{rad} / \mathrm{day})$ and suppressed antibody production at 9 and 11 weeks post vaccination when compared to controls. The mean titers of the controls at 11 weeks post vaccination ranged from a low of 1,500 to a high of 2,500 (Becker and Fujihara 1978, pp. 76-77). The mean titers in the $0.2 \mathrm{rad} /$ day dose treatment ranged from about 800 to 1,300 . This laboratory study clearly demonstrated immuno-suppression as manifested by suppressed antibody production at 9 and 11 weeks.

An evaluation of the ecological significance of this work, however, needs to address two factors. One is the level of antibody production that is needed to confer protection to a fish following a natural challenge to columnaris, and the other is the time it takes for that fish to reach that level of antibody production that confers immunity. During the initial 3 to 4 weeks following i.p. injection of heat-killed columnaris, the induction and production of antibodies was similar to the kinetics associated with natural waterborne exposure to viable columnaris. Furthermore, there was no difference between treatments at 3 or 5 weeks; however, in one pond at week five, there was an apparent difference between the control and the high dose $(40 \mathrm{rad})$. Past 5 weeks, the kinetics of the i.p.-injected experimental fish changed radically when compared to naturally exposed fish. Fish that have been exposed to natural sources of columnaris had mean peak antibody titers of about 210 (Becker and Fujihara 1978, pp. 68). Other experiments of trout exposed to columnaris in the water column showed titers ranging from 20 to 320 in juvenile, yearling, and 2-year-old trout. The artificially challenged experimental fish continued to produce antibodies unabated such that levels reached titers of 1,500 to 2,500 in the controls by 11 weeks post vaccination. At this point in time, the immuno-suppressive effect associated with exposure to tritium becomes readily discernible; however, the experimentally induced concentrations of circulating antibody are well beyond the levels associated with naturally conferred immunity. These observations beg the question as to whether the exposures at dose rates of 0.2 and $2.0 \mathrm{rad} /$ day would have an influence on susceptibility to columnaris in fish naturally exposed to the water borne pathogen.

Additional studies were also generated form Strand's (1975) Ph.D. work. The permanence of immuno-suppression was demonstrated by re-challenging the original fish and monitoring antibody production. As was demonstrated with the initial primary challenge, production of antibody was still suppressed at 10 weeks post-vaccination at dose rates of 0.2 and $2.0 \mathrm{rad} / \mathrm{day}$ (Strand et al. 1982).

Studies were also performed to determine if the permanent suppression of immunity was an inheritable defect. The original stocks of fish used in Strand's work were bred within exposure groups to determine if genetic transmission of suppressed immunity could be passed from immuno-compromised parental stock to their $F_{1}$ offspring. The results of the genetic testing were carried out for 11 weeks and 
also a year after the challenge to the $\mathrm{F}_{1}$ generation. The study did not demonstrate the immunosuppressive effect that was demonstrated in the parental stock, suggesting that immuno-suppression was not passed on genetically to the $F_{1}$ offspring. The levels of antibody production that were observed in Strand's original work were not attained in these studies, nor was there any evidence of a possible dosedependent relationship between antibody production and exposure to tritium.

The last study of immuno-suppression in rainbow trout was designed to establish the relationship between gamma exposure and low beta (tritium) exposure using suppression of the immune response in trout as a biological endpoint. Trout embryos were exposed to concentrations of tritium to yield doses over the first 20 days of embryogenesis of $0.0,0.03,0.25$, and $2.5 \mathrm{rad}$ total dose. A corresponding series of trout embryo exposures were conducted in a cobalt- 60 irradiation facility to yield 20 day doses of 0.0 , $0.1,1.0$, and $10 \mathrm{rad} /$ day. Juvenile trout were vaccinated as done in previous studies. Agglutination levels were measured with a micro-agglutination technique. Results of this work were inconclusive. A dosedependent response as demonstrated in the earlier work (Strand 1975) was not observed in the tritium exposed embryos, nor was there a dose-dependent immuno-suppressive response observed in the gammaray-exposed trout embryos. The results of this study were inconclusive.

In this regard, immuno-suppression demonstrated in the columnaris studies present the same dilemma associated with other low-dose radiological effects studies of aquatic organisms conducted in past years. In these studies, the extrapolation of dose to demonstrable, reproducible, and environmentally meaningful results is less than clear.

\section{C.2 References}

Becker, C. D. 1990. Aquatic Bioenvironmental Studies: The Hanford Experience 1944-84. Elsevier, New York.

Becker, C. D., and M. P. Fujihara. 1978. “The Bacterial Pathogen Flexibacter columnaris and its Epizootiology Among Columbia River Fish, a Review and Synthesis.” Monograph No. 2. American Fisheries Society, Washington, D.C.

Strand, J. A., M. P. Fujihara, W. L. Templeton, and E. G. Tangen. 1973. "Suppression of Chondrococcus columnaris immune response in rainbow trout sub-lethally exposed to tritiated water during embryogenesis." Symposium on Radioactive Contamination in the Marine Environment, IAEASm-158/33, International Atomic Energy Agency, Vienna, Austria.

Strand, J. A. 1975. "Suppression of the Primary Immune Response in Rainbow Trout, Salmo gairdneri, Sublethally Exposed to Tritiated Water during Embryogenesis.” Ph.D. Dissertation, University of Washington, Seattle, Washington. [Note: published in the open literature as Strand, J. A., M. P. Fujihara, R. D. Burdett, and T. M. Poston. 1977. "Suppression of the Primary Immune Response in Rainbow Trout, Salmo gairdneri, Sublethally Exposed to Tritiated Water during Embryogenesis." J. Fish. Res. Board. Can. 34:1293-1304.] 
Strand, J. A., M. P. Fujihara, T. M. Poston, and C. S. Abernethy. 1982. "Permanence of Suppression of the Primary Immune Response in Rainbow Trout, Salmo gairdneri, Sublethally Exposed to Tritiated Water during Embryogenesis." Rad. Res. 91:533-541. 


\section{Distribution}

No. of

\section{Copies}

\section{OFFSITE}

L. Albin

Division of Radiation Protection

Washington State Department of Health

P.O. Box 47827

Olympia, WA 98504-7827

M. R. Ault

U.S. Ecology, Inc.

P.O. Box 638

Richland, WA 99352

T. Berkompas

Yakama Nation

P.O. Box 632

Toppenish, WA 98948-0632

M. L. Blazek, Manager

Radioactive Materials Department

Oregon Department of Energy

625 Marion Street, N.E.

Salem, OR 97310

Rick Bond

Washington Department of Ecology

1315 West Fourth Ave.

Kennewick, WA 99336-6018

Clayton Buck

Wanapum

Grant County P.U.D.

30 "C" Street, S.W.

P.O. Box 878

Ephrata, WA 98823
No. of

\section{Copies}

Rex Buck, Jr.

Wanapum

Grant County P.U.D.

30 "C" Street, S.W.

P.O. Box 878

Ephrata, WA 98823

A. Danielson

Washington State Department of Health 5508 Englewood Avenue

Yakima, WA 98908

G. deBruler

Columbia River United

P.O. Box 912

Bingen, WA 98605

J. L. Erickson, Director

Division of Radiation Protection

Washington State Department of Health

P.O. Box 47827, MS-7827

Olympia, WA 98504-7827

R. E. Jaquish

Washington State Department of Health 1232 Vintage Avenue

Richland, WA 99352

Russell Jim, Manager

Environmental Restoration/Waste

Management Program

Yakama Nation

2808 Main Street

Union Gap, WA 98903 
PNNL-13127

No. of

Copies

D. E. Linehan

U.S. Fish and Wildlife Service

P.O. Box 700

Umatilla, OR 97882

Katy Makeig

Waste Science Inc.

1411 Fallswood Drive

Rockville, MD 20854

T. Martin

Hanford Education Action League

1718 W. Broadway, Suite 230

Spokane, WA 99201

D. McBaugh, Head

Division of Radiation Protection

Washington State Department of Health

P.O. Box 47827, MS-7827

Olympia, WA 98504-7827

C. Palmer

Department of Natural Resources

Yakama Nation

P.O. Box 151

Toppenish, WA 98948

Nanci Peters

Yakama Nation

1933 Jadwin Ave., Suite 110

Richland, WA 99352

D. Powaukee

Environmental Restoration/Waste

Management Program

Nez Perce Tribe

P.O. Box 365

Lapwai, ID 83540
No. of

Copies

M. Sampson

Tribal Councilman

Yakama Nation

370 N. Broun Road

Wapato, WA 98951

Stan Sobczyk

Environmental Restoration/Waste

Management Program

Nez Perce Tribe

P.O. Box 365

Lapwai, ID 83540

Patrick Sobotta, Interim Director

Environmental Restoration/Waste

Management Program

Nez Perce Tribe

P.O. Box 365

Lapwai, ID 83540

M. D. Squeochs

Department of Natural Resources

Environmental Program

Yakama Nation

P.O. Box 151

Toppenish, WA 98948

Jo Marie Tessman

Special Sciences and Resources Program

Confederated Tribes of the Umatilla Indian

Reservation

P.O. Box 638

Pendleton, OR 97801

Washington State Department of Ecology

Library, PV-11

P.O. Box 47600

Olympia, WA 98504-7600 
No. of

Copies

J. R. Wilkinson, Manager

Special Sciences and Resources Program

Confederated Tribes of the Umatilla Indian

Reservation

P.O. Box 638

Pendleton, OR 97801

\section{ONSITE}

\section{DOE Richland Operations Office}

K. V. Clarke

A7-75

M. J. Furman

J. B. Hall

R. D. Hildebrand

J. E. Rasmussen

K. M. Thompson (5)

A. C. Tortoso

D. C. Ward

J. H. Zeisloft

DOE Public Reading Room (2)

8 Bechtel Hanford, Inc.

P. G. Doctor

K. R. Fecht

B. H. Ford

K. A. Gano

G. C. Henckel

R. J. Landon

G. W. McNair

D. D. Teel

6 CH2M Hill Hanford, Inc.

J. V. Borghese

W. J. McMahon

R. F. Raidl

V. J. Rohay

L. C. Swanson

S. G. Weiss
No. of

Copies

4 Waste Management Technical Services, Inc., Northwest Operations

L. P. Diediker H6-36

J. J. Dorian H1-13

A. R. Johnson H1-13

C. J. Perkins H1-11

60 Pacific Northwest National Laboratory

E. J. Antonio K3-54

G. R. Bilyard K8-03

L. E. Bisping K6-75

C. A. Brandt K6-85

R. W. Bryce K6-75

A. L. Bunn K6-85

D. D. Dauble K6-85

J. L. Devary K6-96

R. L. Dirkes (5) K6-75

P. E. Dresel K6-96

M. D. Freshley K9-36

J. S. Fruchter K6-96

D. R. Geist K6-85

B. M. Gillespie K6-96

R. W. Hanf K6-75

M. J. Hartman K6-96

V. G. Johnson K6-96

S. P. Luttrell K6-96

B. A. Napier K3-54

D. R. Newcomer K9-96

G. P. O'Connor K6-86

B. E. Opitz K6-75

G. W. Patton K6-75

R. E. Peterson (10) K6-96

T. M. Poston (10) K6-75

K. R. Price K6-75

K. Rhoads K3-54

R. M. Smith K6-96

M. D. Sweeney K6-81

B. A. Williams K6-81

Historical File-T. M. Poston K6-75

Information Release (7) K1-06 